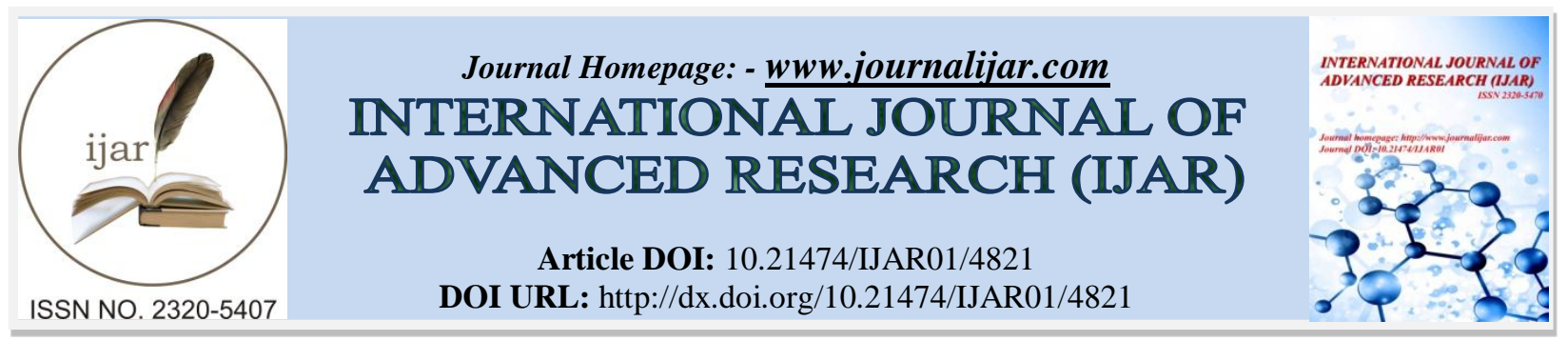

RESEARCH ARTICLE

\title{
DISSERTATION SUBMITTED IN PARTIAL FULFILMENT OF THE REQUIREMENT FOR THE AWARD OF THE DEGREE OF MASTER OF PUBLIC HEALTH.
}

Mohammad Osman Zaki PHARM.D MPH, Dr Ajmal Yadgari MD MPH.

Jodhpur School of Public Health (JSPH), Maulana Azad University Jodhpur, India.

\section{Manuscript Info}

\section{Manuscript History}

Received: 11 May 2017

Final Accepted: 13 June 2017

Published: July 2017

\section{Abstract}

Rational: The public-sector pharmaceutical supply system in Afghanistan has been a collective effort of the Ministry of Public Health $(\mathrm{MoPH})$ and international and national partners to ensure an uninterrupted supply of good-quality, essential medicines to health facilities providing the Basic Package for Health Services (BPHS) and Essential Package for Hospital Services (EPHS). Supplier performance is critical to the procurement process. Monitoring suppliers' performance is one of the World Health Organization's (WHO's) recommended procedures to achieve its strategic objectives of pharmaceutical procurement.

Objective: The objectives of the paper was to apply the identified common criteria for Measuring Pharmaceutical Suppliers' Performance at BPHS/EPHS implementers and Hospitals in Afghanistan.

Method: This study was a cross-sectional survey. In total, 34 organizations were selected for the survey, including 13 government entities, 13 National hospital, 9 INGO, 8 NGO and 1 public private partnership.

Population: The target respondents were the staff in charge of pharmaceutical procurement in all the BPHS/EPHS implementers, government entities, and national hospitals that carry out pharmaceutical procurement.

Time Frame: The study took 24 weeks from the start to the preparation of the first draft report.

Results: In total, 34 organizations were selected for the survey, and $29(85 \%)$ responded to the questionnaire. All 29 organizations (100\%) purchased pharmaceuticals from the local market; in particular, from importers. Of them, four (14\%) also purchased directly from the international market. Twenty organizations (69\%) monitored the performance of their suppliers. Eight (40\%) of those organizations monitoring the performance of their suppliers did so at regular intervals.

Of a total of 61 suppliers, 57 (93\%) local suppliers were registered in Afghanistan, and four (7\%) international suppliers were registered in other countries: one in Ireland, one in Netherlands, and two in India. Fifty-five (90\%) of the 61 suppliers are local importers. Of the 61 
Suppliers, 27 (44\%) only served one organization, and 20 (33\%) only served two organizations.

Of the 14 criteria, Remaining shelf life, Correct products, Correct and packaging, Correct quantities, and Insurance and shipment cost were fully met by at least $90 \%$ of suppliers. Remaining shelf life had the highest overall score, followed by correct quantities, correct products, and Correct and undamaged packaging.

Conclusion and Recommendation: In conclusion, most organizations have been monitoring the performance of their suppliers in various manners, and suppliers' performance was better in delivery services than in product quality. Therefore, there is potential for building a harmonized mechanism among organizations for monitoring suppliers' performance in their procurement management systems, and prequalification of suppliers in Afghanistan's context.

The following are key recommendations for building the capacities of organizations (to monitor the performance of their suppliers) and of suppliers (to improve their performance)

1-Building the capacity and systems of stakeholder organizations

2-Help MoPH and stakeholder organizations to build supplier capacity and systems.

Copy Right, IJAR, 2017, all rights reserved.

$\begin{array}{ll}\text { Acronyms:- } & \\ \text { AISA } & \text { Afghanistan Investment Support Agency } \\ \text { BPHS } & \text { Basic Package for Health Services } \\ \text { CA } & \text { Cluster analysis } \\ \text { CMS } & \text { Central Medical Stores } \\ \text { COPP } & \text { Certificate of Pharmaceutical Product } \\ \text { CPDS } & \text { Coordinated Procurement and Distribution System } \\ \text { DEA } & \text { Data envelopment analysis } \\ \text { EPHS } & \text { Essential Package for Hospital Services } \\ \text { GDP } & \text { Good Distribution Practices } \\ \text { GDPA } & \text { General Directorate of Pharmaceutical Affairs } \\ \text { GMP } & \text { Good Manufacturing Practices } \\ \text { ISO } & \text { International Organization for Standardization } \\ \text { KPI } & \text { Key performance indicators } \\ \text { MoCI } & \text { Ministry of Commerce and Industries } \\ \text { MoPH } & \text { Ministry of Public Health } \\ \text { NGO } & \text { Nongovernmental organization } \\ \text { PRIS } & \text { Pharmaceutical Registration Information System } \\ \text { PSM } & \text { Pharmaceutical supply management } \\ \text { WHO } & \text { World Health Organization }\end{array}$

Introduction:-

In the past decade, Afghanistan's Ministry of Public Health (MoPH) has been implementing the Basic Package for Health Services (BPHS) and Essential Package for Hospital Services (EPHS) with the collective effort of the international and national partners to ensure access to public health services and an uninterrupted supply of goodquality essential medicines. In order to share information and experiences, and to harmonize the management and resources of the pharmaceutical supply management (PSM) systems among BPHS/EPHS implementers, the MoPH established the Coordinated Procurement and Distribution System (CPDS) in 2009.

CPDS conducted a survey to identify the common criteria feasible for implementers to monitor suppliers. Due to CPDS survey (between October and December 2013) 14 criteria were identified. 
The current survey was conducted between September 2016 and February 2017, and used the 14 CPDS identified common criteria to measure the performance of suppliers.

This study was a cross-sectional survey. The method applied was an internal customer satisfaction survey about the suppliers' operational performance in the latest regular purchase on the 14 common criteria which were identified due to CPDS survey through a structured paper questionnaire. Categorical method was applied with rating of criteria meeting status, and Likert scale for overall rating for data collection and data analysis for measuring suppliers' performance. Twenty-nine out of 34 selected organizations participated in the survey.

This survey identified the respondent organizations' operations in monitoring the performance of suppliers, and how the suppliers performed recently according to the respondents' feedback for the selected criteria. The key findings are summarized as follows.

\section{Respondent organizations' operations:-}

- All 29 organizations (100\%) purchased pharmaceuticals from the local market; in particular, from importers. Of them, four (14\%) also purchased directly from the international market.

- Twenty organizations (69\%) monitored the performance of their suppliers.

- Eight (40\%) of those organizations monitoring the performance of their suppliers did so at regular intervals.

- The majority of organizations documented the results of this monitoring in reports (50\%) or checklists (40\%).

- Thirteen (45\%) organizations had only one supplier in their most recent regular procurement prior to the survey; $16(55 \%)$ had between three and 25 suppliers.

- The criterion of Suppliers' licenses was applied by all organizations. The criteria applied by at least $90 \%$ of the organizations were: Shipping correct products, Remaining shelf lives of the received products, Product quality certificates, Compliance in mode and costs of insurance and shipment, and all the criteria regarding delivery.

\section{Suppliers' information and performance:-}

- Of a total of 61 suppliers, 57 (93\%) local suppliers were registered in Afghanistan, and four (7\%) international suppliers were registered in other countries: one in Ireland, one in Netherlands, and two in India.

- Fifty-five (90\%) of the 61 suppliers are local importers.

- Of the 61 suppliers, 27 (44\%) only served one organization, and 20 (33\%) only served two organizations.

- Of the 14 criteria, Remaining shelf life, Correct products, Correct and packaging, Correct quantities, and Insurance and shipment cost were fully met by at least $90 \%$ of suppliers. Remaining shelf life had the highest overall score, followed by correct quantities, correct products, and Correct and undamaged packaging.

- The average suppliers' performance score was 22.26 ( $80 \%$ of overall score). Thirty-five (57\%) suppliers were above average. Two suppliers (S-16 and S-41) received the highest score of 27 (96\% of overall score), and one supplier (S-43) received the lowest score of 11 (39\% of overall score).

- According to the Likert scale rating, eight (13\%) suppliers rated 5-Excellent; most suppliers rated 4-Above Average $(27,44 \%)$ or 3 -Average $(23,38 \%)$. Three suppliers $(5 \%)$ were rated below average and require improvement.

In conclusion, most organizations have been monitoring the performance of their suppliers in various manners, and suppliers' performance was better in delivery services than in product quality. Therefore, there is potential for building a harmonized mechanism among organizations for monitoring suppliers' performance in their procurement management systems, and prequalification of suppliers in Afghanistan's context.

\section{Background and Objectives:-}

The public-sector pharmaceutical supply system in Afghanistan has been a collective effort of the Ministry of Public Health (MoPH) and international and national partners to ensure an uninterrupted supply of good-quality, essential medicines to health facilities providing the Basic Package for Health Services (BPHS) and Essential Package for Hospital Services (EPHS). An assessment conducted in 2008 found that these stakeholders operated their pharmaceutical supply systems differently and with little coordination and information sharing among the stakeholders or with the MoPH (MoPH_GDPA, 2010). In response, the MoPH established the Coordinated Procurement and Distribution System (CPDS) in 2009 to share information and experiences, and to harmonize the management and resources of the pharmaceutical supply management (PSM) systems among the stakeholders. 
CPDS conducted the initial activity ("facilitate the establishment of common criteria for supplier performance based on stakeholders' experiences") in 2014, and identified the most common criteria that BPHS/EPHS implementers, governmental entities, and national hospitals use to monitor the performance of their suppliers. The criteria are listed according to the categories of qualification, product quality, prices and costs, delivery, and communication in Table 1. In this survey to use these criteria to identify suppliers that met the common criteria and to propose feasible criteria that could contribute to the prequalification of the suppliers. This report provides the method and findings for this purpose.

The objectives of this survey are:-

Primary objective:-

To apply the identified common criteria for Measuring Pharmaceutical Suppliers' Performance at BPHS/EPHS implementers and Hospitals in Afghanistan

\section{Secondary objectives:-}

- To identify the suppliers that met the common criteria according to stakeholders' experiences

- To propose feasible criteria that could contribute to the prequalification of the suppliers

Table 1:- Common criteria identified from the CPDS survey for monitoring supplier performance.

\section{Qualification}

1. Providing advance documents according to contract terms: Copies of supporting documents such as licenses, GMP certificate, certificate of pharmaceutical product ${ }^{1}$, bank security, certificate of analysis, etc.

2. Financial viability: Ability to show audited financial statements

3. Qualification to tender or procurement: Registered or licensed in country of origin or Afghanistan, WHO prequalified, or GMP certificated

\section{Product Quality}

4. Providing proof documents about product quality: Such as product certificate or batch certificate with specified quality standards according to contract terms

5. Products passing quality tests upon arrival: Quality control certificate or exemption letter of MoPH Afghanistan

\section{Prices and Costs}

6. Insurance and shipment according to contract financial terms: Such as air or surface shipment, CIF or FOB, etc.

7. Invoice compliance with contract pricing terms: The invoice with the products' prices match the pricing terms in the contract/quotes

\section{Delivery}

8. Meeting delivery time according to the contract terms: Receive consignments on time at the board of entry or warehouse as specified in the contract

9. Shipping correct products: The products should be the same as order (name, strength and dosage form)

10. Delivering the quantities according to the contract terms: Supply right quantities as requested in full or partial shipments as specified in the contract

11. Delivering products that comply with contract terms for remaining shelf life: Upon arrival

12. Providing correct packaging: The packaging of the medicines should be of standard quality to ensure quality of the medicines

13. Providing correct labeling: The required specifications should be printed on the label to guarantee proper use of medicines

Communication

14. Actively update about order status: Provide regular information regarding the status of outstanding orders

\footnotetext{
${ }^{1}$ Certificate of Pharmaceutical Product (COPP) is in the format recommended by WHO; it establishes the status of the pharmaceutical product and of the applicant for the certificate in the exporting country. It is for a single product only since manufacturing arrangements and approved information for different dosage forms and different strengths can vary. WHO/Essential medicines and health products/Model Certificate of pharmaceutical product http://www.who.int/medicines/areas/quality_safety/regulation_legislation/certification/modelcertificate/en/
} 


\section{Literature Review:-}

Procurement is a critical step to ensure the availability of the right products in the right quantities, at the right time, at reasonable prices, and at acceptable standards of quality. Some important factors for a successful procurement include the ability of suppliers to provide the products as described above, to meet customer expectations, and (when relevant) to comply with laws and regulations (Gordon, 2005).

Supplier performance is critical to the procurement process. Monitoring suppliers' performance is one of the World Health Organization's (WHO's) recommended procedures to achieve its strategic objectives of pharmaceutical procurement (WHO, 1999). WHO's Good Distribution Practices (GDP) also recommend that the contract for distributors should include responsibilities of the contractor for measures to avoid the entry of counterfeit medicines into the distribution chain (WHO, 2010). Monitoring or measuring supplier performance may help to reduce the cost of purchasing and increase the overall value of the purchasing (Abdolshah, 2013), and to improve supplier development (which has potential to impact customers financially and competitively) (Gordon, 2005). A case study in the US for a large multinational organization found that using a rating tool to evaluate suppliers' performance resulted in a 2.9-fold reduction in the number of suppliers and a 2.6-fold reduction in the value of inventory held. Reducing the number and improving the quality of suppliers resulted in increased quality, reduced lead-time, and a reduction in the number of errors and defects (Cormican \& Cunningham, 2007).

Hany Salama referred to monitoring supplier's performance as "supplier management" and defined it as "the process by which the buyer of a contracted product manages the relationship with the vendor through metrics ${ }^{2}$ of key milestone performance measures" (Salama, 2005). Some of the measures are objective (such as on-time delivery and quantities delivered) and some are subjective (such as responsiveness or customer satisfaction). These "performance indicators are measurement criteria that may include summary components of the contract or factors that are apart from the contract" (Harton, 2004). Selected or prioritized performance indicators are often referred to as key performance indicators (KPI).

Gordon introduced seven steps to measure suppliers' performance (Gordon, 2005):-

1. Align supplier performance goals with organizational goals and objectives.

2. Determine an evaluation approach.

3. Develop a method to collect information about suppliers.

4. Design and develop a robust assessment system.

5. Deploy a supplier performance assessment system.

6. Give feedback to suppliers on their performance.

7. Produce results from measuring supplier performance.

The above steps provide a guided process of measuring or monitoring suppliers' performance. However, methods vary depending on the capacities of the customers, ranging from applying one or two rudimentary KPIs to more sophisticated data gathering and on-site assessment programs that often require a data-management software package. The data collection methods also vary, including paper questionnaires, web-based questionnaires, extracting data from an existing system, face-to-face interviews, site visits, certification, and third-party standards (such as the ISO certification system ${ }^{3}$ ) (Gordon, 2005) (University of Exeter, n.d.). The aspects of supplier performance that the buyers may want to evaluate include financial health, operational performance metrics, business processes and practices, enabling behaviors or cultural factors, and risk factors. The operational performance metrics cover many areas such as quality, delivery, responsiveness, and financial issues. These metrics can be obtained by extracting information from an existing monitoring system, getting reports from the suppliers, or conducting customer or stakeholder surveys on their satisfaction or feedback about their suppliers (Gordon, 2005) (University of Exeter, n.d.).

\footnotetext{
2 Metrics: Parameters or measures of quantitative assessment used for measurement, comparison or to track performance or production. Analysts use metrics to compare the performance of different companies, despite the many variations between firms. http://www.investopedia.com/terms/m/metrics.asp. Accessed on May 6, 2015.

3 The International Organization for Standardization (ISO) develops and publishes international standards and the standards related to the certification process, which are used by certification bodies. Certification - the provision by an independent body of written assurance (a certificate) that the product, service or system in question meets specific requirements. http://www.iso.org/iso/home/standards/certification.htm. Accessed on May 6, 2015.
} 
There are various methodologies for monitoring, qualifying, and selecting suppliers. The methodologies include categorical methods, data envelopment analysis (DEA), ${ }^{4}$ cluster analysis (CA), ${ }^{5}$ and other complicated techniques that require specific software support (Pal, et al., 2013) (Suárez Bello, 2003). Categorical methods are qualitative models. Suppliers' evaluation is based on historical data and the buyer's experience. After a supplier has been rated on all criteria, the buyer gives an overall rating. The primary advantage of the categorical approach is that it helps structure the evaluation process in a clear and systematic way (Pal, et al., 2013).

Proper structured scorecards are often used to assess the individual supplier's performance and compare the performance of all suppliers (Harton, 2004), and to present the results for supplier selection, corrective actions, or future procurement decisions. The scorecards provide a sum of all KPIs with an overall rating of the suppliers (Harton, 2004). Key steps in developing a rating system include assigning weight points to each criterion or KPI, and developing rating standards or setting targets (Harton, 2004) (Lindsey, n.d.) (Liu, n.d.) (Suárez Bello, 2003). Simple rating methods are also available, such as a checklist with ratings on how well supplier met expectations (Did not meet expectations, Met expectations, Exceeded expectations, or Not applicable) (NC, 2013) or a structured reporting form with indicators listed for a monitor to check (CA, 2008).

Monitoring supplier performance may uncover and remove hidden waste and cost drivers in the supply chain, increase competitiveness, facilitate supplier performance improvement, and help the organization make informed business decisions (Gordon, 2005). A successful procurement process should ensure continued good supplier performance through a formal monitoring system. A cumulative file for each supplier should have copies of registration papers, references, special correspondence, complaints, and other anecdotal supplier information. The information system should track chronologically the number and value of tender contracts awarded, and the value of total purchases from the supplier by year, and performance for each tender (WHO, 1999). In addition, a chronological record of all product-quality complaints, with documentation of the results of follow-up, should be separated but linked to a record that documents all quality assurance tests performed, the reasons, and the results (MSH, 2012).

Monitoring or measuring suppliers' performance is part of the process of supplier management to manage the buyersupplier relationship. "Strategic sourcing" is an exercise in which organizations build a network of contractors and suppliers as business partners to help achieve the goals of both organizations and suppliers (Salama, 2005). It is also part of supply chain risk management, which aims to minimize supply chain risk and secure both the quality and the continuity of supply (PQG, 2010).

Ongeri's report recommended that the central medical stores (CMS) improve communication with suppliers by sharing summarized information with suppliers on their performance and discussing broad areas of mutual concern. Corrective action must be agreed upon and documented, with clear expectations and timelines for addressing the shortcomings. Token awards for good performers may also be considered as a means of appreciating their contribution to the achievement of CMS objectives. The CMS should use the results of the annual supplier performance evaluation as part of the evaluation criteria for future contract awards. (Ongeri, 2013).

\section{Methodology:-}

This study was a cross-sectional survey. It analyzed the organizations' level of satisfaction with the suppliers' operational performance in the latest regular purchase ${ }^{6}$ on the 14 common criteria. The target respondents were the staff in charge of pharmaceutical procurement in all the BPHS/EPHS implementers, government entities, and national hospitals that carry out pharmaceutical procurement. A structured questionnaire (Annex 5) was developed. The questionnaire has three sections: (A) Basic information of the organization, (B) Basic information of the

\footnotetext{
${ }^{4}$ DEA is a classification system that splits suppliers between two categories, 'efficient' or 'inefficient'. Suppliers are judged on two sets of criteria, i.e. outputs and inputs. DEA considers a supplier to have a relative efficiency of $100 \%$ if he produces a set of output factors that is not produced by other suppliers with a given set of input factors. ${ }^{5} \mathrm{CA}$ is a basic method from statistics which uses a classification algorithm to group a number of items which are described by a set of numerical attribute scores into a number of clusters such that the differences between items within a cluster are minimal and the differences between items from different clusters are maximal. This classification is used to reduce a larger set of suppliers into smaller more manag eable subsets.

${ }^{6}$ Regular purchase: planned or non-emergency purchase through any of the procurement methods (open tender, restricted tender, request for quotations, or direct purchase).
} 
supplier, and (C) How the supplier met the 14 common criteria. The response for section $\mathrm{C}$ has four options: Fully met, Partly met, Did not meet, and Don't know. A data collection manual was developed with the questionnaire and was used to train data collectors. Data collection was performed in September 2016 and February 2017. Each questionnaire was administered and completed by a pair of data collectors at an organization through physical interviews with the staff in charge of pharmaceutical procurement for the organization, and verification of required documents provided by the organization.

In total, 34 organizations were selected for the survey, and $29(85 \%)$ responded to the questionnaire; respondents included $15(52 \%)$ government entities and $14(48 \%)$ international and national nongovernmental organizations (NGOs). Table 2 indicates the types of respondents and their response rates; respondents are listed in Annex 1.

Table 2:- Responding rates for the survey

\begin{tabular}{|c|c|c|}
\hline Organization types & $\#(\%)$ received the questionnaire & \# (\%) responded to the questionnaire \\
\hline Government entity & $3(9 \%)$ & $2(7 \%)$ \\
\hline National hospitals & $13(38 \%)$ & $13(45 \%)$ \\
\hline International NGO & $9(26 \%)$ & $7(24 \%)$ \\
\hline National NGO & $8(24 \%)$ & $6(21 \%)$ \\
\hline Other* & $1(3 \%)$ & $1(3 \%)$ \\
\hline Total: & $34(100 \%)$ & $29(100 \%)$ \\
\hline Overall response rate: & \multicolumn{2}{|c|}{$\mathbf{2 9 / 3 4 ( 8 5 \% )}$} \\
\hline
\end{tabular}

* Public private partnership

While cleaning the data, several steps were performed to verify suppliers' basic information. The suppliers' English names and registration status were verified against the records in the Pharmaceutical Registration Information System (PRIS). GDPA provided clarifying information on suppliers' names and registration status for those suppliers that were not found in the PRIS. For those suppliers that could not be verified through PRIS and GDPA, further clarification was carried out by cross checking the suppliers' names in Dari and English translation, and rechecking their licenses with respondents' help to confirm suppliers' names and registration status.

The cleaned data were analyzed using Excel pivot tables. In section A and B of the questionnaire, the results are presented in numbers and percentage. In section $\mathrm{C}$, categorical method was applied with rating of criteria meeting status, and Likert scale for overall rating for data collection and data analysis. This method was adopted and modified from Pal, North Carolina, and Lindsey's literature (Pal, et al., 2013) (NC, 2013) (Lindsey, n.d.). In section $\mathrm{C}$, regarding how the suppliers met the criteria, there were four options for answers: Fully met, Partly met, Did not meet, and Don't know. The respondents answered based on their level of satisfaction according to the requests to the suppliers in the procurement contracts, or experiences if not stated in the contracts, for each criterion.

\section{Scoring Methods:-}

The respondents' level of satisfaction about the suppliers for each criterion was scored in four grades: "2" for Fully met, "1" for Partly met, "-1" for Did not meet, and "0" for Don't know. The highest score for each criterion is 2 and the lowest is -1 . The sum of the scores for all criteria was the numerator; the maximum score for all criteria was the denominator. Each supplier's score was presented as percentage of maximum score. Then adapted and applied Lindsey's recommendation for rating the suppliers' performance using Likert scale follows (Lindsey, n.d.) -

- $\quad$ Rating of $5=90 \%$ to $100 \%$ (Excellent)

- Rating of $4=80 \%$ to $89 \%$ (Above Average)

- $\quad$ Rating of $3=60 \%$ to $79 \%$ (Average)

- Rating of $2=40 \%$ to $59 \%$ (Needs Improvement)

- $\quad$ Rating of $1=0 \%$ to $39 \%$ (Unacceptable)

The results will be presented in three areas, including how the organizations applied the criteria, the suppliers' overall performance in each criterion, and suppliers' performance ratings in two ways: performance based on their responses to the requests in the contract terms, and overall performance, regardless of whether the criteria were requested in the contract terms. 


\section{Ethical Considerations:-}

Due to ethical considerations, the suppliers' names are replaced by serial numbers according to the alphabetical order of their English names in this report. Only the participating organizations and GDPA are able to access the results with suppliers' names.

\section{Limitations:-}

There were some limitations in this survey:-

- Due to time constraints, some of the data collectors were not able to verify all the documents at the visited sites. As such, they relied on the respondents' best knowledge to respond to the questionnaire.

- This survey did not differentiate procurement methods (open tender, restricted tender, request for quotations, or direct purchase). Those organizations that only purchased from one supplier might have individual bias toward that supplier. Also, depending on the procurement method, some of the criteria become more or less important.

\section{Findings:-}

The survey findings are presented in three sections: respondents' procurement markets and systems in monitoring suppliers' performance, suppliers' basic information, and evaluating suppliers' performance according to common criteria.

\section{Respondents' Procurement Markets and Systems in Monitoring Suppliers' Performance:- Procurement Markets:-}

In this survey, procurement markets are classified into local and international markets. In-country purchases from local manufacturers or local importers by the responding organizations were considered purchasing from local market. Importing pharmaceuticals directly from other countries by the responding organizations was considered purchasing from international market. This survey found that all 29 of the respondents purchase pharmaceuticals from the local market. Of them, four (14\%) also purchase from the international market (Table 3); the remaining 25 $(86 \%)$ purchase only from the local market.

Table 3:- Types of procurement markets of the respondents.

\begin{tabular}{|c|c|c|c|}
\hline Organization type & $\#(\%)$ procure from local market only & $\begin{array}{c}\text { \# (\%) procure from local and } \\
\text { internat'l markets }\end{array}$ & Total \\
\hline Government entities & $1(50 \%)$ & $1(50 \%)$ & 2 \\
\hline National hospitals & $13(100 \%)$ & 0 & 13 \\
\hline International NGOs & $5(71 \%)$ & $2(29 \%)$ & 7 \\
\hline National NGOs & $6(100 \%)$ & 0 & 6 \\
\hline Other & 0 & $1(100 \%)$ & 1 \\
\hline Total: & $25(86 \%)$ & $4(14 \%)$ & 29 \\
\hline
\end{tabular}

\section{Monitoring Suppliers' Performance by the Organizations:-}

This section presents the results about whether the organizations monitor suppliers' performance, and, if they do, the frequency and documentation methods.

Of the 29 respondents, 20 (69\%) reported that they monitor suppliers' performance; seven (24\%) reported they did not, and two (7\%) were not sure whether their suppliers' performance was monitored. Figure 1 shows the results, by organization type. Of the 20 respondents that monitored suppliers' performance, most were national hospitals (40\%) and international NGOs (35\%). However, all seven international NGOs monitored suppliers' performance. 
Figure 1:- Monitoring suppliers' performance, by organization type

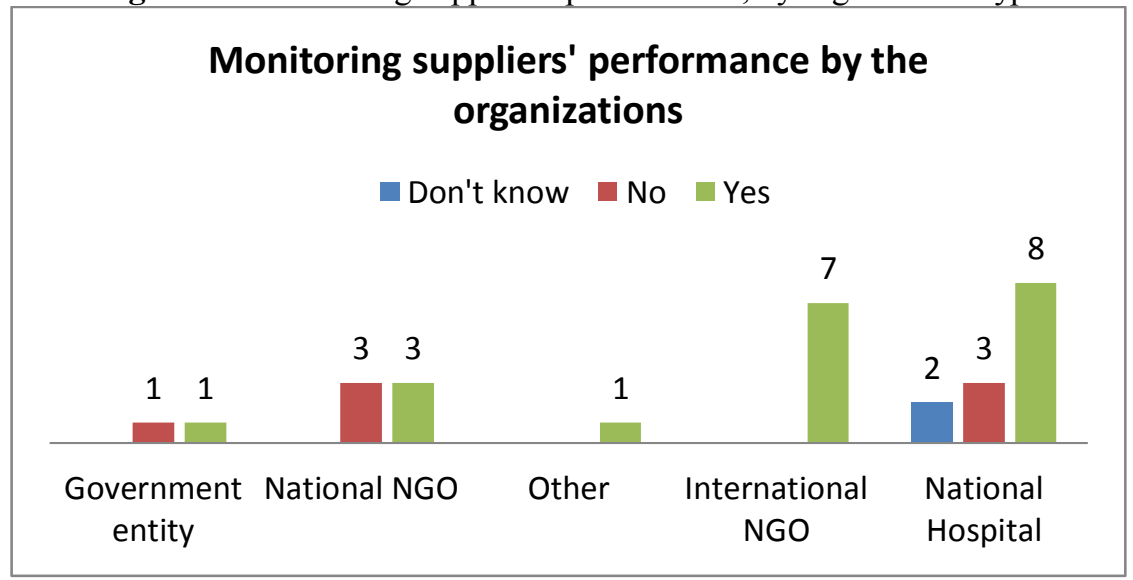

Regarding the frequency with which organizations monitor suppliers' performance, most organizations (60\%) did not have regular monitoring intervals, 20\% monitored quarterly, and 15\% annually (Figure 2). Table 4 presents monitoring frequency by organization type.

Figure 2:- Frequency of monitoring suppliers' performance $(\mathrm{N}=20)$

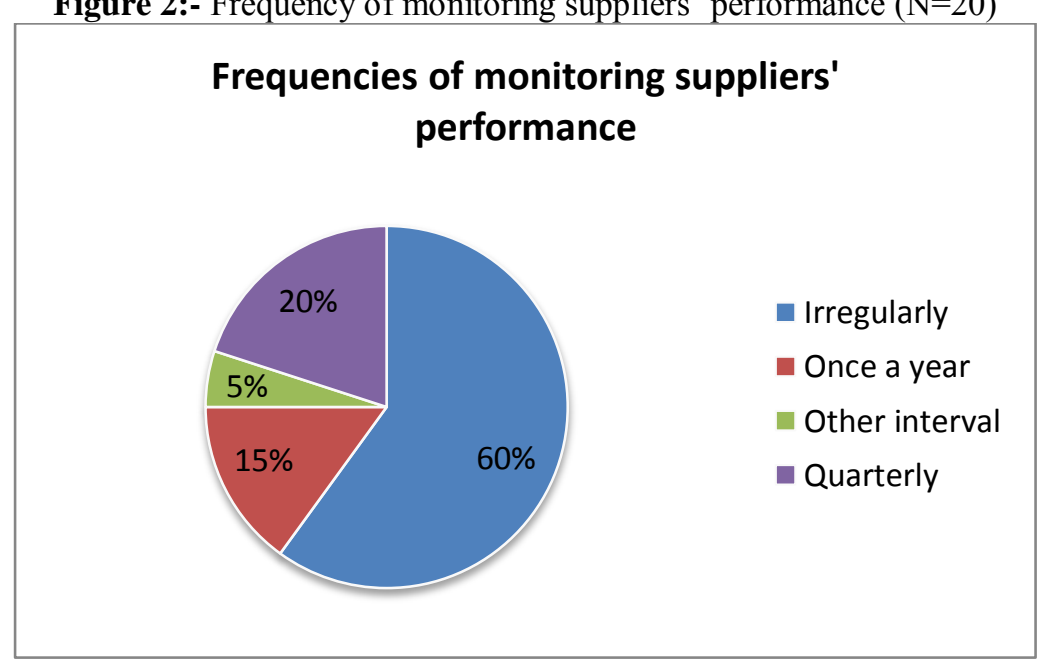

Table 4:- Frequency of monitoring suppliers' performance, by organization type.

\begin{tabular}{|l|l|l|l|l|l|}
\hline \multicolumn{1}{|c|}{ Organization type } & Quarterly & Annually & Irregularly & $\begin{array}{c}\text { Other, or unknown } \\
\text { interval }\end{array}$ & \multicolumn{1}{|c|}{ Total } \\
\hline Government entity & & 1 & & & $1(5 \%)$ \\
\hline National hospitals & & & 8 & & $8(40 \%)$ \\
\hline International NGO & 2 & & 4 & 1 & $7(35 \%)$ \\
\hline National NGO & 2 & 1 & & & $3(15 \%)$ \\
\hline Other & & 1 & & & $1(5 \%)$ \\
\hline Total: & $4(20 \%)$ & $3(15 \%)$ & $12(60 \%)$ & $1(5 \%)$ & $20(100 \%)$ \\
\hline
\end{tabular}

Organizations used various ways to document suppliers' performance, including reports, checklists, and scorecards. Table 5 shows that $50 \%$ of the organizations document supplier performance in reports, followed by checklists $(40 \%)$, and scorecards $(10 \%)$. 
Table 5:- Documentation methods about suppliers' performance by type of organizations

\begin{tabular}{|c|c|c|c|c|}
\hline Organization type & Reports & Checklists & Scorecards & Total \\
\hline Government entity & & 1 & & $1(5 \%)$ \\
\hline National hospitals & 5 & 3 & & $8(40 \%)$ \\
\hline International NGO & 3 & 4 & & $7(35 \%)$ \\
\hline National NGO & 2 & & 1 & $3(15 \%)$ \\
\hline Other & & & 1 & $1(5 \%)$ \\
\hline Total: & $10(50 \%)$ & $8(40 \%)$ & $2(10 \%)$ & $20(100 \%)$ \\
\hline
\end{tabular}

\section{Suppliers' Basic Information:-}

This section describes the background of the suppliers identified in this survey, including country of origin, type of supplier, and registration status.

This survey identified 61 suppliers from the most recent regular procurement of the 29 organizations. The "most recent regular procurement" refers to the most recent, non-emergency procurement that occurred prior to the survey interview, regardless of the organization's procurement methods. Of the 61 suppliers, 57 (93\%) are local suppliers and four (7\%) are international suppliers. The international suppliers are based in India (2), Ireland (1), and Netherlands (1). The results about types of suppliers indicate that $90 \%$ of them are importers; the rest are local manufacturers, importers and local manufacturers, international manufacturers, and international wholesalers (Table $6)$.

Table 6:- Types and numbers of suppliers.

\begin{tabular}{|l|l|l|l|l|l|}
\hline Importer & $\begin{array}{l}\text { Local } \\
\text { manufacturer }\end{array}$ & $\begin{array}{l}\text { Importer and local } \\
\text { manufacturer }\end{array}$ & $\begin{array}{l}\text { International } \\
\text { manufacturer }\end{array}$ & $\begin{array}{l}\text { International } \\
\text { wholesaler }\end{array}$ & Total \\
\hline $55(90 \%)$ & $1(2 \%)$ & $1(2 \%)$ & $2(3 \%)$ & $2(3 \%)$ & $61(100 \%)$ \\
\hline
\end{tabular}

In Afghanistan importers are supposed to register with the Ministry of Commerce and Industries (MoCI) with the note of importing medicines and medical supplies approved by MoPH/GDPA. The local manufacturers are supposed to register with MoPH and Afghanistan Investment Support Agency (AISA). This survey found that all the 57 local suppliers were registered in Afghanistan; all four international suppliers were not.

\section{Evaluating Suppliers' Performance According to the Common Criteria:-}

In this section, suppliers are mapped with the organizations, and are evaluated by the respondents using the 14 common criteria. The organizations' use of the criteria is also presented.

\section{Mapping the Suppliers and Organizations:-}

Since the suppliers' performance was based on the participating organizations' levels of satisfaction, mapping the suppliers with the organizations will be helpful for interpreting the results. Table 7 and Table 8 summarize the mapping results. The detailed mapping results are presented in Annex 2.

Table 7 shows that 13 (45\%) organizations had only one supplier in their most recent regular procurement, 13 (45\%) had between three and seven suppliers, and only three (10\%) organizations reported more than 10 suppliers. Table 8 shows that, of 61 suppliers, 27 (44\%) were reported by only one organization, and 20 (33\%) were reported by only two organizations. Thus the majority of suppliers in this survey were only evaluated by one or two customers.

Table 7:- Number of organizations reporting on corresponding number of suppliers.

\begin{tabular}{|l|l|l|l|l|l|l|l|l|l|l|}
\hline Total & 1 & 3 & 4 & 5 & 6 & 7 & 12 & 23 & 25 & - \\
\hline \# of suppliers & 13 & 4 & 1 & 5 & 1 & 2 & 1 & 1 & 1 & 29 \\
\hline $\begin{array}{l}\text { \# of organizations reporting } \\
\text { on the above \# of suppliers }\end{array}$ & & & & & & & & & \\
\hline
\end{tabular}


Table 8:- Number of suppliers serving corresponding number of organizations.

Total

\begin{tabular}{|l|l|l|l|l|l|l|l|l|l|}
\hline \# of organizations & 1 & 2 & 3 & 4 & 5 & 6 & 8 & 9 & - \\
\hline $\begin{array}{l}\text { \# of suppliers serving the above } \\
\text { \# of organizations }\end{array}$ & 27 & 20 & 6 & 3 & 1 & 1 & 1 & 2 & 61 \\
\hline
\end{tabular}

Application of Common Criteria by Organizations:-

Since there is no standardized system for monitoring suppliers' performance, each organization may have its own criteria based on its priority interest and capacity in monitoring or evaluating suppliers. Twenty organizations monitored suppliers' performance, but all 29 participating organizations responded to the questionnaire since the questions are general to any procurement contracts. The results are presented in Table 9 (which is based on the responses to this question).

In Table 9, the most applied criterion of all the organizations is suppliers' license either for local and country of origin (a sub-criterion in criteria 1 and 3), shipping correct products (criterion 9), and the remaining shelf lives of the received products (criterion 11). Other criteria that were applied by at least $90 \%$ of the organizations are product quality certificates (a sub-criterion in criteria 1 and 5), compliance in mode and costs of insurance and shipment (criterion 6), and all the criteria regarding delivery (criteria 8-13). The WHO prequalification certificate was the least-requested sub-criterion and only applied by one organization.

Table 9:- Application of the common criteria by the organizations $(\mathrm{N}=29)$.

\begin{tabular}{|c|c|c|}
\hline Criteria & $\begin{array}{c}\text { Sub-criteria or description } \\
\text { of the criteria }\end{array}$ & $\begin{array}{l}\text { Applied by \# and \% of } \\
\text { organizations }(\mathrm{N}=29)\end{array}$ \\
\hline \multicolumn{3}{|c|}{ Qualification } \\
\hline \multirow{5}{*}{$\begin{array}{l}\text { 1. Providing advance documents } \\
\text { according to contract terms }\end{array}$} & Bank security & $23(79 \%)$ \\
\hline & Certificate of analysis & $28(97 \%)$ \\
\hline & $\begin{array}{l}\text { Certificate of pharmaceutical } \\
\text { product (CoPP) }\end{array}$ & $19(66 \%)$ \\
\hline & $\begin{array}{c}\text { Good manufacturing } \\
\text { practices (GMP) certificate }\end{array}$ & $17(59 \%)$ \\
\hline & Supplier's license & $29(100 \%)$ \\
\hline 2. Financial viability & $\begin{array}{l}\text { Ability to show audited } \\
\text { financial statements }\end{array}$ & $24(83 \%)$ \\
\hline \multirow{4}{*}{$\begin{array}{l}\text { 3. Qualification to tender or } \\
\text { procurement }\end{array}$} & GMP certificate & $16(55 \%)$ \\
\hline & $\begin{array}{c}\text { Supplier's license, } \\
\text { Afghanistan }\end{array}$ & $29(100 \%)$ \\
\hline & $\begin{array}{c}\text { Supplier's license, country of } \\
\text { origin (international } \\
\text { suppliers) }\end{array}$ & $3(100 \%)^{*}$ \\
\hline & $\begin{array}{c}\text { WHO prequalification } \\
\text { certificate }\end{array}$ & $1(3 \%)^{*}$ \\
\hline \multicolumn{3}{|c|}{ Product Quality } \\
\hline \multirow{2}{*}{$\begin{array}{l}\text { 4. Providing proof documents about } \\
\text { product quality }\end{array}$} & Batch certificate & $21(72 \%)$ \\
\hline & Product certificate (CoPP) & $25(86 \%)$ \\
\hline \multirow[t]{2}{*}{$\begin{array}{l}\text { 5. Products passing quality tests upon } \\
\text { arrival }\end{array}$} & $\begin{array}{c}\text { MoPH exemption letter for } \\
\text { quality test }\end{array}$ & $5(17 \%)$ \\
\hline & $\begin{array}{l}\text { Quality certificates issued by } \\
\text { MoPH QC lab }\end{array}$ & $28(97 \%)$ \\
\hline \multicolumn{3}{|c|}{ Prices and Costs } \\
\hline $\begin{array}{l}\text { 6. Insurance and shipment according } \\
\text { to contract financial terms }\end{array}$ & $\begin{array}{l}\text { Mode and costs of insurance } \\
\text { and shipment according to } \\
\text { contract terms }\end{array}$ & $26(90 \%)$ \\
\hline $\begin{array}{l}\text { 7. Invoice compliance with contract } \\
\text { pricing terms }\end{array}$ & $\begin{array}{l}\text { Invoice product prices } \\
\text { matches contract prices }\end{array}$ & $23(79 \%)$ \\
\hline \multicolumn{3}{|c|}{ Delivery } \\
\hline 8. Meeting delivery time according to & Make consignments available & $28(97 \%)$ \\
\hline
\end{tabular}




\begin{tabular}{|c|c|c|}
\hline the contract terms & $\begin{array}{c}\text { on time at the board of entry } \\
\text { or warehouse as specified in } \\
\text { the contract }\end{array}$ & $29(100 \%)$ \\
\hline 9. Shipping correct products & $\begin{array}{c}\text { Deliver correct products as } \\
\text { per contract/order } \\
\text { specifications }\end{array}$ & $28(97 \%)$ \\
\hline $\begin{array}{c}\text { 10. Delivering the quantities according } \\
\text { to the contract terms }\end{array}$ & $\begin{array}{c}\text { Deliver right quantities by the } \\
\text { end of the timeline specified } \\
\text { in the contract terms }\end{array}$ & $29(100 \%)$ \\
\hline $\begin{array}{c}\text { 11. Delivering products that comply } \\
\text { with contract terms for remaining } \\
\text { shelf life }\end{array}$ & $\begin{array}{c}\text { All items' remaining shelf } \\
\text { lives met the requirement }\end{array}$ & $27(93 \%)$ \\
\hline 12. Providing correct packaging & $\begin{array}{c}\text { Correct packaging as required } \\
\text { and without damage upon } \\
\text { arrival }\end{array}$ & \\
\hline 13. Providing correct labeling & $\begin{array}{c}\text { Correct labeling as required } \\
\text { with all recognizable } \\
\text { information }\end{array}$ & $26(90 \%)$ \\
\hline 14. Actively update about order status & $\begin{array}{c}\text { Provided updates about the } \\
\text { delivery status of the } \\
\text { outstanding orders }\end{array}$ & \\
\hline
\end{tabular}

* Only four organizations reported purchasing from international suppliers.

Criteria Meeting Status by the Suppliers:-

To present the overall criteria meeting results, we took into account that different buyer organizations might make different requests of the same supplier, and one supplier's responses to multiple buyers might also differ. Therefore, this analysis considers each organization-supplier interaction individually. The total was calculated by multiplying the number of organizations by the number of suppliers reported on by each organization, and adding those results into one "grand total organization-supplier interactions (134)" (Table 10).

Table 10:- Total organization-supplier interactions.

\begin{tabular}{|l|l|l|l|l|l|l|l|l|l|l|}
\hline & Grand total \\
\hline Number of suppliers reported by organizations (A) & 1 & 3 & 4 & 5 & 6 & 7 & 12 & 23 & 25 & - \\
\hline $\begin{array}{l}\text { Number of organizations that reported the above } \\
\text { number of suppliers (B) }\end{array}$ & 13 & 4 & 1 & 5 & 1 & 2 & 1 & 1 & 1 & 29 \\
\hline Total organization-supplier interactions (A*B) & $\mathbf{1 3}$ & $\mathbf{1 2}$ & $\mathbf{4}$ & $\mathbf{2 5}$ & $\mathbf{6}$ & $\mathbf{1 4}$ & $\mathbf{1 2}$ & $\mathbf{2 3}$ & $\mathbf{2 5}$ & $\mathbf{1 3 4}$ \\
\hline
\end{tabular}

The results of meeting criteria by the suppliers are analyzed in two ways: whether the criterion was met when it was mentioned in the purchase order or contract terms as a requirement or expectation; and whether a criterion was met, regardless of whether it was requested in the purchase order or a contract. The results are described below.

Table 11 presents the results about whether the criterion was met when it was requested in the purchase order or contract terms. Criteria 1, 3, and 11 were requested by all organizations to all of their suppliers. Criteria 2 (financial viability) and 14 (active update) were the least requested. The suppliers were able to respond to the requests fully for criteria 6 (shipment/insurance costs), 7 (price compliance), 9 (correct products), 11 (remaining shelf lives), 12 (packaging), and 13 (labeling). However, only 19\% for criterion 3 (qualification for tender) and 17\% for criterion 5 (quality) were fully met. Figure 3 provides a graphic view of the results presented in Table 11. 
Table 11. Summary of the criteria meeting status based on the requests in the contract terms

\begin{tabular}{|c|c|c|c|c|c|c|c|c|}
\hline \multirow[t]{2}{*}{ Criteria } & \multicolumn{2}{|c|}{$\begin{array}{l}\text { Requested } \\
(\mathbf{N}=134)\end{array}$} & \multicolumn{2}{|c|}{$\begin{array}{l}\begin{array}{l}\text { Fully } \\
(\mathrm{N}=\mathrm{nr})\end{array} \\
\text { met }\end{array}$} & \multicolumn{2}{|c|}{$\begin{array}{l}\text { Partly met } \\
(\mathrm{N}=\text { nr) }\end{array}$} & \multicolumn{2}{|c|}{$\begin{array}{l}\text { Not met } \\
(\mathrm{N}=\mathrm{nr})\end{array}$} \\
\hline & nr & $\%$ & $\mathbf{n}$ & $\%$ & $\mathbf{n}$ & $\%$ & $\mathbf{n}$ & $\%$ \\
\hline $\begin{array}{l}\text { 1. Providing advance documents according to contract } \\
\text { terms* }\end{array}$ & 134 & $100 \%$ & 85 & $63 \%$ & 49 & $37 \%$ & & \\
\hline 2. Financial viability & 81 & $60 \%$ & 76 & $94 \%$ & & & 5 & $6 \%$ \\
\hline 3. Qualification to tender or procurement* & 134 & $100 \%$ & 25 & $19 \%$ & 109 & $81 \%$ & & \\
\hline 4. Providing proof documents about product quality* & 129 & $96 \%$ & 81 & $63 \%$ & 48 & $37 \%$ & & \\
\hline 5. Products passing quality tests upon arrival* & 126 & $94 \%$ & 22 & $17 \%$ & 104 & $83 \%$ & & \\
\hline $\begin{array}{l}\text { 6. Insurance and shipment according to contract financial } \\
\text { terms }\end{array}$ & 121 & $90 \%$ & 121 & $100 \%$ & & & & \\
\hline 7. Invoice compliance with contract pricing terms & 117 & $87 \%$ & 117 & $100 \%$ & & & & \\
\hline 8. Meeting delivery time according to the contract terms & 127 & $95 \%$ & 119 & $94 \%$ & 8 & $6 \%$ & & \\
\hline 9. Shipping correct products & 130 & $97 \%$ & 130 & $100 \%$ & & & & \\
\hline 10. Delivering the quantities according to the contract terms & 131 & $98 \%$ & 124 & $95 \%$ & 7 & $5 \%$ & & \\
\hline $\begin{array}{l}\text { 11. Delivering products that comply with contract terms for } \\
\text { remaining shelf life }\end{array}$ & 134 & $100 \%$ & 134 & $100 \%$ & & & & \\
\hline 12. Providing correct packaging & 126 & $94 \%$ & 126 & $100 \%$ & & & & \\
\hline 13. Providing correct labeling & 116 & $87 \%$ & 116 & $100 \%$ & & & & \\
\hline 14. Actively update about order status & 80 & $60 \%$ & 74 & $93 \%$ & 6 & $8 \%$ & & \\
\hline
\end{tabular}

* These criteria have multiple sub-criteria. The figure of "Requested (nr)" represents the number of which at least one sub-criterion was requested for such criterion.

Figure 3:- Criteria meeting status based on the requests in the contract terms (C: criterion)

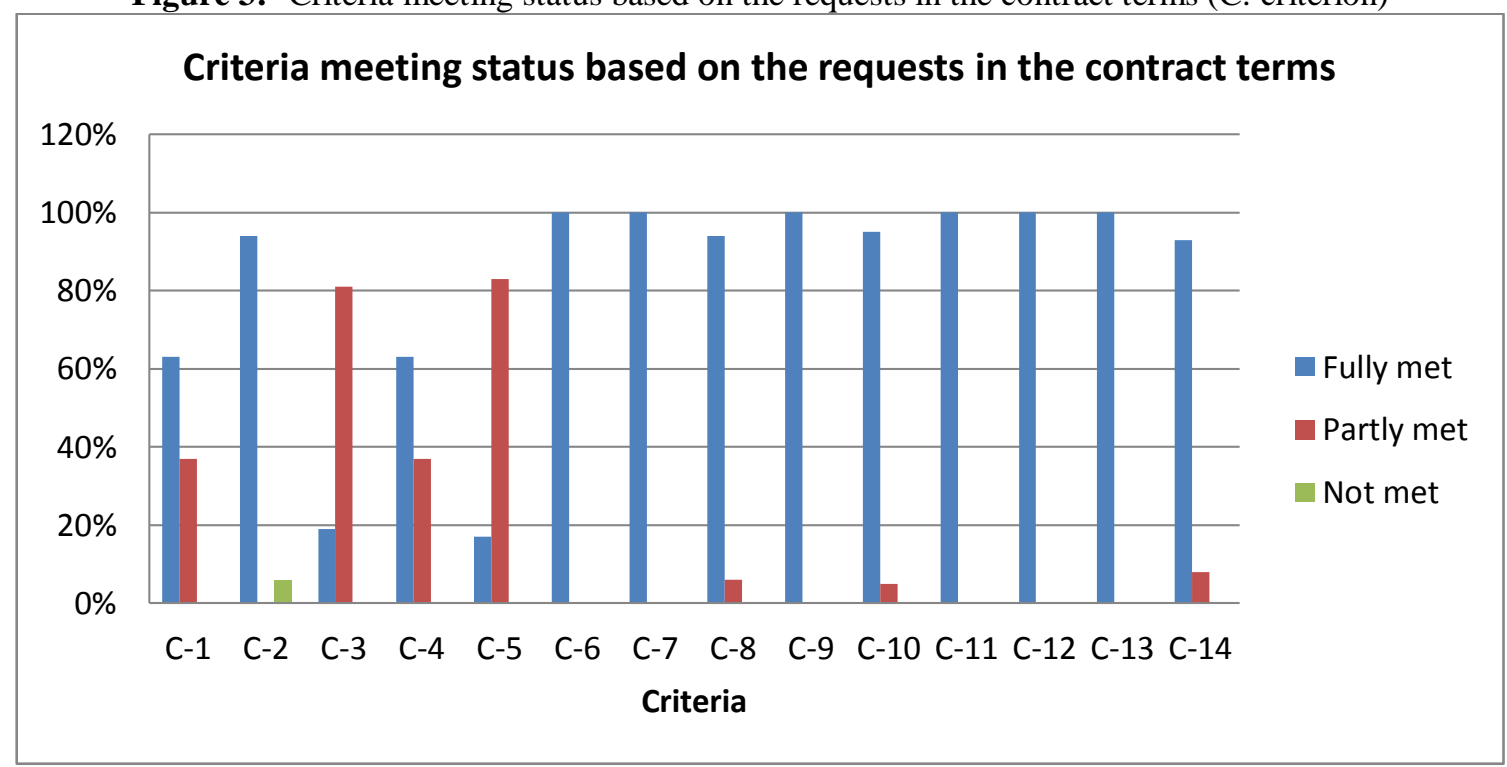

Using the score method described in the Methodology section, suppers' overall scores for each criterion are presented in Figure 4. The average score was 90\%. The criteria for delivery and communication (criteria 6-14) gained higher satisfaction than those related to qualification and product quality (criteria 1,3,4, and 5). The satisfaction on criterion 2 (financial viability) was marginally above the average score. Criteria 3 (qualification to tender) and 5 (product quality) were the least satisfied. 
Figure 4:- Suppliers' overall scores for each criterion based on the responses to the requests in the contract terms.

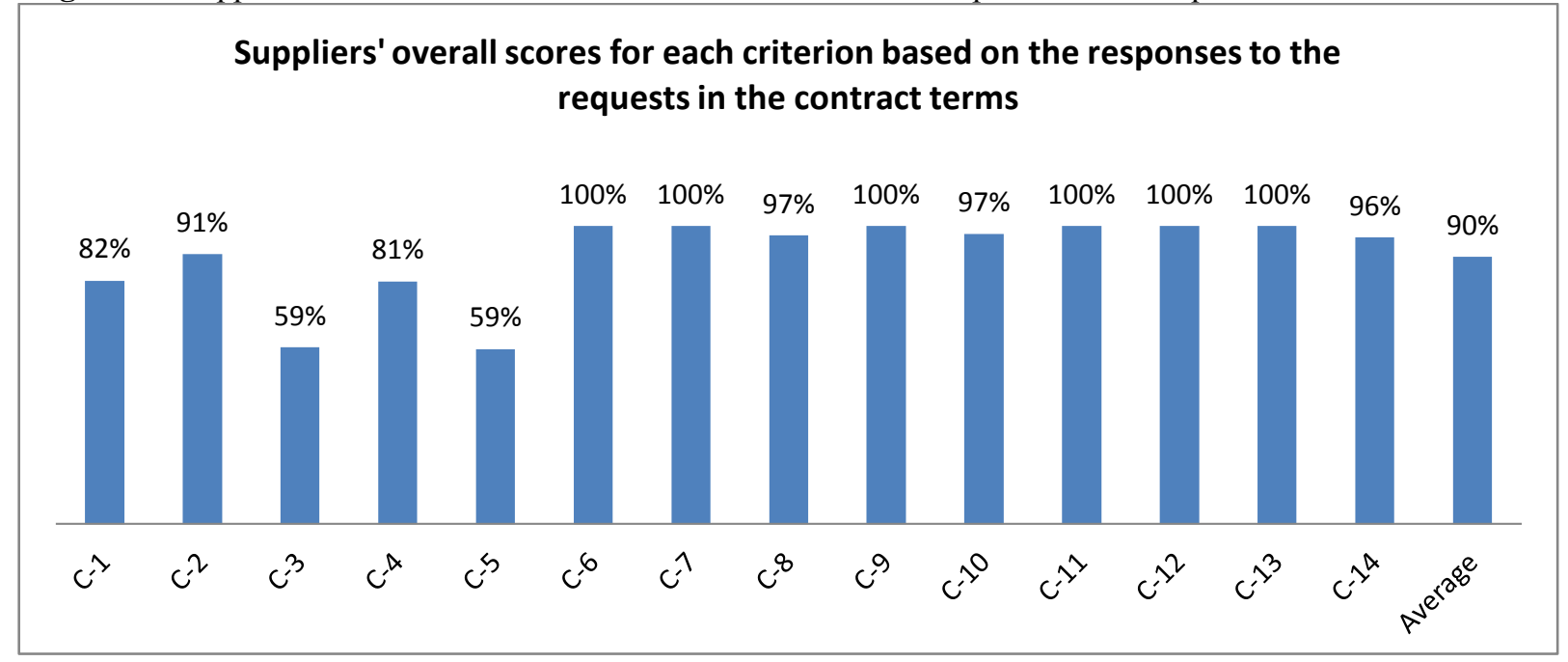

Table 12 summarizes the results about whether a criterion was met, regardless of whether it was mentioned in the purchase order or a contract as a requirement or expectation. All organizations (100\%) were satisfied by all the suppliers for criterion 11 (remaining shelf lives), 97\% were satisfied for criterion 9 (correct products), 94\% for criterion 12 (packaging), 93\% for criterion 10 (quantities), and 90\% for criterion 6 (shipment/insurance costs). The criteria that were least fully met were 19\% for criterion 3 (qualification to tender) and 16\% for criterion 5 (quality certificates); these were mostly partly met ( $81 \%$ and $78 \%$, respectively). There was $6 \%$ dissatisfaction about quality (criterion 5). Criterion 14 received the highest un-satisfaction (30\%), which elaborated that the organizations expected suppliers to proactively communicate about the delivery status of orders. Figure 4 provides a graphic view of the results presented in Table 12.

Table 12:- Summary of the criteria meeting status by grand total organization-supplier $(\mathrm{N}=134)$.

\begin{tabular}{|l|l|l|l|l|l|l|l|l|}
\hline \multirow{2}{*}{ Criteria } & Fully & Partly met & \multicolumn{2}{l|}{ Not met } & \multicolumn{2}{l|}{ Unknown } \\
\cline { 2 - 9 } & $\mathbf{n}$ & $\mathbf{\%}$ & $\mathbf{n}$ & $\mathbf{\%}$ & $\mathbf{n}$ & $\%$ & $\mathbf{n}$ & $\mathbf{\%}$ \\
\hline $\begin{array}{l}\text { 1. Providing advance documents according to } \\
\text { contract terms }\end{array}$ & 85 & $63 \%$ & 49 & $37 \%$ & 0 & 0 & 0 & 0 \\
\hline 2. Financial viability & 76 & $57 \%$ & 0 & 0 & 5 & $3 \%$ & 53 & $40 \%$ \\
\hline 3. Qualification to tender or procurement & 25 & $19 \%$ & 109 & $81 \%$ & 0 & 0 & 0 & 0 \\
\hline $\begin{array}{l}\text { 4. Providing proof documents about product } \\
\text { quality }\end{array}$ & 81 & $61 \%$ & 48 & $36 \%$ & 0 & 0 & 5 & $3 \%$ \\
\hline 5. Products passing quality tests upon arrival & 22 & $16 \%$ & 104 & $78 \%$ & 8 & $6 \%$ & 0 & 0 \\
\hline $\begin{array}{l}\text { 6. Insurance and shipment according to contract } \\
\text { financial terms }\end{array}$ & 121 & $90 \%$ & 0 & 0 & 0 & 0 & 13 & $10 \%$ \\
\hline $\begin{array}{l}\text { 7. Invoice compliance with contract pricing } \\
\text { terms }\end{array}$ & 117 & $87 \%$ & 0 & 0 & 0 & 0 & 17 & $13 \%$ \\
\hline $\begin{array}{l}\text { 8. Meeting delivery time according to the } \\
\text { contract terms }\end{array}$ & 119 & $89 \%$ & 8 & $6 \%$ & 2 & $1 \%$ & 5 & $4 \%$ \\
\hline 9. Shipping correct products & 130 & $97 \%$ & 0 & 0 & 0 & 0 & 4 & $3 \%$ \\
\hline $\begin{array}{l}\text { 10. Delivering the quantities according to the } \\
\text { contract terms }\end{array}$ & 124 & $93 \%$ & 7 & $5 \%$ & 0 & 0 & 3 & $2 \%$ \\
\hline $\begin{array}{l}\text { 11. Delivering products that comply with } \\
\text { contract terms for remaining shelf life }\end{array}$ & 134 & $100 \%$ & 0 & 0 & 0 & 0 & 0 & 0 \\
\hline 12. Providing correct packaging & 126 & $94 \%$ & 3 & $2 \%$ & 0 & 0 & 5 & $4 \%$ \\
\hline 13. Providing correct labeling & 116 & $87 \%$ & 0 & 0 & 1 & $0.7 \%$ & 17 & $13 \%$ \\
\hline 14. Actively update about order status & 75 & $56 \%$ & 9 & $7 \%$ & 40 & $30 \%$ & 10 & $7 \%$ \\
\hline
\end{tabular}


Figure 5:- Criteria meeting status regardless of requests in the contract terms

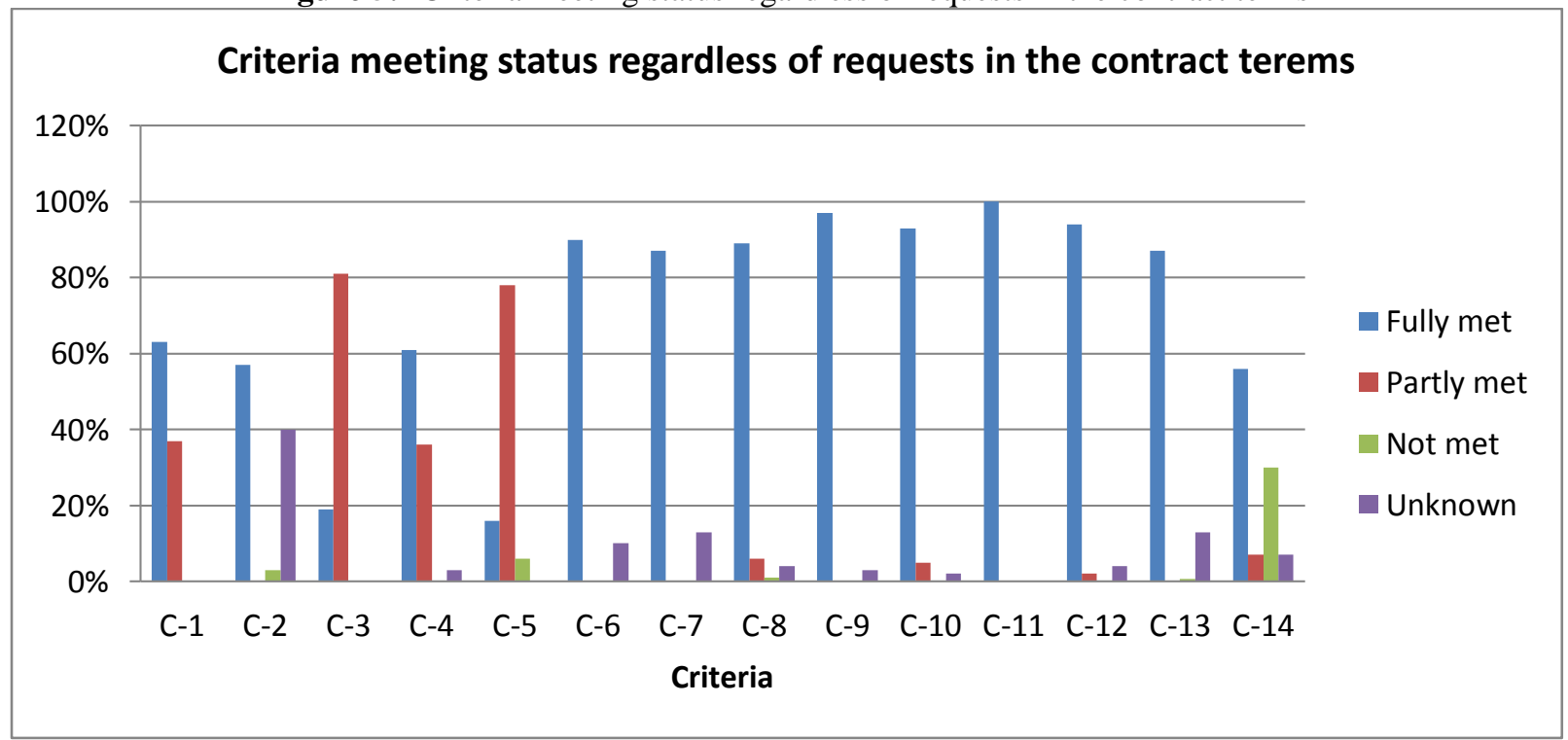

According to the results in Table 12, the scores of the criteria met by the suppliers are presented in Figure 6 . The average score is $80 \%$, and nine $(64 \%)$ of the criteria scored above $80 \%$. When compared to Figure 4 , criteria 6-13 (which are related to delivery services) continue to have a high level of satisfaction; in particular criteria 11, 9, 10 and 12. Criteria 3 (qualification to tender) and 5 (product quality) remain low. The performance on criteria 2 (financial viability) and 14 (active communication) dropped significantly.

Figure 6:- Suppliers' overall scores for each criterion regardless of the requests in the contract terms

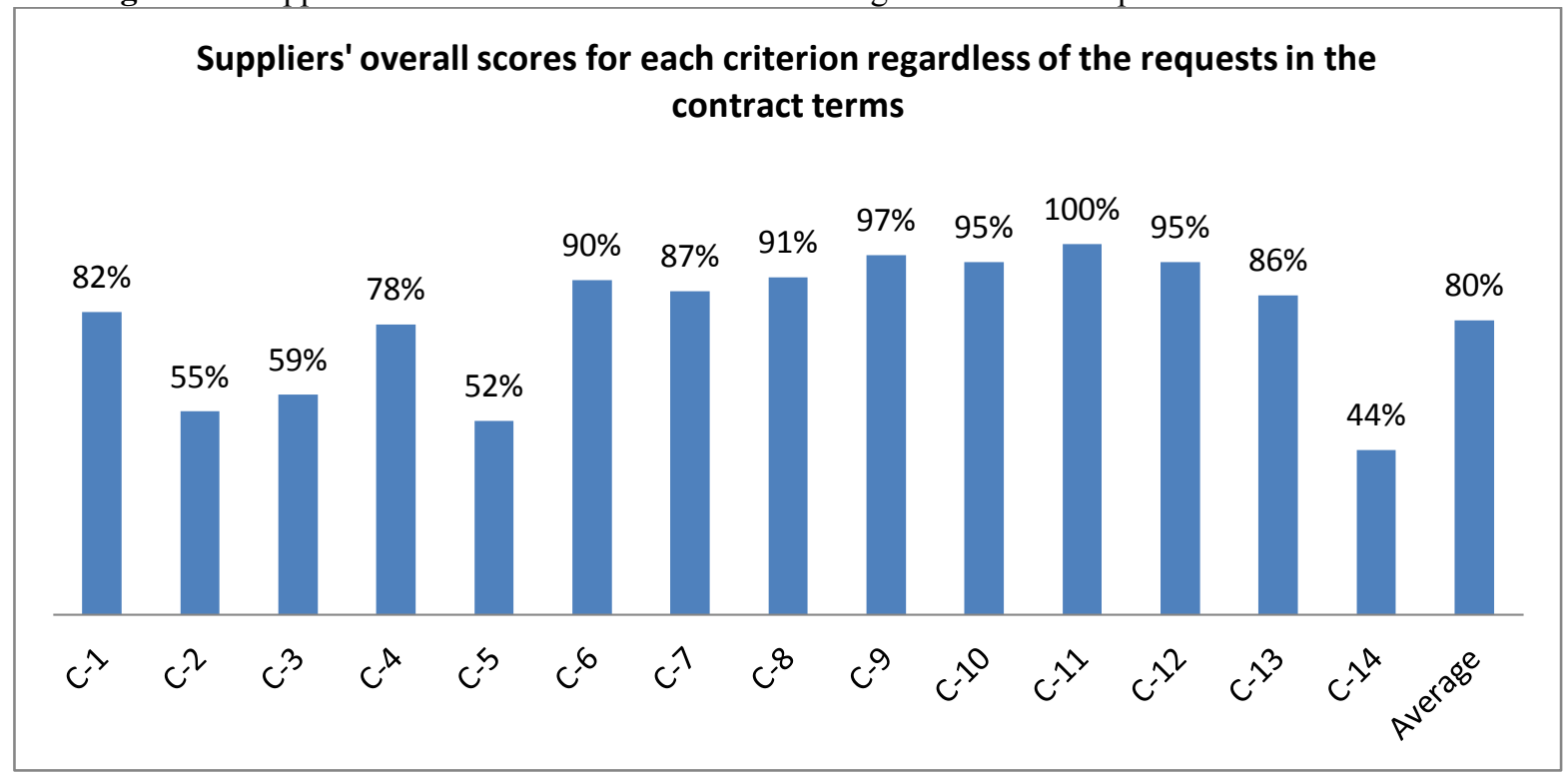

Four criteria (criteria 1, 3, 4, and 5) have sub-criteria. This section presents the results of how the suppliers responded to the requests of organizations for the sub-criteria. Table 13 presents the results about how well suppliers met requests for submitting advanced documents by verifying the proof documents (criterion 1). All organizations requested the suppliers' licenses, as it is the top concern of the organizations about their suppliers. All suppliers were licensed either in Afghanistan or in their countries of origin and met the organizations' requirement. Bank security was the least requested, and was $90 \%$ met. 
Table 13:- Summary of meeting the request of sub-criteria for criterion $1(\mathrm{~N}=134)$

\begin{tabular}{|c|c|c|c|c|c|}
\hline $\begin{array}{c}\text { Sub-criteria for } \\
\text { criterion 1 }\end{array}$ & $\begin{array}{c}\text { Bank } \\
\text { security }\end{array}$ & $\begin{array}{c}\text { Certificate of } \\
\text { analysis }\end{array}$ & CoPP & $\begin{array}{c}\text { GMP } \\
\text { certificate }\end{array}$ & License \\
\hline $\begin{array}{c}\text { Documents available for } \\
\text { verification / requested }\end{array}$ & $47 / 52(90 \%)$ & $114 / 114(100 \%)$ & $106 / 114$ & $104 / 111$ & $134 / 134$ \\
$(93 \%)$ & $(94 \%)$ & $(100 \%)$ \\
\hline
\end{tabular}

Table 14 shows that the four sub-criteria for criterion 3 were requested by all or some of the organizations, and suppliers responded to all requests. However, as Table 11 indicates, criterion 3 was $19 \%$ fully-met and $81 \%$ partly met. As the questionnaire was structured, there was no information collected to explain why it was not all fully met. A side discussion with one of the organizations revealed that some suppliers cannot provide good manufacturing practices (GMP) certificates for all items; thus they consider it partly met in such a circumstance.

Table 14:- Summary of meeting the request of sub-criteria for criterion $3(\mathrm{~N}=134)$.

\begin{tabular}{|c|c|c|c|c|}
\hline $\begin{array}{c}\text { Sub-criteria for } \\
\text { criterion 3 }\end{array}$ & $\begin{array}{c}\text { License, } \\
\text { Afghanistan }\end{array}$ & $\begin{array}{c}\text { License, country } \\
\text { of origin }\end{array}$ & GMP certificate & $\begin{array}{c}\text { WHO } \\
\text { prequalification }\end{array}$ \\
\hline $\begin{array}{c}\text { Documents available for } \\
\text { verification / requested }\end{array}$ & $130 / 130(100 \%)$ & $4 / 4(100 \%)$ & $110 / 110(100 \%)$ & $1 / 1(100 \%)$ \\
\hline
\end{tabular}

Table 15 shows that two sub-criteria - batch certificate and certificate of pharmaceutical product (CoPP)—were requested by some of the organizations, and all their suppliers responded with either one or both of them. However, as Table 11 indicates, criterion 4 was $61 \%$ fully-met and $36 \%$ partly met. In discussion, one of the organizations shared that, though the suppliers responded to the request, not all of them would be able to provide product certificates for all the products.

Table 15:- Summary of meeting the request of sub-criteria for criterion $4(\mathrm{~N}=134)$

\begin{tabular}{|c|c|c|}
\hline $\begin{array}{l}\text { Sub-criteria } \\
\text { criterion } 4\end{array}$ & Batch certificate & CoPP \\
\hline Documents available for verification / requested & $86 / 86(100 \%)$ & $122 / 122(100 \%)$ \\
\hline
\end{tabular}

Table 16 shows that two sub-criteria - exemption letter for quality test and quality certificates — were requested by some of the organizations, and all suppliers responded with either one or both of them. However, as Table 11 indicates, criterion 5 was $17 \%$ fully-met and $83 \%$ partly met. In discussion, one of the organizations shared that not all products were provided with quality certificates.

Table 16:- Summary of meeting the request of sub-criteria for criterion $5(\mathrm{~N}=134)$.

\begin{tabular}{|c|c|c|}
\hline $\begin{array}{c}\text { Sub-criteria for } \\
\text { criterion 5 }\end{array}$ & $\begin{array}{c}\text { MoPH exemption letter for } \\
\text { quality test }\end{array}$ & $\begin{array}{c}\text { Quality certificates issued by MoPH } \\
\text { QC lab }\end{array}$ \\
\hline $\begin{array}{c}\text { Documents available for } \\
\text { verification / requested }\end{array}$ & $24 / 24(100 \%)$ & $124 / 124(100 \%)$ \\
\hline
\end{tabular}

\section{Suppliers' Performance Scores Based on the Requests in the Contract Terms:-}

The suppliers were given scores according to the results in Table 11 and the scoring method described in the Methodology section. The denominators are the number of requests for each criterion; therefore each supplier has its own denominator. Table 16 presents the results of the suppliers based on their responses to the requests in the contract terms. The maximum score $(\mathrm{N})$ represents the full score for all the requested criteria if all are fully met $(\mathrm{N}=$ requested criteria*2). The net score (n) represents the supplier's score of their responses $(2$ for fully met, 1 for partly met, -1 for not met). The results ranged between $97 \%$ (S-22) and $82 \%$ (S-50), and the average score was $90 \%$. Of the 61 suppliers, $34(56 \%)$ have reached the average score or above. According to the rating standard, these 34 suppliers were rated "excellent (5)"; the rest (27, 44\%) were rated "above average (4)." Figure 7 provides a graphic view of these results. 
Table 17:- Suppliers performance scores based on their responses to the requests of the contract terms.

\begin{tabular}{|c|c|c|c|c|c|c|c|c|}
\hline \multirow[t]{2}{*}{$\begin{array}{l}\text { Suppliers' serial } \\
\text { numbers }\end{array}$} & \multicolumn{3}{|c|}{$\begin{array}{l}\text { Criteria meeting } \\
\text { status (contract)* }\end{array}$} & \multirow{2}{*}{$\begin{array}{c}\begin{array}{c}\text { Net } \\
\text { score*** }^{* *}\end{array} \\
\mathbf{n}\end{array}$} & \multirow{2}{*}{$\begin{array}{c}\begin{array}{c}\text { Max } \\
\text { score*** }^{* *}\end{array} \\
\mathbf{N}\end{array}$} & \multirow{2}{*}{$\begin{array}{c}\text { Suppliers' } \\
\text { performance score } \\
\% \text { of } \max (\mathbf{n} / \mathbf{N}) \\
\end{array}$} & \multicolumn{2}{|c|}{ Rating*** } \\
\hline & FM & PM & NM & & & & 5 & 4 \\
\hline S-01 & 31 & 9 & 0 & 71 & 80 & $89 \%$ & & 4 \\
\hline S-02 & 12 & 2 & 0 & 26 & 28 & $93 \%$ & 5 & \\
\hline S-03 & 22 & 5 & 0 & 49 & 54 & $91 \%$ & 5 & \\
\hline S-04 & 22 & 4 & 1 & 47 & 54 & $87 \%$ & & 4 \\
\hline S-05 & 10 & 1 & 0 & 21 & 22 & $95 \%$ & 5 & \\
\hline S-06 & 38 & 5 & 0 & 81 & 86 & $94 \%$ & 5 & \\
\hline S-07 & 12 & 2 & 0 & 26 & 28 & $93 \%$ & 5 & \\
\hline S-08 & 22 & 5 & 0 & 49 & 54 & $91 \%$ & 5 & \\
\hline S-09 & 40 & 7 & 0 & 87 & 94 & $93 \%$ & 5 & \\
\hline S-10 & 30 & 7 & 0 & 67 & 74 & $91 \%$ & 5 & \\
\hline S-11 & 19 & 6 & 0 & 44 & 50 & $88 \%$ & & 4 \\
\hline S-12 & 10 & 3 & 0 & 23 & 26 & $88 \%$ & & 4 \\
\hline S-13 & 7 & 2 & 0 & 16 & 18 & $89 \%$ & & 4 \\
\hline S-14 & 10 & 2 & 0 & 22 & 24 & $92 \%$ & 5 & \\
\hline S-15 & 28 & 6 & 0 & 62 & 68 & $91 \%$ & 5 & \\
\hline S-16 & 13 & 1 & 0 & 27 & 28 & $96 \%$ & 5 & \\
\hline S-17 & 10 & 1 & 0 & 21 & 22 & $95 \%$ & 5 & \\
\hline S-18 & 12 & 2 & 0 & 26 & 28 & $93 \%$ & 5 & \\
\hline S-19 & 18 & 8 & 0 & 44 & 52 & $85 \%$ & & 4 \\
\hline S-20 & 10 & 3 & 0 & 23 & 26 & $88 \%$ & & 4 \\
\hline S-21 & 18 & 5 & 0 & 41 & 46 & $89 \%$ & & 4 \\
\hline S-22 & 18 & 1 & 0 & 37 & 38 & $97 \%$ & 5 & \\
\hline S-23 & 30 & 8 & 0 & 68 & 76 & $89 \%$ & & 4 \\
\hline S-24 & 19 & 8 & 0 & 46 & 54 & $85 \%$ & & 4 \\
\hline S-25 & 75 & 21 & 1 & 170 & 194 & $88 \%$ & & 4 \\
\hline S-26 & 8 & 4 & 0 & 20 & 24 & $83 \%$ & & 4 \\
\hline S-27 & 12 & 2 & 0 & 26 & 28 & $93 \%$ & 5 & \\
\hline S-28 & 22 & 5 & 0 & 49 & 54 & $91 \%$ & 5 & \\
\hline S-29 & 10 & 3 & 0 & 23 & 26 & $88 \%$ & & 4 \\
\hline S-30 & 10 & 3 & 0 & 23 & 26 & $88 \%$ & & 4 \\
\hline S-31 & 8 & 2 & 0 & 18 & 20 & $90 \%$ & 5 & \\
\hline S-32 & 12 & 1 & 0 & 25 & 26 & $96 \%$ & 5 & \\
\hline S-33 & 9 & 3 & 0 & 21 & 24 & $88 \%$ & & 4 \\
\hline S-34 & 9 & 4 & 0 & 22 & 26 & $85 \%$ & & 4 \\
\hline S-35 & 24 & 3 & 0 & 51 & 54 & $94 \%$ & 5 & \\
\hline S-36 & 31 & 9 & 0 & 71 & 80 & $89 \%$ & & 4 \\
\hline S-37 & 10 & 3 & 0 & 23 & 26 & $88 \%$ & & 4 \\
\hline S-38 & 22 & 5 & 0 & 49 & 54 & $91 \%$ & 5 & \\
\hline S-39 & 15 & 3 & 0 & 33 & 36 & $92 \%$ & 5 & \\
\hline S-40 & 53 & 12 & 1 & 117 & 132 & $89 \%$ & & 4 \\
\hline S-41 & 26 & 2 & 0 & 54 & 56 & $96 \%$ & 5 & \\
\hline S-42 & 13 & 5 & 0 & 31 & 36 & $86 \%$ & & 4 \\
\hline S-43 & 10 & 2 & 0 & 22 & 24 & $92 \%$ & 5 & \\
\hline S-44 & 12 & 2 & 0 & 26 & 28 & $93 \%$ & 5 & \\
\hline S-45 & 15 & 6 & 0 & 36 & 42 & $86 \%$ & & 4 \\
\hline S-46 & 10 & 3 & 0 & 23 & 26 & $88 \%$ & & 4 \\
\hline S-47 & 22 & 5 & 0 & 49 & 54 & $91 \%$ & 5 & \\
\hline S-48 & 22 & 5 & 0 & 49 & 54 & $91 \%$ & 5 & \\
\hline S-49 & 22 & 5 & 0 & 49 & 54 & $91 \%$ & 5 & \\
\hline $\mathrm{S}-50$ & 27 & 11 & 1 & 64 & 78 & $82 \%$ & & 4 \\
\hline
\end{tabular}




\begin{tabular}{|c|c|c|c|c|c|c|c|c|}
\hline S-51 & 41 & 7 & 0 & 89 & 96 & $93 \%$ & 5 & \\
\hline S-52 & 10 & 2 & 0 & 22 & 24 & $92 \%$ & 5 & \\
\hline S-53 & 63 & 12 & 0 & 138 & 150 & $92 \%$ & 5 & \\
\hline S-54 & 16 & 8 & 0 & 40 & 48 & $83 \%$ & & 4 \\
\hline S-55 & 10 & 3 & 0 & 23 & 26 & $88 \%$ & & 4 \\
\hline S-56 & 10 & 3 & 0 & 23 & 26 & $88 \%$ & & 4 \\
\hline S-57 & 12 & 2 & 0 & 26 & 28 & $93 \%$ & 5 & \\
\hline S-58 & 85 & 27 & 1 & 196 & 226 & $87 \%$ & & 4 \\
\hline S-59 & 10 & 1 & 0 & 21 & 22 & $95 \%$ & 5 & \\
\hline S-60 & 22 & 5 & 0 & 49 & 54 & $91 \%$ & 5 & \\
\hline S-61 & 101 & 19 & 0 & 221 & 240 & $92 \%$ & 5 & $\mathbf{2 7}$ \\
\hline $\begin{array}{c}\text { Total/ } \\
\text { average \%: }\end{array}$ & $\mathbf{1 , 3 5 0}$ & $\mathbf{3 2 1}$ & $\mathbf{5}$ & $\mathbf{3 , 0 1 6}$ & $\mathbf{3 , 3 5 2}$ & $\mathbf{9 0 \%}$ (average) & $\mathbf{3 4}$ & $\mathbf{2 7}$ \\
\hline
\end{tabular}

*Criteria meeting status: FM-fully met; PM-partly met; NM-not met

**Net score (responses): $\mathrm{n}=\left(\mathrm{FM}^{*} 2\right)+\left(\mathrm{PM}^{*} 1\right)+(\mathrm{NM} *-1)$; Max score (requests): $\mathrm{N}=(\mathrm{FM}+\mathrm{PM}+\mathrm{NM}) * 2$

***Rating: 5=Excellent $(90 \%-100 \%) ; 4=$ Above average $(80 \%-89 \%)$

Figure 7;- Suppliers' performance scores based on their responses to requests in contract terms.

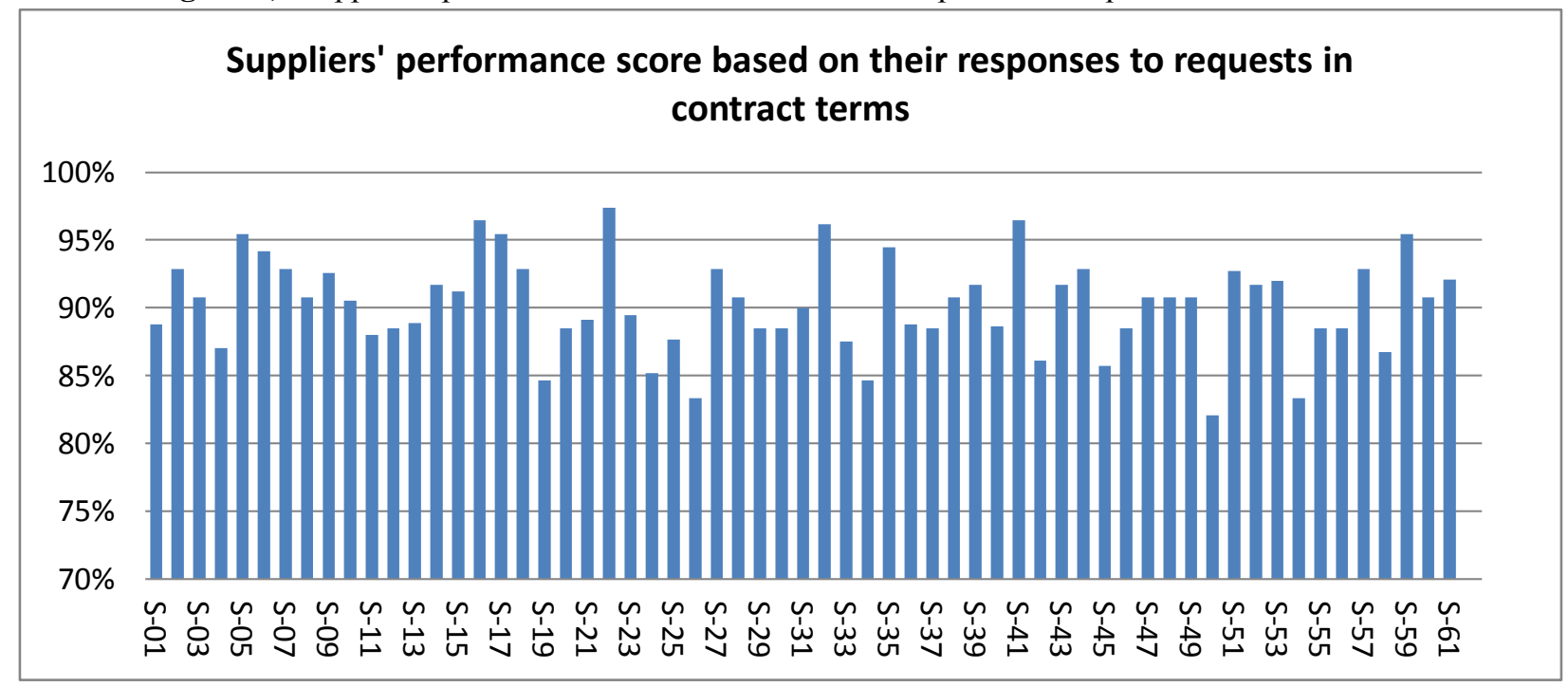

\section{Suppliers' Overall Performance Scores:-}

The suppliers' performance was also measured regardless of whether the criteria were requested in the purchase order or in a contract. They were given scores according to the results in Table 12 and the scoring method described in the Methodology section. The scoring results are presented in Table 18 and Figure 8 . The average score was $80 \%$; $35(57 \%)$ suppliers were beyond average score. Eight (13\%) suppliers were rated 5 (excellent), two suppliers (S-16 and S-41) had the highest score of $96 \%$. Twenty-seven (44\%) suppliers were rated 4 (above average), followed by $23(38 \%)$ of which were rated 3 (average). Three suppliers (S-39, S-13, and S-43) were rated below average and require more efforts for improvements. 
Table 18:- Suppliers' performance scores regardless the requests in the contract terms.

\begin{tabular}{|c|c|c|c|c|c|c|c|c|c|c|c|c|}
\hline \multirow{2}{*}{$\begin{array}{l}\text { Supplier } \\
\text { s' serial } \\
\text { numbers }\end{array}$} & \multicolumn{4}{|c|}{$\begin{array}{l}\text { Overall criteria } \\
\text { meeting Status* }\end{array}$} & \multirow{2}{*}{$\begin{array}{c}\begin{array}{c}\text { Net } \\
\text { score** }\end{array} \\
\mathbf{n}\end{array}$} & \multirow{2}{*}{$\begin{array}{c}\begin{array}{c}\text { Max } \\
\text { score }\end{array} \\
\mathbf{N}\end{array}$} & \multirow{2}{*}{$\begin{array}{c}\text { Suppliers' } \\
\text { performance score } \\
\% \text { of } \operatorname{Max}(\mathbf{n} / \mathbf{N})\end{array}$} & \multicolumn{5}{|c|}{ Rating**** } \\
\hline & FM & $\begin{array}{l}\mathbf{P} \\
\mathbf{M}\end{array}$ & $\begin{array}{l}\mathbf{N} \\
\mathbf{M}\end{array}$ & $\begin{array}{l}\mathbf{U} \\
\mathbf{K}\end{array}$ & & & & 5 & 4 & 3 & 2 & 1 \\
\hline S-01 & 31 & 9 & 0 & 2 & 71 & 84 & $85 \%$ & & 4 & & & \\
\hline S-02 & 12 & 2 & 0 & 0 & 26 & 28 & $93 \%$ & 5 & & & & \\
\hline S-03 & 22 & 5 & 0 & 1 & 49 & 56 & $88 \%$ & & 4 & & & \\
\hline S-04 & 22 & 4 & 2 & 0 & 46 & 56 & $82 \%$ & & 4 & & & \\
\hline S-05 & 10 & 1 & 2 & 1 & 19 & 28 & $68 \%$ & & & 3 & & \\
\hline S-06 & 38 & 5 & 4 & 9 & 77 & 112 & $69 \%$ & & & 3 & & \\
\hline S-07 & 12 & 2 & 0 & 0 & 26 & 28 & $93 \%$ & 5 & & & & \\
\hline S-08 & 22 & 5 & 0 & 1 & 49 & 56 & $88 \%$ & & 4 & & & \\
\hline $\begin{array}{l}\text { S-09 } \\
\end{array}$ & 40 & 8 & 0 & 8 & 88 & 112 & $79 \%$ & & & 3 & & \\
\hline S-10 & 30 & 8 & 0 & 4 & 68 & 84 & $81 \%$ & & 4 & & & \\
\hline S-11 & 19 & 6 & 1 & 2 & 43 & 56 & $77 \%$ & & & 3 & & \\
\hline S-12 & 10 & 3 & 0 & 1 & 23 & 28 & $82 \%$ & & 4 & & & \\
\hline S-13 & 7 & 2 & 1 & 4 & 15 & 28 & $54 \%$ & & & & 2 & \\
\hline S-14 & 10 & 2 & 1 & 1 & 21 & 28 & $75 \%$ & & & 3 & & \\
\hline S-15 & 28 & 6 & 1 & 7 & 61 & 84 & $73 \%$ & & & 3 & & \\
\hline S-16 & 13 & 1 & 0 & 0 & 27 & 28 & $96 \%$ & 5 & & & & \\
\hline S-17 & 10 & 2 & 1 & 1 & 21 & 28 & $75 \%$ & & & 3 & & \\
\hline S-18 & 12 & 2 & 0 & 0 & 26 & 28 & $93 \%$ & 5 & & & & \\
\hline S-19 & 18 & 8 & 0 & 2 & 44 & 56 & $79 \%$ & & & 3 & & \\
\hline S-20 & 10 & 3 & 0 & 1 & 23 & 28 & $82 \%$ & & 4 & & & \\
\hline S-21 & 18 & 6 & 1 & 3 & 41 & 56 & $73 \%$ & & & 3 & & \\
\hline S-22 & 18 & 1 & 2 & 7 & 35 & 56 & $63 \%$ & & & 3 & & \\
\hline $\mathrm{S}-23$ & 30 & 8 & 1 & 3 & 67 & 84 & $80 \%$ & & 4 & & & \\
\hline S-24 & 19 & 8 & 0 & 1 & 46 & 56 & $82 \%$ & & 4 & & & \\
\hline S-25 & 75 & 23 & 7 & 7 & 166 & 224 & $74 \%$ & & & 3 & & \\
\hline S-26 & 8 & 4 & 0 & 2 & 20 & 28 & $71 \%$ & & & 3 & & \\
\hline S-27 & 12 & 2 & 0 & $\overline{0}$ & 26 & 28 & $93 \%$ & 5 & & & & \\
\hline S-28 & 22 & 5 & 0 & 1 & 49 & 56 & $88 \%$ & & 4 & & & \\
\hline S-29 & 10 & 3 & 0 & 1 & 23 & 28 & $82 \%$ & & 4 & & & \\
\hline S-30 & 10 & 3 & 0 & 1 & 23 & 28 & $82 \%$ & & 4 & & & \\
\hline S-31 & 8 & 3 & 0 & 3 & 19 & 28 & $68 \%$ & & & 3 & & \\
\hline S-32 & 12 & 1 & 0 & 1 & 25 & 28 & $89 \%$ & & 4 & & & \\
\hline S-33 & 9 & 3 & 1 & 1 & 20 & 28 & $71 \%$ & & & 3 & & \\
\hline $\begin{array}{l}\mathrm{S}-34 \\
\end{array}$ & 9 & 4 & 0 & 1 & 22 & 28 & $79 \%$ & & & 3 & & \\
\hline $\mathrm{S}-35$ & 24 & 3 & 1 & 0 & 50 & 56 & $89 \%$ & & 4 & & & \\
\hline S-36 & 31 & 9 & 0 & 2 & 71 & 84 & $85 \%$ & & 4 & & & \\
\hline S-37 & 10 & 3 & 0 & 1 & 23 & 28 & $82 \%$ & & 4 & & & \\
\hline S-38 & 22 & 5 & 1 & 0 & 48 & 56 & $86 \%$ & & 4 & & & \\
\hline S-39 & 15 & 4 & 2 & 7 & 32 & 56 & $57 \%$ & & & & 2 & \\
\hline $\mathrm{S}-40$ & 53 & 12 & 3 & 2 & 115 & 140 & $82 \%$ & & 4 & & & \\
\hline S-41 & 26 & 2 & 0 & 0 & 54 & 56 & $96 \%$ & 5 & & & & \\
\hline S-42 & 17 & 7 & 0 & 4 & 41 & 56 & $73 \%$ & & & 3 & & \\
\hline S-43 & 6 & 0 & 1 & 7 & 11 & 28 & $39 \%$ & & & & & 1 \\
\hline S-44 & 12 & 2 & 0 & 0 & 26 & 28 & $93 \%$ & 5 & & & & \\
\hline S-45 & 15 & 7 & 2 & 4 & 35 & 56 & $63 \%$ & & & 3 & & \\
\hline S-46 & 10 & 3 & 0 & 1 & 23 & 28 & $82 \%$ & & 4 & & & \\
\hline S-47 & 22 & 5 & 1 & 0 & 48 & 56 & $86 \%$ & & 4 & & & \\
\hline S-48 & 22 & 5 & 1 & 0 & 48 & 56 & $86 \%$ & & 4 & & & \\
\hline S-49 & 22 & 5 & 1 & 0 & 48 & 56 & $86 \%$ & & 4 & & & \\
\hline
\end{tabular}




\begin{tabular}{|c|c|c|c|c|c|c|c|c|c|c|c|c|}
\hline S-50 & 27 & 11 & 2 & 2 & 63 & 84 & $75 \%$ & & & 3 & & \\
\hline S-51 & 41 & 9 & 4 & 2 & 87 & 112 & $78 \%$ & & & 3 & & \\
\hline S-52 & 10 & 2 & 1 & 1 & 21 & 28 & $75 \%$ & & & 3 & & \\
\hline S-53 & 63 & 15 & 4 & 2 & 137 & 168 & $82 \%$ & & 4 & & & \\
\hline S-54 & 16 & 8 & 0 & 4 & 40 & 56 & $71 \%$ & & & 3 & & \\
\hline S-55 & 10 & 3 & 0 & 1 & 23 & 28 & $82 \%$ & & 4 & & & \\
\hline S-56 & 10 & 3 & 0 & 1 & 23 & 28 & $82 \%$ & & 4 & & & \\
\hline S-57 & 12 & 2 & 0 & 0 & 26 & 28 & $93 \%$ & 5 & & & & \\
\hline S-58 & 86 & 28 & 5 & 7 & 195 & 252 & $77 \%$ & & & 3 & & \\
\hline $\begin{array}{l}S-59 \\
\end{array}$ & 10 & 2 & 0 & 2 & 22 & 28 & $79 \%$ & & & 3 & & \\
\hline S-60 & 22 & 5 & 1 & 0 & 48 & 56 & $86 \%$ & & 4 & & & \\
\hline S-61 & 101 & 19 & 1 & 5 & 220 & 252 & $87 \%$ & & 4 & & & \\
\hline $\begin{array}{c}\text { Total/ } \\
\text { average } \\
\%:\end{array}$ & $\begin{array}{c}1,35 \\
1\end{array}$ & $\begin{array}{c}33 \\
7\end{array}$ & 56 & $\begin{array}{c}13 \\
2\end{array}$ & 2,983 & 3,752 & $80 \%$ (average) & $\begin{array}{l}8 \\
( \\
1 \\
3 \\
\% \\
)\end{array}$ & $\begin{array}{l}27 \\
(44 \\
\%)\end{array}$ & $\begin{array}{c}23 \\
(3 \\
8 \\
\% \\
)\end{array}$ & $\begin{array}{l}2 \\
( \\
3 \\
\% \\
)\end{array}$ & $\begin{array}{c}1 \\
(1 \% \\
)\end{array}$ \\
\hline
\end{tabular}

*Criteria meeting status: $\mathrm{FM}=$ fully met; $\mathrm{PM}=$ partly met; $\mathrm{NM}=$ not met; $\mathrm{UK}=$ unknown

**Net score: $\mathrm{n}=(\mathrm{FM} * 2)+(\mathrm{PM} * 1)+\left(\mathrm{NM}^{*}-1\right)$; Max score: $\mathrm{N}=(\mathrm{FM}+\mathrm{PM}+\mathrm{NM}) * 2$

***Rating: 5=Excellent (90\%-100\%); 4=Above average $(80 \%-89 \%) ; 3=$ Average $(60 \%-79 \%) ; 2=$ Need Improvements (40\%-59\%); 1=Unacceptable (0\%-39\%)

Figure 8:- Suppliers' performance scores, regardless of the requests in contract terms

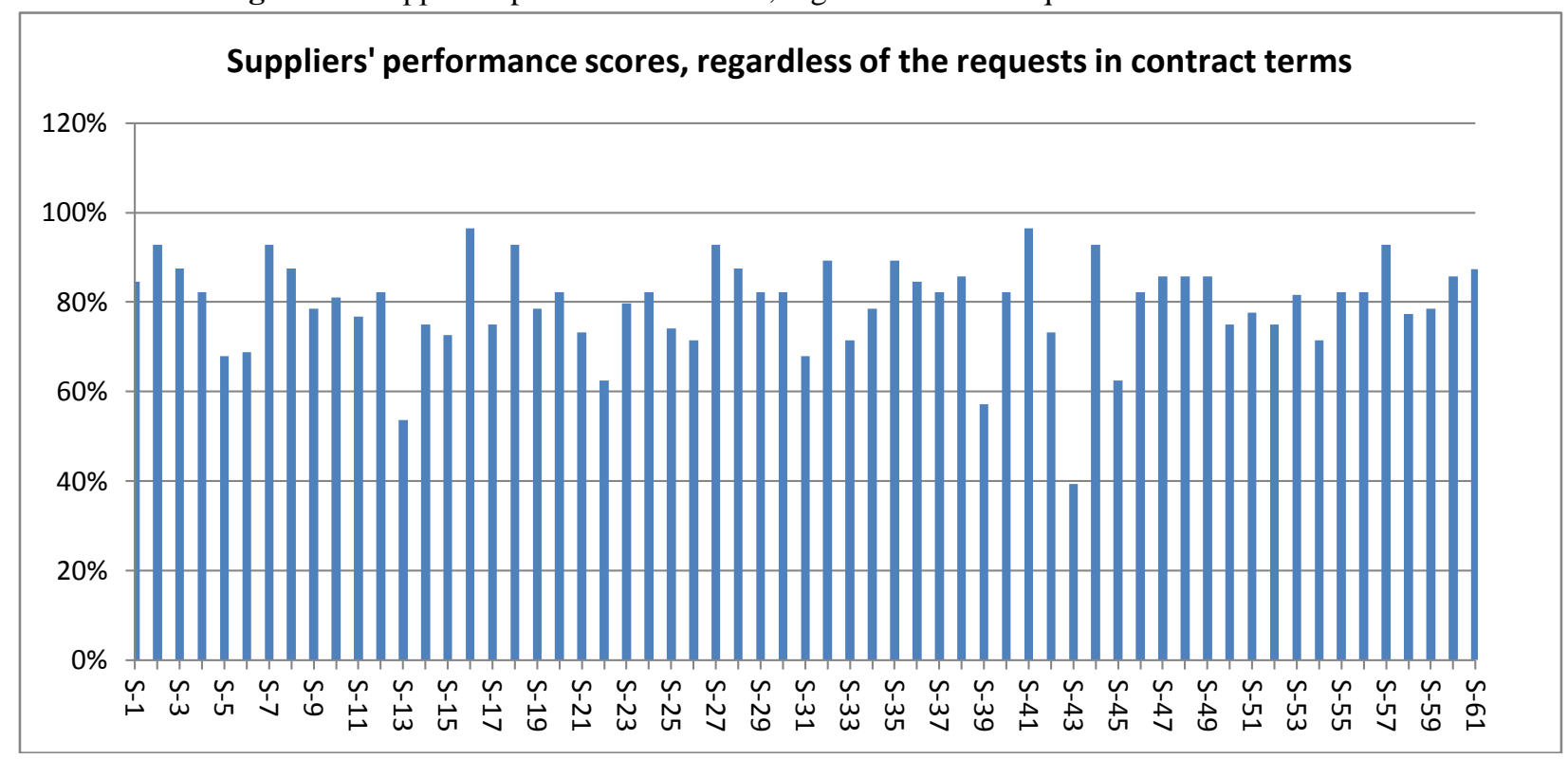

The comparison of the ratings between requests and regardless of requests in the contract terms is presented in Figure 9. It shows that most suppliers were able to satisfy the customers by responding to the requests in the contract terms. 
Figure 9:- Comparison of the ratings between requests and regardless of requests in the contract terms.

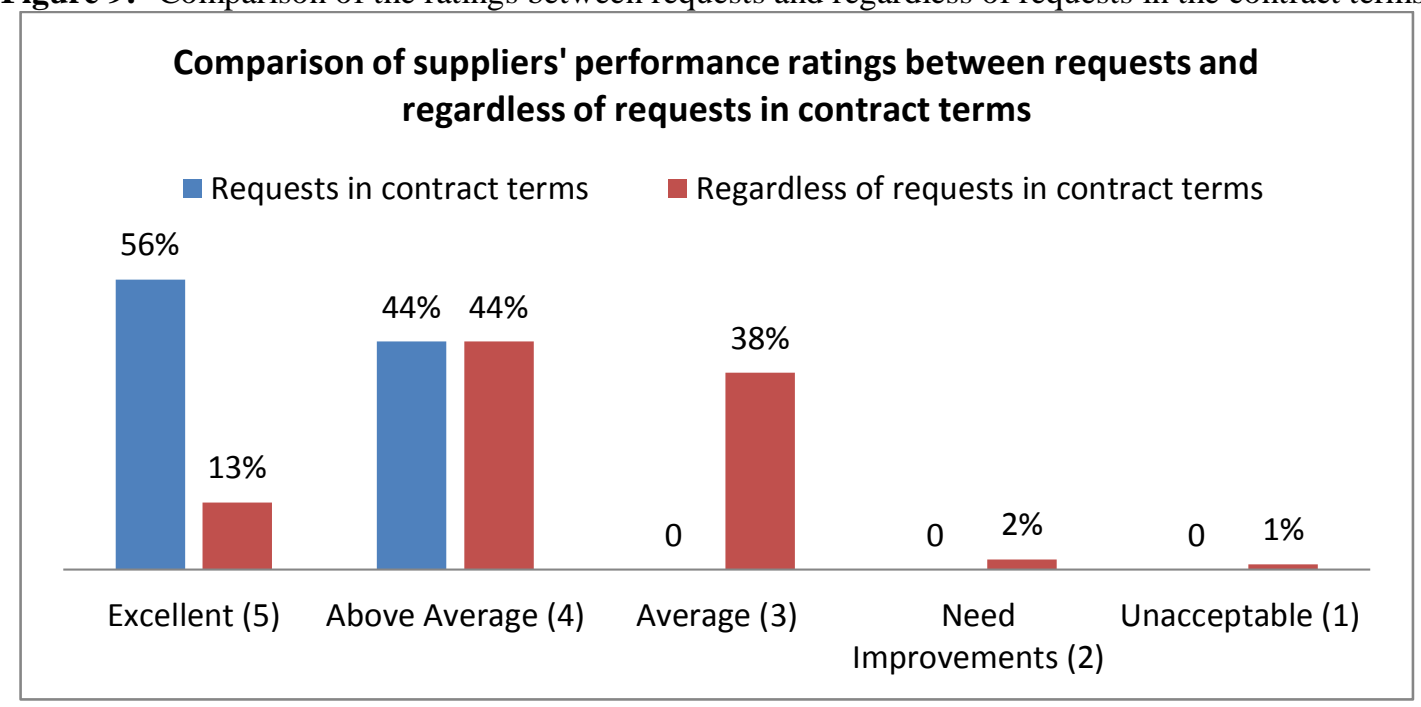

The details of Table 18 and Figure 8 are shown in Annex 3 and Annex 4.

\section{Result and Discussion:-}

This survey identified the respondent organizations' operations in monitoring suppliers' performance, and how the suppliers performed recently according to the respondents' feedback for the selected criteria. The key findings are summarized as follows-

\section{Respondent organizations' operations:-}

- All 29 organizations (100\%) purchased pharmaceuticals from the local market; in particular, from importers. Of them, four (14\%) also purchased directly from the international market.

- Twenty organizations (69\%) monitored the performance of their suppliers.

- Eight $(40 \%)$ of those organizations monitoring the performance of their suppliers did so at regular monitoring intervals.

- The majority of organizations documented the results of this monitoring in reports (50\%) or checklists (40\%).

- Thirteen organizations (45\%) had only one supplier in their most recent regular procurement prior to the survey; $16(55 \%)$ had between three and 25 suppliers.

- The criterion of Suppliers' licenses (a sub-criterion in criteria 1 and 3) was applied by all organizations, either locally or (foreign) country of origin. The criteria applied by at least $90 \%$ of the organizations were: Shipping correct products (criterion 9), Remaining shelf lives of the received products (criterion 11), Product quality certificates (a sub-criterion in criteria 1 and 5), Compliance in mode and costs of insurance and shipment (criterion 6), and all the criteria regarding delivery (criteria 8-13).

\section{Suppliers' information and performance:-}

- All 61 suppliers were registered in their countries of origin: 57 (93\%) were registered in Afghanistan and four (7\%) international suppliers were registered in other countries: one in Ireland, one in Netherlands, and two in India.

- Fifty-five (90\%) of the 61 suppliers are local importers.

- Of the 61 suppliers, 27 (44\%) only served one organization, and 20 (33\%) only served two organizations in the purchases prior to this survey.

- The suppliers' performance on the requests in the contract terms showed $90 \%$ receiving an average score. According to the Likert scale rating, $56 \%$ of the suppliers were rated "excellent ( $90 \%$ and above)"; the rest were rated "above average (80-89\%)."

- The suppliers responded to the requests on the contract terms for criteria 6-14 (delivery services and shelf life) and criterion 2 (financial viability) with scores of $90 \%$ or above, which is far better than the performance for criteria 3 and 5 (qualification for tender and product quality), which only scored 59\%. 
- Suppliers' performance, regardless of whether there were requests in the contract terms, showed good satisfaction in criteria $11,9,10,12$, and 6 (shelf life and delivery services); these scored at least $90 \%$. Criteria 3, 5 , and 14 had scores less than $60 \%$.

- The average suppliers' performance, regardless of the requests in the contract terms, showed $80 \%$ average score. Thirty-five (57\%) suppliers were beyond average score. Eight (13\%) suppliers were rated "5 (excellent)" and two (S-16 and S-41) had the highest score of 96\%. Twenty-seven (44\%) suppliers were rated "4 (above average)," followed by 23 (38\%) of them which were rated "3 (average)." Three suppliers (S-39, S-13, and S43) were rated below average and require more efforts for improvements.

The results showed that more than two-thirds of the organizations monitored suppliers' performance with records, despite that less than half of them did so regularly. One of the organizations stated their monitoring reports were in fact the performance of the procurement process, which included suppliers' performance. This is a good sign regarding procurement management in the organizations. However, further studies may help determine how costeffective their procurement management was, and how it contributes to procuring good-quality pharmaceuticals.

In general procurement management, sourcing products from multiple suppliers is widely preferred in order to promote competition in costs and quality. This survey found that nearly half of the organizations only reported one supplier in their recent regular purchase. Because procurement methods were not included in this survey, it was assumed that organizations might have direct procurement from sole supplier, or that organizations opted to use that single provider after comparing multiple quotations.

This survey identified the criteria that are of most concern to the organizations; these include supplier's license, proof of product quality, shelf life, delivery services, shipment insurance, and costs. GMP and WHO prequalification certificates, and proactive communication were among the least-applied criteria. Compared to the results of supplier performance, it was found the suppliers had better performance in licensing, the remaining shelf life of products, and most of the delivery services than other criteria areas. Organizations had the least satisfaction in suppliers' product-quality certificates, proof of financial viability, and proactive communications. However, the results from the suppliers' responses to the requests in the contract terms show that the suppliers were able to perform better when the criteria were specified as requirements in the contract terms (in particular, with financial viability and active communication, among other criteria related to delivery services). The common weakness is the low performance in criteria 3 and 5, which are mainly about proof of product quality. These results reflect two phenomena: pharmaceutical supply in the public sector performs better in availability than in quality (confirm the widespread concern about quality of medicines in Afghanistan), and suppliers were mostly responsive to requirements specified in contract terms. How the buyers manage the suppliers and the procurement contracts would largely contribute to the performance of both the suppliers and the overall procurement management.

It was noticed that very few of the organizations requested or had information about the financial viability of their suppliers. It is important to reduce risk by selecting financially sound suppliers that are expected to remain in business for the long term (Suárez Bello, 2003).

Using a scoring method according to the criteria meeting status (without weighting criteria), the suppliers were ranked with their overall performance. Those that responded to the requests in the contract terms showed all suppliers were scored $80 \%$ and above. Regardless of requests in contract terms, over half $(57 \%)$ of the suppliers scored above average (80\%). These results seem to be encouraging. Using the Likert scale to rate the suppliers' overall performance is easy and convenient for identifying suppliers' performance levels. The "5-excellent" suppliers will be role models to other suppliers, in particular, to those performing below average. The results would help the procurement agencies improve their own procurement management, select the credible suppliers, and inform suppliers that perform poorly to make improvements.

The survey found that Afghanistan's public health sector heavily relies on imported pharmaceuticals through local importers. Since importers, and local and foreign distributers do not produce pharmaceuticals, information regarding the actual manufacturer(s) of the pharmaceuticals is required (WHO/WPRO, 2002). In this survey, all the suppliers were registered locally or in their countries of origin, thereby fulfilling the most essential requirement. However, not all of them could meet other requirements such as manufacturers' GMP certificates or product certificates. These requirements (criteria 1 and 3) are the key indicators that help organizations select suppliers, and they are key criteria for supplier prequalification (WHO/WPRO, 2002). Additionally, if the supplier is known to the procurement 
agency, evaluation of past performance is part of the prequalification (WHO/WPRO, 2002). The organizations should make sure that the supplier has significant experience in the pharmaceutical industry and is cognizant of the governing regulations (Salama, 2005). Companies that do not appear viable must be avoided (WHO/WPRO, 2002).

Various methodologies in measuring suppliers' performance may lead to different results. The categorical, unweighted method used in this survey gave each criterion the same weight. This enabled identification of suppliers' strengths and weaknesses in each criterion at the same basis. Based on the results, weight points for the criteria can be jointly agreed upon by the participating organizations that monitor and evaluate the suppliers in a harmonized manner. In most cases, in particular for pharmaceuticals, product-quality related criteria have higher weights than other criteria (Abdolshah, 2013) (Enyinda, et al., 2010) (Suárez Bello, 2003). However, some procurement agencies regard price as the top criterion, followed by quality or delivery criteria (Pal, et al., 2013) (Liu, n.d.).

In an organization or a procurement agency, monitoring supplier performance does not end at reporting or presenting the results. The results are used to make decisions about how the organizations (buyers) should manage the procurement and suppliers, what criteria should be tracked more closely, supplier selection or prequalification; to build supplier capacity; and to maintain constructive relationships with suppliers. In this survey, quality-related criteria were deemed imperative by the organizations, but they were not well satisfied by the suppliers. Therefore, measures to ensure that the suppliers meet quality-related criteria should be enforced. This survey provides a preliminary scenario about suppliers that could be selected or prequalified, and what suppliers' capacity should be improved in certain areas. Further communications between the organizations and suppliers to discuss strengths, weaknesses, and interventions to improve both the organization's and the supplier's capacity in managing procurement will be a constructive, "win-win" solution to maintain the buyer-supplier relationship and to improve procurement performance. The organizations should also encourage the suppliers to comply with the regulatory requirements and expectations of the quality of pharmaceuticals and medical devices (PQG, 2010).

\section{Conclusion and Recommendations:-}

In conclusion, monitoring suppliers' performance has been part of the procurement management in most of the organizations in various manners, and suppliers' performance was better in delivery services than in product quality. Therefore, there is potential for building a harmonized mechanism among organizations for monitoring suppliers' performance in their procurement management systems, and prequalification of suppliers in Afghanistan's context. The following recommendations may be helpful for moving forward.

\section{Building the capacity and systems of stakeholder organizations:-}

- The organizations may agree to adopt the common criteria and methods used in this survey for monitoring suppliers, and to modify the scoring/rating method by weighting prioritized criteria (in particular, qualityrelated criteria).

- Specify the criteria in the procurement contract terms or purchase orders. Highlight the requirements of qualityrelated proof for contracting suppliers in the procurement regulations or guidelines. The organizations' procurement managers should enforce the implementation of these regulations or guidelines in the contract terms.

- Within CPDS, the implementers should share information of suppliers' performance using the common criteria, and share their strategies of communicating with suppliers and improving suppliers' performance.

- Wherever possible - or if a national prequalification system of pharmaceutical suppliers is not in place - the organizations may establish a prequalification system for their procurement management system. The CPDS may establish a joint prequalified suppliers' pool that would influence suppliers to improve their product quality and services.

\section{Help MoPH and stakeholder organizations to build supplier capacity and systems:-}

- The MoPH or stakeholder organizations should establish a prequalification system for pharmaceutical suppliers to guide supplier sourcing for pharmaceutical procurement, and to encourage competitions among suppliers in improving product quality and delivery services.

- The MoPH should encourage the local suppliers to pursue international quality standards (such as ISO certification).

- The MoPH/GDPA or stakeholder organizations should try to understand the barriers suppliers face when trying to obtain proof of product quality and other services. 
- The MoPH should seek opportunities to build the capacity of suppliers in order to improve the private sector's performance.

- Stakeholder organizations should recognize successes of the suppliers and enforce contractual consequences and/or penalties when suppliers fail to comply with the terms of their contracts (Harton, 2004)

Annex 1:- List of participating organizations.

\begin{tabular}{|c|c|}
\hline Names of the organizations (by type of organization and alphabetic order) & Type of organization \\
\hline Procurement Directorate (PD) & Government entity \\
\hline Pharmaceutical Enterprise (PE) & Government entity \\
\hline Afghan Health and Development Services (AHDS) & National NGO \\
\hline Bakhtar Development Network (BDN) & National NGO \\
\hline Care of Afghan Families (CAF) & National NGO \\
\hline Humanitarian Assistance Development Association for Afghanistan (HADAAF) & National NGO \\
\hline Move Welfare Organization (MOVE) & National NGO \\
\hline Solidarity for Afghan Families (SAF) & National NGO \\
\hline Aga Khan Health Service - Afghanistan (AKHS) & International NGO \\
\hline Neans-Cultural Psychosocial Organization (HN-TPO) & International NGO \\
\hline International Medical Corps (IMC) & International NGO \\
\hline Medical Refresher Courses for Afghans (MRCA) & International NGO \\
\hline Sremere Urgence - Aide Medical International (PU-AMI) & International NGO \\
\hline Save the Children International (SCI) & International NGO \\
\hline Swedish Committee for Afghanistan (SCA) & International NGO \\
\hline French Medical Institute for Children (FMIC) & Other \\
\hline Antani Hospital & National hospital \\
\hline Barchi 50 Bed Hospital & National hospital \\
\hline Central Poli Clinic & National hospital \\
\hline Disabled Hospital & National hospital \\
\hline Ibn Sina Emergency Hospital & National hospital \\
\hline Indira Ghandi Hospital & National hospital \\
\hline Istiqlal Hospital & National hospital \\
\hline Jamhoryat Hospital & National hospital \\
\hline Mabialai Hospital & National hospital \\
\hline Sadri Ibn Sina Hospital & National hospital \\
\hline Stomatology Hospital & National hospital \\
\hline Wazir Akbar Khan Hospital (WAKH) & National hospital \\
\hline & National hospital \\
\hline
\end{tabular}


Annex 2:- Mapping The Organizations And Their Suppliers.

\begin{tabular}{|c|c|c|c|c|c|c|c|c|c|c|c|c|c|c|c|c|c|c|c|c|c|c|c|c|}
\hline $\begin{array}{l}\text { Or } \\
\text { g, } \\
\text { Ho } \\
\text { sp. } \\
\text { (co } \\
\text { lu } \\
\text { mn } \\
\text { s) } \\
\text { Su } \\
\text { ppl } \\
\text { iers } \\
\text { (ro } \\
\text { ws) }\end{array}$ & 坖 & $\frac{2}{2}$ & 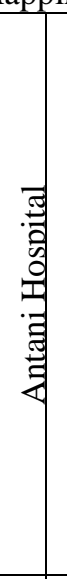 & 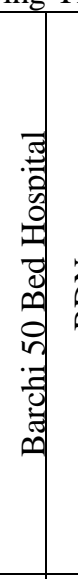 & 光 & 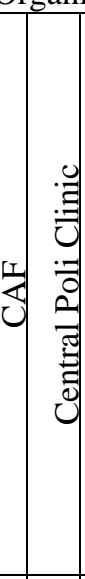 & 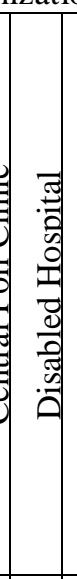 & $\underset{\Sigma}{=}$ & 这 & 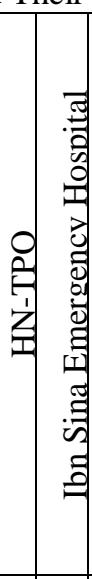 & 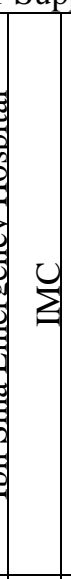 & 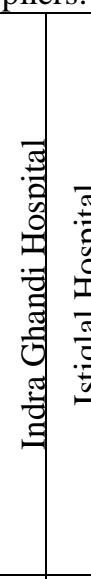 & 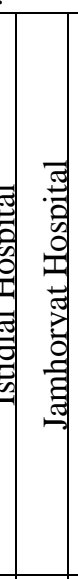 & 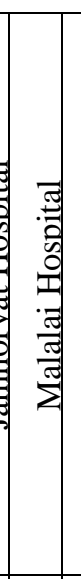 & 3 & $\begin{array}{l}0 \\
0\end{array}$ & ลิ & 3 & 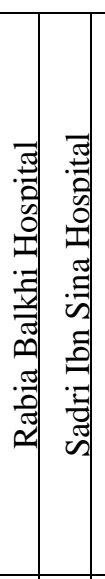 & $\frac{1}{4}$ & 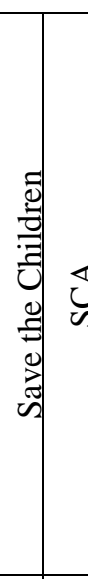 & 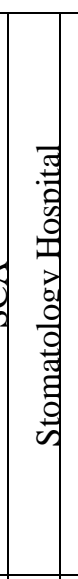 & 3 & 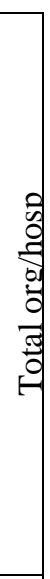 \\
\hline S-1 & & 1 & & & & & & & & 1 & & & & & & & & & & & 1 & & & 3 \\
\hline S-2 & & & & & & & & & & & & & & & & & & & & & 1 & & & 1 \\
\hline S-3 & & & & & & & & & & & & 1 & & & & & & & & & 1 & & & 2 \\
\hline S-4 & & & & & 1 & 1 & & & & & & & & & & & & & & & 1 & & & 2 \\
\hline S-5 & & & & & & & & & & & & & & & & 1 & 1 & & & & & & & 1 \\
\hline S-6 & & 1 & & & & & & & & & & & & & & 1 & 1 & & & & & & & 4 \\
\hline S-7 & & & & & & & & & & & & & & & & & & & & & 1 & & & 1 \\
\hline S-8 & & & & & & & & & & & & & & & & & & & & 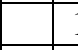 & 1 & & & 2 \\
\hline S-9 & & 1 & & & & & & & & & 1 & & & & 1 & & & & & 1 & & & & 4 \\
\hline $\begin{array}{l}\text { S- } \\
10\end{array}$ & & & & & & & & & 1 & & & & & & & & & & & 1 & 1 & & & 3 \\
\hline $\begin{array}{l}\text { S- } \\
11 \\
\end{array}$ & & & & & & & & & & & & & & & & 1 & & & & & 1 & & & 2 \\
\hline $\begin{array}{l}\text { S- } \\
12\end{array}$ & & & & & & & & & & & & & & & & & & & & & 1 & & & 1 \\
\hline $\begin{array}{l}\mathrm{S}- \\
13\end{array}$ & & & & & & & & & & & & & & & 1 & & & & & & & & & 1 \\
\hline $\begin{array}{l}\text { S- } \\
14\end{array}$ & & & & & 1 & & & & & & & & & & & & & & & & & & & 1 \\
\hline $\begin{array}{l}\text { S- } \\
15\end{array}$ & & & & & & & & & & & & & & & & & 1 & & & & 1 & & & 3 \\
\hline $\begin{array}{l}\text { S- } \\
16\end{array}$ & & 1 & & & & & & & & & & & & & & & & & & & & & & 1 \\
\hline $\begin{array}{l}\text { S- } \\
17\end{array}$ & & & & & & & & 1 & & & & & & & & & & & & & & & & 1 \\
\hline $\begin{array}{l}\text { S- } \\
18 \\
\end{array}$ & & & & & & & & & & & & & & & & & & & & & 1 & & & 1 \\
\hline $\begin{array}{l}\text { S- } \\
19\end{array}$ & & & & & & & & & 1 & 1 & & & & & & & & & & & 1 & & & 2 \\
\hline $\begin{array}{l}\text { S- } \\
20\end{array}$ & & & & & & & & & & & & & & & & & & & & & 1 & & & 1 \\
\hline $\begin{array}{l}\text { S- } \\
21\end{array}$ & & & & & & & & 1 & & & & & & & & & & 1 & & & & & & 2 \\
\hline $\begin{array}{l}\mathrm{S}- \\
22\end{array}$ & & & & & & & 1 & & & & & & & & & & 1 & & & & & & & 2 \\
\hline $\begin{array}{l}\mathrm{S}- \\
23 \\
\end{array}$ & & & & & & & & 1 & & & & & & & & & & 1 & & & 1 & & & 3 \\
\hline $\begin{array}{l}\text { S- } \\
24\end{array}$ & & & & & & & & & 1 & & & & & & & & & & & & 1 & & & 2 \\
\hline S- & 1 & & & & 1 & 1 & & & & & 1 & & & & 1 & 1 & & 1 & & & 1 & & & 8 \\
\hline
\end{tabular}




\begin{tabular}{|c|c|c|c|c|c|c|c|c|c|c|c|c|c|c|c|c|c|c|c|c|c|c|c|c|c|}
\hline 25 & & & & & & & & & & & & & & & & & & & & & & & & & \\
\hline $\begin{array}{l}\text { S- } \\
26\end{array}$ & & & & & & & & & & 1 & & & & & & & & & & & & & & & 1 \\
\hline $\begin{array}{l}\text { S- } \\
27\end{array}$ & & & & & & & & & & & & & & & & & & & & & & 1 & & & 1 \\
\hline $\begin{array}{l}\text { S- } \\
28\end{array}$ & & & & & & & & & & & & & & & & & & & & & & 1 & 1 & & 2 \\
\hline $\begin{array}{l}\text { S- } \\
29\end{array}$ & & & & & & & & & & & & & & & & & & & & & & & 1 & & 1 \\
\hline $\begin{array}{l}\text { S- } \\
30\end{array}$ & & & & & & & & & & & & & & & & & & & & & & & 1 & & 1 \\
\hline $\begin{array}{l}\text { S- } \\
31\end{array}$ & & & & & & & & 1 & & & & & & & & & & & & & & & 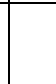 & & 1 \\
\hline $\begin{array}{l}\mathrm{S}- \\
32\end{array}$ & & & & & & & & & & & & & & & & & & 1 & & & & & & & 1 \\
\hline $\begin{array}{l}\text { S- } \\
33\end{array}$ & & & & & & & & & & & & & & & & 1 & & & & & & & & & 1 \\
\hline $\begin{array}{l}\mathrm{S}- \\
34\end{array}$ & & & & & & & & & & & & & & & & & & & & & & & 1 & & 1 \\
\hline $\begin{array}{l}\mathrm{S}- \\
35\end{array}$ & & & & & & & & & & & & & & & & & & & 1 & & & 1 & & & 2 \\
\hline $\begin{array}{l}\text { S- } \\
36\end{array}$ & & 1 & & & & & & & & 1 & & & & & & & & & & & & & 1 & & 3 \\
\hline $\begin{array}{l}\text { S- } \\
37\end{array}$ & & & & & & & & & & & & & & & & & & & & & & & 1 & & 1 \\
\hline $\begin{array}{l}\mathrm{S}- \\
38 \\
\end{array}$ & & & & & & & & & & & & & & & & & & & 1 & & & 1 & & & 2 \\
\hline $\begin{array}{l}\text { S- } \\
39\end{array}$ & 1 & & & & & & & & & & & & & & 1 & & & & & & & & & & 2 \\
\hline $\begin{array}{l}\text { S- } \\
40 \\
\end{array}$ & & & & & & 1 & & & & & & & & & & & & & 1 & & 1 & 1 & 1 & & 5 \\
\hline $\begin{array}{l}\text { S- } \\
41\end{array}$ & & 1 & & & & & & & & & & & & & & & & & & & & 1 & & & 1 \\
\hline $\begin{array}{l}\text { S- } \\
42\end{array}$ & & & & & & & & & 1 & & & & & & & & & & & & & & 1 & & 2 \\
\hline $\begin{array}{l}\mathrm{S}- \\
43\end{array}$ & & & & & & & & & & & & & & & & & & 1 & & & & & & & 1 \\
\hline $\begin{array}{l}\text { S- } \\
44\end{array}$ & & & & & & & & & & & & & & & & & & & & & & 1 & & & 1 \\
\hline $\begin{array}{l}\text { S- } \\
45\end{array}$ & & & & & & & & & & & & & & & 1 & & & & & & 1 & & & & 2 \\
\hline $\begin{array}{l}\mathrm{S}- \\
46\end{array}$ & & & & & & & & & & & & & & & & & & & & & & & 1 & & 1 \\
\hline $\begin{array}{l}\text { S- } \\
47 \\
\end{array}$ & & & & & & & & & & & & & & & & & & & 1 & & & 1 & & & 2 \\
\hline $\begin{array}{l}\mathrm{S}- \\
48\end{array}$ & & & & & & & & & & & & & & & & & & & 1 & & & 1 & & & 2 \\
\hline $\begin{array}{l}\text { S- } \\
49\end{array}$ & & & & & & & & & & & & & & & & & & & 1 & & & 1 & & & 2 \\
\hline $\begin{array}{l}S- \\
50\end{array}$ & & & & & & 1 & & & & 1 & & & & & & & & & & & & & 1 & & 3 \\
\hline $\begin{array}{l}\text { S- } \\
51\end{array}$ & 1 & & & 1 & & & & & & & & & & 1 & & & 1 & & & & & & & & 4 \\
\hline $\begin{array}{l}\mathrm{S}- \\
52\end{array}$ & 1 & & & & & & & & & & & & & & & & & & & & & & & & 1 \\
\hline
\end{tabular}




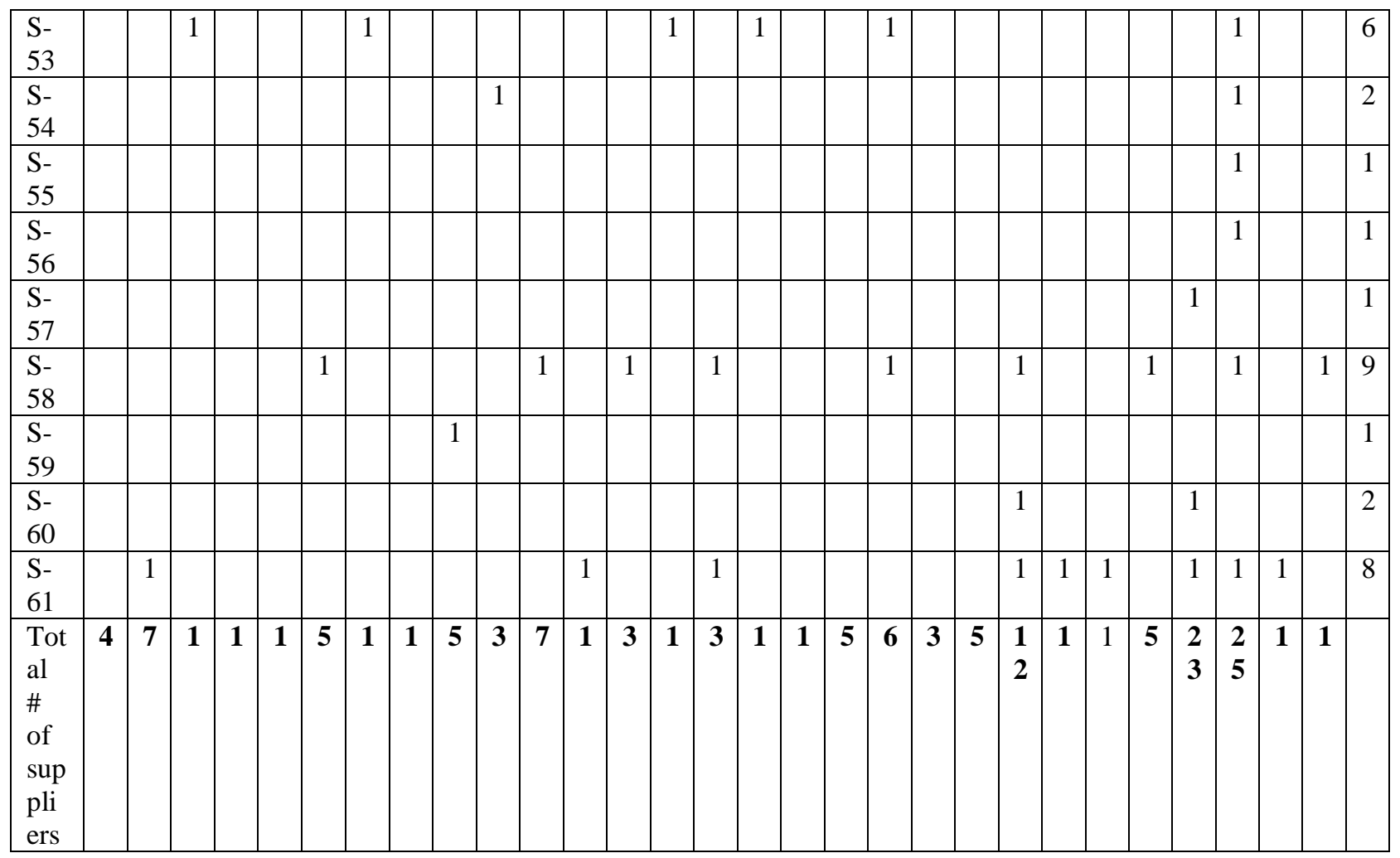

Annex 3:- Suppliers' Performance According To Status Of Meeting Criteria.

Annex 3.1:- Criteria 1-5

\begin{tabular}{|c|c|c|c|c|c|c|c|c|c|c|c|c|c|c|c|c|c|c|c|c|c|}
\hline \multirow[t]{2}{*}{$\begin{array}{l}\text { Serial } \\
\text { no. of } \\
\text { the } \\
\text { suppli } \\
\text { er }\end{array}$} & \multirow[t]{2}{*}{$\begin{array}{l}\text { No. of } \\
\text { organizatio } \\
\text { ns served }\end{array}$} & \multicolumn{4}{|c|}{$\begin{array}{l}\text { 1. Providing } \\
\text { advance } \\
\text { documents }\end{array}$} & \multicolumn{4}{|c|}{$\begin{array}{l}\text { 2. Financial } \\
\text { viability }\end{array}$} & \multicolumn{4}{|c|}{$\begin{array}{l}\text { 3. Qualification } \\
\text { to tender or } \\
\text { procurement }\end{array}$} & \multicolumn{4}{|c|}{$\begin{array}{l}\text { 4. Providing } \\
\text { proof } \\
\text { documents } \\
\text { about product } \\
\text { quality }\end{array}$} & \multicolumn{4}{|c|}{$\begin{array}{lr}5 . & \text { Products } \\
\text { passing } & \text { quality } \\
\text { tests } & \text { upon } \\
\text { arrival } & \end{array}$} \\
\hline & & $\begin{array}{l}\mathrm{F} \\
*\end{array}$ & $\begin{array}{l}\mathrm{P} \\
*\end{array}$ & $\begin{array}{l}\mathrm{N} \\
*\end{array}$ & $\begin{array}{l}\mathrm{U} \\
*\end{array}$ & $\mathrm{~F}$ & $\mathrm{P}$ & $\mathrm{N}$ & $\mathrm{U}$ & $\mathrm{F}$ & $\mathrm{P}$ & $\mathrm{N}$ & $\mathrm{U}$ & $\mathrm{F}$ & $\mathrm{P}$ & $\mathrm{N}$ & $\mathrm{U}$ & $F$ & $\mathrm{P}$ & $\mathrm{N}$ & $\mathrm{U}$ \\
\hline 1 & 3 & 2 & 1 & & & 2 & & & 1 & & 3 & & & 2 & 1 & & & 2 & 1 & & \\
\hline 2 & 1 & 1 & & & & 1 & & & & & 1 & & & 1 & & & & & 1 & & \\
\hline 3 & 2 & 2 & & & & 1 & & & 1 & & 2 & & & 1 & 1 & & & & 2 & & \\
\hline 4 & 2 & 2 & & & & 1 & & 1 & & & 2 & & & 2 & & & & & 2 & & \\
\hline 5 & 1 & 1 & & & & 1 & & & & 1 & & & & & 1 & & & 1 & & & \\
\hline 6 & 4 & 3 & 1 & & & 2 & & & 2 & 2 & 2 & & & 2 & 1 & & 1 & 2 & 1 & 1 & \\
\hline 7 & $\mathbf{1}$ & 1 & & & & 1 & & & & & 1 & & & 1 & & & & & 1 & & \\
\hline 8 & 2 & 2 & & & & 1 & & & 1 & & 2 & & & 1 & 1 & & & & 2 & & \\
\hline 9 & 4 & 3 & 1 & & & 2 & & & 2 & & 4 & & & 4 & & & & 2 & 2 & & \\
\hline 10 & 3 & 1 & 2 & & & 2 & & & 1 & 1 & 2 & & & 2 & 1 & & & & 3 & & \\
\hline 11 & 2 & 1 & 1 & & & & & & 2 & & 2 & & & 1 & 1 & & & & 2 & & \\
\hline 12 & $\mathbf{1}$ & 1 & & & & & & & 1 & & 1 & & & & 1 & & & & 1 & & \\
\hline 13 & 1 & 1 & & & & & & & 1 & & 1 & & & & 1 & & & 1 & & & \\
\hline 14 & $\mathbf{1}$ & 1 & & & & 1 & & & & & 1 & & & 1 & & & & & 1 & & \\
\hline 15 & 3 & 3 & & & & 1 & & & 2 & 1 & 2 & & & 1 & 2 & & & & 2 & 1 & \\
\hline 16 & 1 & 1 & & & & 1 & & & & & 1 & & & 1 & & & & 1 & & & \\
\hline 17 & 1 & 1 & & & & & & & 1 & & 1 & & & 1 & & & & & 1 & & \\
\hline 18 & 1 & 1 & & & & 1 & & & & & 1 & & & 1 & & & & & 1 & & \\
\hline 19 & 2 & 1 & 1 & & & 1 & & & 1 & & 2 & & & 1 & 1 & & & 1 & 1 & & \\
\hline
\end{tabular}




\begin{tabular}{|c|c|c|c|c|c|c|c|c|c|c|c|c|c|c|c|c|c|c|c|c|}
\hline 20 & 1 & 1 & & & & & & 1 & & 1 & & & & 1 & & & & 1 & & \\
\hline 21 & 2 & & 2 & & & 1 & & 1 & 1 & 1 & & & 1 & 1 & & & & 2 & & \\
\hline 22 & 2 & 2 & & & & 1 & & 1 & 2 & & & & 1 & & & 1 & & 1 & 1 & \\
\hline 23 & 3 & 1 & 2 & & & 2 & & 1 & & 3 & & & 3 & & & & & 3 & & \\
\hline 24 & 2 & 1 & 1 & & & 2 & & & & 2 & & & 2 & & & & & 2 & & \\
\hline 25 & 8 & 4 & 4 & & & 4 & 1 & 3 & & 8 & & & 5 & 3 & & & 1 & 6 & 1 & \\
\hline 26 & 1 & & 1 & & & & & 1 & & 1 & & & 1 & & & & 1 & & & \\
\hline 27 & 1 & 1 & & & & 1 & & & & 1 & & & 1 & & & & & 1 & & \\
\hline 28 & 2 & 2 & & & & 1 & & 1 & & 2 & & & 1 & 1 & & & & 2 & & \\
\hline 29 & 1 & 1 & & & & & & 1 & & 1 & & & & 1 & & & & 1 & & \\
\hline 30 & 1 & 1 & & & & & & 1 & & 1 & & & & 1 & & & & 1 & & \\
\hline 31 & 1 & & 1 & & & & & 1 & 1 & & & & & 1 & & & & 1 & & \\
\hline 32 & 1 & 1 & & & & 1 & & & 1 & & & & & & & 1 & & 1 & & \\
\hline 33 & 1 & & 1 & & & & & 1 & & 1 & & & 1 & & & & & 1 & & \\
\hline 34 & 1 & & 1 & & & & & 1 & & 1 & & & & 1 & & & & 1 & & \\
\hline 35 & 2 & 1 & 1 & & & 2 & & & 1 & 1 & & & 2 & & & & 1 & 1 & & \\
\hline 36 & 3 & 2 & 1 & & & 2 & & 1 & & 3 & & & 2 & 1 & & & 2 & 1 & & \\
\hline 37 & 1 & 1 & & & & & & 1 & & 1 & & & & 1 & & & & 1 & & \\
\hline 38 & 2 & 1 & 1 & & & 2 & & & & 2 & & & 2 & & & & & 2 & & \\
\hline 39 & 2 & 1 & 1 & & & & & 2 & 1 & 1 & & & & 1 & & 1 & 1 & & 1 & \\
\hline 40 & 5 & 4 & 1 & & & 2 & 1 & 2 & & 5 & & & 4 & 1 & & & & 5 & & \\
\hline 41 & 2 & 2 & & & & 2 & & & 1 & 1 & & & 2 & & & & 1 & 1 & & \\
\hline 42 & 2 & 1 & 1 & & & 1 & & 1 & & 2 & & & & 2 & & & & 2 & & \\
\hline 43 & 1 & 1 & & & & & & 1 & 1 & & & & & & & 1 & & & 1 & \\
\hline 44 & 1 & 1 & & & & 1 & & & & 1 & & & 1 & & & & & 1 & & \\
\hline 45 & 2 & 2 & & & & & & 2 & & 2 & & & & 2 & & & 1 & 1 & & \\
\hline 46 & 1 & 1 & & & & & & 1 & & 1 & & & & 1 & & & & 1 & & \\
\hline 47 & 2 & 1 & 1 & & & 2 & & & & 2 & & & 2 & & & & & 2 & & \\
\hline 48 & 2 & 1 & 1 & & & 2 & & & & 2 & & & 2 & & & & & 2 & & \\
\hline 49 & 2 & 1 & 1 & & & 2 & & & & 2 & & & 2 & & & & & 2 & & \\
\hline 50 & 3 & 1 & 2 & & & 1 & 1 & 1 & & 3 & & & 2 & 1 & & & 1 & 2 & & \\
\hline 51 & 4 & 3 & 1 & & & 3 & & 1 & 2 & 2 & & & 1 & 3 & & & 1 & 2 & 1 & \\
\hline 52 & 1 & 1 & & & & 1 & & & & 1 & & & & 1 & & & & & 1 & \\
\hline 53 & 6 & 3 & 3 & & & 4 & & 2 & 4 & 2 & & & 2 & 4 & & & & 6 & & \\
\hline 54 & 2 & & 2 & & & 1 & & 1 & & 2 & & & & 2 & & & & 2 & & \\
\hline 55 & 1 & 1 & & & & & & 1 & & 1 & & & & 1 & & & & 1 & & \\
\hline 56 & 1 & 1 & & & & & & 1 & & 1 & & & & 1 & & & & 1 & & \\
\hline 57 & 1 & 1 & & & & 1 & & & & 1 & & & 1 & & & & & 1 & & \\
\hline 58 & 9 & 3 & 6 & & & 5 & 1 & 3 & 1 & 8 & & & 6 & 3 & & & 1 & 8 & & \\
\hline 59 & 1 & 1 & & & & & & 1 & & 1 & & & 1 & & & & & 1 & & \\
\hline 60 & 2 & 1 & 1 & & & 2 & & & & 2 & & & 2 & & & & & 2 & & \\
\hline \multirow[t]{2}{*}{61} & 9 & 4 & 5 & & & 8 & & 1 & 4 & 5 & & & 8 & 1 & & & 1 & 8 & & \\
\hline & 134 & $\begin{array}{l}8 \\
5\end{array}$ & $\begin{array}{l}4 \\
9\end{array}$ & 0 & 0 & $\begin{array}{l}7 \\
6\end{array}$ & 5 & $\begin{array}{l}5 \\
3\end{array}$ & $\begin{array}{l}2 \\
5\end{array}$ & $\begin{array}{l}10 \\
9\end{array}$ & 0 & 0 & $\begin{array}{l}8 \\
1\end{array}$ & $\begin{array}{l}4 \\
8\end{array}$ & 0 & 5 & $\begin{array}{l}2 \\
2\end{array}$ & $\begin{array}{l}10 \\
4\end{array}$ & 8 & 0 \\
\hline
\end{tabular}

*F: Fully met, P: Partly met, N: Did not meet (No), U: Not known (unknown) 
Annex 3.2. Criteria 6-10

\begin{tabular}{|c|c|c|c|c|c|c|c|c|c|c|c|c|c|c|c|c|c|c|c|c|c|}
\hline \multirow[t]{2}{*}{$\begin{array}{l}\text { Serial } \\
\text { no. of } \\
\text { the } \\
\text { suppli } \\
\text { er }\end{array}$} & \multirow[t]{2}{*}{$\begin{array}{l}\text { No. of } \\
\text { organizatio } \\
\text { ns served }\end{array}$} & \multicolumn{4}{|c|}{$\begin{array}{l}\text { 6. Insurance and } \\
\text { shipment } \\
\text { according to } \\
\text { contract financial } \\
\text { terms }\end{array}$} & \multicolumn{4}{|c|}{$\begin{array}{l}7 . \quad \text { Invoice } \\
\text { compliance } \\
\text { with contract } \\
\text { pricing terms }\end{array}$} & \multicolumn{4}{|c|}{$\begin{array}{l}\text { 8. Meeting } \\
\text { delivery time } \\
\text { according to } \\
\text { the contract } \\
\text { terms }\end{array}$} & \multicolumn{4}{|c|}{$\begin{array}{l}\text { 9. Shipping } \\
\text { correct } \\
\text { products }\end{array}$} & \multicolumn{4}{|c|}{$\begin{array}{l}\text { 10. Delivering } \\
\text { the quantities } \\
\text { according to } \\
\text { the contract } \\
\text { terms }\end{array}$} \\
\hline & & $\mathrm{F}^{*}$ & $\begin{array}{l}\mathrm{P} \\
*\end{array}$ & $\begin{array}{l}\mathrm{N} \\
*\end{array}$ & $\begin{array}{l}\mathrm{U} \\
*\end{array}$ & $\mathrm{~F}$ & $\mathrm{P}$ & $\mathrm{N}$ & $\mathrm{U}$ & $\mathrm{F}$ & $\mathrm{P}$ & $\mathrm{N}$ & $\mathrm{U}$ & $\mathrm{F}$ & $P$ & $\mathrm{~N}$ & $\mathrm{U}$ & $\mathrm{F}$ & $\mathrm{P}$ & $\mathrm{N}$ & $\mathrm{U}$ \\
\hline 1 & 3 & 3 & & & & 2 & & & 1 & 2 & 1 & & & 3 & & & & 2 & 1 & & \\
\hline 2 & 1 & 1 & & & & 1 & & & & 1 & & & & 1 & & & & 1 & & & \\
\hline 3 & 2 & 2 & & & & 2 & & & & 2 & & & & 2 & & & & 2 & & & \\
\hline 4 & 2 & 2 & & & & 2 & & & & 2 & & & & 2 & & & & 2 & & & \\
\hline 5 & 1 & 1 & & & & 1 & & & & & & 1 & & 1 & & & & 1 & & & \\
\hline 6 & 4 & 3 & & & 1 & 4 & & & & 2 & & & 2 & 3 & & & 1 & 4 & & & \\
\hline 7 & $\mathbf{1}$ & 1 & & & & 1 & & & & 1 & & & & 1 & & & & 1 & & & \\
\hline 8 & 2 & 2 & & & & 2 & & & & 2 & & & & 2 & & & & 2 & & & \\
\hline 9 & 4 & 3 & & & 1 & 4 & & & & 4 & & & & 4 & & & & 3 & & & 1 \\
\hline 10 & 3 & 2 & & & 1 & 2 & & & 1 & 3 & & & & 3 & & & & 3 & & & \\
\hline 11 & 2 & 2 & & & & 2 & & & & 2 & & & & 2 & & & & 2 & & & \\
\hline 12 & 1 & 1 & & & & 1 & & & & 1 & & & & 1 & & & & 1 & & & \\
\hline 13 & 1 & & & & 1 & 1 & & & & 1 & & & & 1 & & & & 1 & & & \\
\hline 14 & 1 & & & & 1 & 1 & & & & 1 & & & & 1 & & & & 1 & & & \\
\hline 15 & 3 & 2 & & & 1 & 3 & & & & 2 & & & 1 & 2 & & & 1 & 3 & & & \\
\hline 16 & $\mathbf{1}$ & 1 & & & & 1 & & & & 1 & & & & 1 & & & & 1 & & & \\
\hline 17 & 1 & 1 & & & & 1 & & & & 1 & & & & 1 & & & & 1 & & & \\
\hline 18 & 1 & 1 & & & & 1 & & & & 1 & & & & 1 & & & & 1 & & & \\
\hline 19 & 2 & 2 & & & & 1 & & & 1 & 1 & 1 & & & 2 & & & & 1 & 1 & & \\
\hline 20 & 1 & 1 & & & & 1 & & & & 1 & & & & 1 & & & & 1 & & & \\
\hline 21 & 2 & 2 & & & & 2 & & & & 2 & & & & 2 & & & & 2 & & & \\
\hline 22 & 2 & 1 & & & 1 & 2 & & & & 1 & & & 1 & 1 & & & 1 & 2 & & & \\
\hline 23 & 3 & 3 & & & & 3 & & & & 3 & & & & 3 & & & & 3 & & & \\
\hline 24 & 2 & 2 & & & & 1 & & & 1 & 1 & 1 & & & 2 & & & & 1 & 1 & & \\
\hline 25 & 8 & 7 & & & 1 & 8 & & & & 8 & & & & 8 & & & & 7 & & & 1 \\
\hline 26 & $\mathbf{1}$ & 1 & & & & & & & 1 & & 1 & & & 1 & & & & & 1 & & \\
\hline 27 & 1 & 1 & & & & 1 & & & & 1 & & & & 1 & & & & 1 & & & \\
\hline 28 & 2 & 2 & & & & 2 & & & & 2 & & & & 2 & & & & 2 & & & \\
\hline 29 & 1 & 1 & & & & 1 & & & & 1 & & & & 1 & & & & 1 & & & \\
\hline 30 & $\mathbf{1}$ & 1 & & & & 1 & & & & 1 & & & & 1 & & & & 1 & & & \\
\hline 31 & $\mathbf{1}$ & 1 & & & & 1 & & & & 1 & & & & 1 & & & & 1 & & & \\
\hline 32 & 1 & 1 & & & & 1 & & & & 1 & & & & 1 & & & & 1 & & & \\
\hline 33 & 1 & 1 & & & & 1 & & & & 1 & & & & 1 & & & & 1 & & & \\
\hline 34 & $\mathbf{1}$ & 1 & & & & 1 & & & & 1 & & & & 1 & & & & 1 & & & \\
\hline 35 & 2 & 2 & & & & 2 & & & & 2 & & & & 2 & & & & 2 & & & \\
\hline 36 & 3 & 3 & & & & 2 & & & 1 & 2 & 1 & & & 3 & & & & 2 & 1 & & \\
\hline $\begin{array}{l}37 \\
\end{array}$ & $\mathbf{1}$ & 1 & & & & 1 & & & & 1 & & & & 1 & & & & 1 & & & \\
\hline 38 & 2 & 2 & & & & 2 & & & & 2 & & & & 2 & & & & 2 & & & \\
\hline 39 & 2 & 1 & & & 1 & 1 & & & 1 & 2 & & & & 2 & & & & 2 & & & \\
\hline 40 & 5 & 5 & & & & 5 & & & & 5 & & & & 5 & & & & 5 & & & \\
\hline 41 & 2 & 2 & & & & 2 & & & & 2 & & & & 2 & & & & 2 & & & \\
\hline 42 & 2 & 1 & & & 1 & 1 & & & 1 & 2 & & & & 2 & & & & 2 & & & \\
\hline 43 & 1 & & & & 1 & 1 & & & & & & & 1 & & & & 1 & 1 & & & \\
\hline 44 & 1 & 1 & & & & 1 & & & & 1 & & & & 1 & & & & 1 & & & \\
\hline 45 & 2 & 1 & & & 1 & 1 & & & 1 & 1 & 1 & & & 2 & & & & 2 & & & \\
\hline 46 & 1 & 1 & & & & 1 & & & & 1 & & & & 1 & & & & 1 & & & \\
\hline
\end{tabular}




\begin{tabular}{|c|c|c|c|c|c|c|c|c|c|c|c|c|c|c|c|c|c|c|c|c|c|}
\hline 47 & 2 & 2 & & & & 2 & & & & 2 & & & & 2 & & & & 2 & & & \\
\hline 48 & 2 & 2 & & & & 2 & & & & 2 & & & & 2 & & & & 2 & & & \\
\hline 49 & 2 & 2 & & & & 2 & & & & 2 & & & & 2 & & & & 2 & & & \\
\hline 50 & 3 & 3 & & & & 2 & & & 1 & 2 & 1 & & & 3 & & & & 2 & 1 & & \\
\hline 51 & 4 & 4 & & & & 4 & & & & 3 & & 1 & & 4 & & & & 4 & & & \\
\hline 52 & $\mathbf{1}$ & 1 & & & & 1 & & & & 1 & & & & 1 & & & & 1 & & & \\
\hline 53 & 6 & 6 & & & & 6 & & & & 6 & & & & 6 & & & & 6 & & & \\
\hline 54 & 2 & 1 & & & 1 & 1 & & & 1 & 2 & & & & 2 & & & & 2 & & & \\
\hline 55 & $\mathbf{1}$ & 1 & & & & 1 & & & & 1 & & & & 1 & & & & 1 & & & \\
\hline 56 & $\mathbf{1}$ & 1 & & & & 1 & & & & 1 & & & & 1 & & & & 1 & & & \\
\hline 57 & $\mathbf{1}$ & 1 & & & & 1 & & & & 1 & & & & 1 & & & & 1 & & & \\
\hline 58 & 9 & 9 & & & & 7 & & & 2 & 8 & 1 & & & 9 & & & & 7 & 1 & & 1 \\
\hline 59 & $\mathbf{1}$ & 1 & & & & 1 & & & & 1 & & & & 1 & & & & 1 & & & \\
\hline 60 & 2 & 2 & & & & 2 & & & & 2 & & & & 2 & & & & 2 & & & \\
\hline 61 & 9 & 9 & & & & 5 & & & 4 & 9 & & & & 9 & & & & 9 & & & \\
\hline Total & 134 & $\begin{array}{l}12 \\
1\end{array}$ & 0 & 0 & 13 & $\begin{array}{l}11 \\
7\end{array}$ & 0 & 0 & $\begin{array}{l}1 \\
7\end{array}$ & $\begin{array}{l}11 \\
9\end{array}$ & 8 & 2 & 5 & $\begin{array}{l}13 \\
0\end{array}$ & 0 & 0 & 4 & \begin{tabular}{|l|l}
12 \\
4
\end{tabular} & 7 & 0 & 3 \\
\hline
\end{tabular}

*F: Fully met, P: Partly met, N: Did not meet (No), U: Not known (unknown)

Annex 3.3:- Criteria 11-14 and Average Scores.

\begin{tabular}{|c|c|c|c|c|c|c|c|c|c|c|c|c|c|c|c|c|c|c|c|c|c|c|c|c|}
\hline \multirow[t]{2}{*}{$\begin{array}{l}\text { Seria } \\
1 \text { no. } \\
\text { of } \\
\text { the } \\
\text { supp } \\
\text { liers }\end{array}$} & \multirow[t]{2}{*}{$\begin{array}{l}\text { No. of } \\
\text { organiz } \\
\text { ations } \\
\text { served }\end{array}$} & \multicolumn{4}{|c|}{$\begin{array}{l}\text { 11. Delivering } \\
\text { products that } \\
\text { comply with } \\
\text { contract } \\
\text { terms for } \\
\text { remaining } \\
\text { shelf life }\end{array}$} & \multicolumn{4}{|c|}{$\begin{array}{l}12 . \\
\text { Providing } \\
\text { correct } \\
\text { packaging }\end{array}$} & \multicolumn{4}{|c|}{$\begin{array}{l}13 . \\
\text { Providing } \\
\text { correct } \\
\text { labeling }\end{array}$} & \multicolumn{4}{|c|}{$\begin{array}{l}\text { 14. Active } \\
\text { update } \\
\text { about order } \\
\text { Status }\end{array}$} & \multicolumn{4}{|c|}{ Total } & \multirow[t]{2}{*}{$\begin{array}{l}\mathbf{T} \\
\mathbf{o} \\
\mathbf{t} \\
\mathbf{a l} \\
\mathrm{s} \\
\mathrm{c} \\
\mathbf{o} \\
\mathbf{r} \\
\mathrm{e}\end{array}$} & \multirow{2}{*}{ 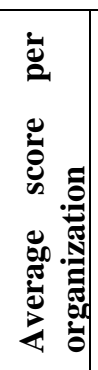 } & \multirow[t]{2}{*}{ 气्: } \\
\hline & & $\begin{array}{l}\mathbf{F} \\
*\end{array}$ & $\begin{array}{l}\mathbf{P} \\
*\end{array}$ & $\begin{array}{l}\mathbf{N} \\
*\end{array}$ & $\begin{array}{l}\mathbf{U} \\
*\end{array}$ & $\mathbf{F}$ & \begin{tabular}{l|l|}
$\mathbf{P}$ \\
\end{tabular} & $\mathbf{N}$ & $\mathbf{U}$ & F & $\mathbf{P}$ & $\mathbf{N}$ & $\mathbf{U}$ & $F$ & $\mathbf{P}$ & $\mathbf{N}$ & $\mathbf{U}$ & $\mathbf{F}$ & $\mathbf{P}$ & $\mathbf{N}$ & $\mathbf{U}$ & & & \\
\hline 1 & 3 & 3 & & & & 3 & & & & 3 & & & & 2 & 1 & & & 31 & 9 & 0 & 2 & $\begin{array}{l}7 \\
1\end{array}$ & $\begin{array}{l}23 . \\
67\end{array}$ & 6 \\
\hline 2 & 1 & 1 & & & & 1 & & & & 1 & & & & 1 & & & & 12 & 2 & 0 & 0 & $\begin{array}{l}2 \\
6 \\
\end{array}$ & $\begin{array}{l}26 . \\
00\end{array}$ & 2 \\
\hline 3 & 2 & 2 & & & & 2 & & & & 2 & & & & 2 & & & & 22 & 5 & 0 & 1 & $\begin{array}{l}4 \\
9\end{array}$ & $\begin{array}{l}24 . \\
50\end{array}$ & 4 \\
\hline 4 & 2 & 2 & & & & 2 & & & & 2 & & & & 1 & & 1 & & 22 & 4 & 2 & 0 & $\begin{array}{l}4 \\
6\end{array}$ & $\begin{array}{l}23 . \\
00\end{array}$ & 7 \\
\hline 5 & 1 & 1 & & & & & & & 1 & 1 & & & & & & 1 & & 10 & 1 & 2 & 1 & $\begin{array}{l}1 \\
9\end{array}$ & $\begin{array}{l}19 . \\
00\end{array}$ & $\begin{array}{l}2 \\
2\end{array}$ \\
\hline 6 & 4 & 4 & & & & 3 & & & 1 & 3 & & & 1 & 1 & & 3 & & 38 & 5 & 4 & 9 & $\begin{array}{l}7 \\
7\end{array}$ & $\begin{array}{l}19 . \\
25\end{array}$ & $\begin{array}{l}2 \\
1\end{array}$ \\
\hline 7 & 1 & 1 & & & & 1 & & & & 1 & & & & 1 & & & & 12 & 2 & 0 & 0 & $\begin{array}{l}2 \\
6\end{array}$ & $\begin{array}{l}26 . \\
00\end{array}$ & 2 \\
\hline 8 & 2 & 2 & & & & 2 & & & & 2 & & & & 2 & & & & 22 & 5 & 0 & 1 & $\begin{array}{l}4 \\
9\end{array}$ & $\begin{array}{l}24 . \\
50\end{array}$ & 4 \\
\hline 9 & 4 & 4 & & & & 3 & & & 1 & 2 & & & 2 & 2 & 1 & & 1 & 40 & 8 & 0 & 8 & $\begin{array}{l}8 \\
8\end{array}$ & $\begin{array}{l}22 . \\
00\end{array}$ & $\begin{array}{l}1 \\
1\end{array}$ \\
\hline 10 & 3 & 3 & & & & 3 & & & & 2 & & & 1 & 3 & & & & 30 & 8 & 0 & 4 & $\begin{array}{l}6 \\
8\end{array}$ & $\begin{array}{l}22 . \\
67\end{array}$ & 9 \\
\hline 11 & 2 & 2 & & & & 2 & & & & 2 & & & & 1 & & 1 & & 19 & 6 & 1 & 2 & $\begin{array}{l}4 \\
3\end{array}$ & $\begin{array}{l}21 . \\
50\end{array}$ & $\begin{array}{l}1 \\
4\end{array}$ \\
\hline 12 & 1 & 1 & & & & 1 & & & & 1 & & & & 1 & & & & 10 & 3 & 0 & 1 & $\begin{array}{l}2 \\
3\end{array}$ & $\begin{array}{l}23 . \\
00\end{array}$ & 7 \\
\hline 13 & 1 & 1 & & & & & & & 1 & & & & 1 & & & 1 & & 7 & 2 & 1 & 4 & 1 & 15. & 2 \\
\hline
\end{tabular}




\begin{tabular}{|c|c|c|c|c|c|c|c|c|c|c|c|c|c|c|c|c|c|c|c|c|c|}
\hline & & & & & & & & & & & & & & & & & & & 5 & 00 & 5 \\
\hline 14 & $\mathbf{1}$ & 1 & & & 1 & & & 1 & & & & & 1 & & 10 & 2 & 1 & 1 & \begin{tabular}{|l|}
2 \\
1
\end{tabular} & $\begin{array}{l}21 . \\
00\end{array}$ & $\begin{array}{l}1 \\
5\end{array}$ \\
\hline 15 & 3 & 3 & & & 3 & & & 2 & & 1 & 2 & & & 1 & 28 & 6 & 1 & 7 & $\begin{array}{l}6 \\
1\end{array}$ & $\begin{array}{l}20 . \\
33\end{array}$ & $\begin{array}{l}1 \\
8 \\
\end{array}$ \\
\hline 16 & 1 & 1 & & & 1 & & & 1 & & & 1 & & & & 13 & 1 & 0 & 0 & $\begin{array}{l}2 \\
7\end{array}$ & $\begin{array}{l}27 . \\
00\end{array}$ & 1 \\
\hline 17 & 1 & 1 & & & 1 & & & 1 & & & & & 1 & & 10 & 2 & 1 & 1 & $\begin{array}{l}2 \\
1\end{array}$ & $\begin{array}{l}21 . \\
00\end{array}$ & $\begin{array}{l}1 \\
5\end{array}$ \\
\hline 18 & 1 & 1 & & & 1 & & & 1 & & & 1 & & & & 12 & 2 & 0 & 0 & $\begin{array}{l}2 \\
6\end{array}$ & $\begin{array}{l}26 . \\
00\end{array}$ & 2 \\
\hline 19 & 2 & 2 & & & 2 & & & 2 & & & 1 & 1 & & & 18 & 8 & 0 & 2 & $\begin{array}{l}4 \\
4\end{array}$ & $\begin{array}{l}22 . \\
00\end{array}$ & $\begin{array}{l}1 \\
1\end{array}$ \\
\hline 20 & 1 & 1 & & & 1 & & & 1 & & & 1 & & & & 10 & 3 & 0 & 1 & $\begin{array}{l}2 \\
3\end{array}$ & $\begin{array}{l}23 . \\
00\end{array}$ & 7 \\
\hline 21 & 2 & 2 & & & 2 & & & 1 & & 1 & & & 1 & 1 & 18 & 6 & 1 & 3 & $\begin{array}{l}4 \\
1\end{array}$ & $\begin{array}{l}20 . \\
50\end{array}$ & $\begin{array}{l}1 \\
7\end{array}$ \\
\hline 22 & 2 & 2 & & & 2 & & & 1 & & 1 & & & 1 & 1 & 18 & 1 & 2 & 7 & $\begin{array}{l}3 \\
5\end{array}$ & $\begin{array}{l}17 . \\
50\end{array}$ & $\begin{array}{l}2 \\
3 \\
\end{array}$ \\
\hline 23 & 3 & 3 & & & 3 & & & 2 & & 1 & 1 & & 1 & 1 & 30 & 8 & 1 & 3 & $\begin{array}{l}6 \\
7\end{array}$ & $\begin{array}{l}22 . \\
33\end{array}$ & $\begin{array}{l}1 \\
0\end{array}$ \\
\hline 24 & 2 & 2 & & & 2 & & & 2 & & & 1 & 1 & & & 19 & 8 & 0 & 1 & $\begin{array}{l}4 \\
6\end{array}$ & $\begin{array}{l}23 . \\
00\end{array}$ & 7 \\
\hline 25 & 8 & 8 & & & 7 & 1 & & 6 & & 2 & 2 & 1 & 5 & & 75 & $\begin{array}{l}2 \\
3\end{array}$ & 7 & 7 & $\begin{array}{l}1 \\
6 \\
6\end{array}$ & $\begin{array}{l}20 . \\
75\end{array}$ & $\begin{array}{l}1 \\
6\end{array}$ \\
\hline 26 & 1 & 1 & & & 1 & & & 1 & & & 1 & & & & 8 & 4 & 0 & 2 & $\begin{array}{l}2 \\
0\end{array}$ & $\begin{array}{l}20 . \\
00\end{array}$ & $\begin{array}{l}1 \\
9\end{array}$ \\
\hline 27 & 1 & 1 & & & 1 & & & 1 & & & 1 & & & & 12 & 2 & 0 & 0 & \begin{tabular}{|l|}
2 \\
6
\end{tabular} & $\begin{array}{l}26 . \\
00\end{array}$ & 2 \\
\hline 28 & 2 & 2 & & & 2 & & & 2 & & & 2 & & & & 22 & 5 & 0 & 1 & $\begin{array}{l}4 \\
9\end{array}$ & $\begin{array}{l}24 . \\
50\end{array}$ & 4 \\
\hline 29 & 1 & 1 & & & 1 & & & 1 & & & 1 & & & & 10 & 3 & 0 & 1 & $\begin{array}{l}2 \\
3 \\
\end{array}$ & $\begin{array}{l}23 . \\
00\end{array}$ & 7 \\
\hline 30 & 1 & 1 & & & 1 & & & 1 & & & 1 & & & & 10 & 3 & 0 & 1 & $\begin{array}{l}2 \\
3\end{array}$ & $\begin{array}{l}23 . \\
00\end{array}$ & 7 \\
\hline 31 & 1 & 1 & & & 1 & & & & & 1 & & & & 1 & 8 & 3 & 0 & 3 & $\begin{array}{l}1 \\
9\end{array}$ & $\begin{array}{l}19 . \\
00\end{array}$ & \begin{tabular}{|l}
2 \\
2
\end{tabular} \\
\hline 32 & 1 & 1 & & & 1 & & & 1 & & & 1 & & & & 12 & 1 & 0 & 1 & $\begin{array}{l}2 \\
5 \\
\end{array}$ & $\begin{array}{l}25 . \\
00\end{array}$ & 3 \\
\hline 33 & 1 & 1 & & & 1 & & & 1 & & & & & 1 & & 9 & 3 & 1 & 1 & $\begin{array}{l}2 \\
0\end{array}$ & $\begin{array}{l}20 . \\
00\end{array}$ & $\begin{array}{l}2 \\
0\end{array}$ \\
\hline 34 & 1 & 1 & & & 1 & & & 1 & & & 1 & & & & 9 & 4 & 0 & 1 & $\begin{array}{l}2 \\
2\end{array}$ & $\begin{array}{l}22 . \\
00\end{array}$ & $\begin{array}{l}1 \\
1\end{array}$ \\
\hline 35 & 2 & 2 & & & 2 & & & 2 & & & 1 & & 1 & & 24 & 3 & 1 & 0 & \begin{tabular}{|l}
5 \\
0
\end{tabular} & $\begin{array}{l}25 . \\
00\end{array}$ & 3 \\
\hline 36 & 3 & 3 & & & 3 & & & 3 & & & 2 & 1 & & & 31 & 9 & 0 & 2 & $\begin{array}{l}7 \\
1 \\
\end{array}$ & $\begin{array}{l}23 . \\
67\end{array}$ & 6 \\
\hline 37 & 1 & 1 & & & 1 & & & 1 & & & 1 & & & & 10 & 3 & 0 & 1 & $\begin{array}{l}2 \\
3 \\
\end{array}$ & $\begin{array}{l}23 . \\
00\end{array}$ & 7 \\
\hline 38 & 2 & 2 & & & 2 & & & 2 & & & 1 & & 1 & & 22 & 5 & 1 & 0 & $\begin{array}{l}44 \\
8\end{array}$ & $\begin{array}{l}24 . \\
00\end{array}$ & 5 \\
\hline 39 & 2 & 2 & & & 1 & 1 & & 1 & & 1 & & & 1 & 1 & 15 & 4 & 2 & 7 & $\begin{array}{l}3 \\
2\end{array}$ & $\begin{array}{l}16 . \\
00\end{array}$ & \begin{tabular}{|l|}
2 \\
4
\end{tabular} \\
\hline 40 & 5 & 5 & & & 5 & & & 5 & & & 3 & & 2 & & 53 & 1 & 3 & 2 & 1 & 23. & 7 \\
\hline
\end{tabular}




\begin{tabular}{|c|c|c|c|c|c|c|c|c|c|c|c|c|c|c|c|c|c|c|c|c|c|c|c|}
\hline & & & & & & & & & & & & & & & & & & 2 & & & $\begin{array}{l}1 \\
5\end{array}$ & 00 & \\
\hline 41 & 2 & 2 & & & 2 & & & & 2 & & & & 2 & & & & 26 & 2 & 0 & 0 & \begin{tabular}{|l|}
5 \\
4
\end{tabular} & $\begin{array}{l}27 . \\
00\end{array}$ & 1 \\
\hline 42 & 2 & 2 & & & 2 & & & & 1 & & & 1 & 2 & & & & 17 & 7 & 0 & 4 & \begin{tabular}{|l|}
4 \\
1
\end{tabular} & $\begin{array}{l}20 . \\
50\end{array}$ & $\begin{array}{l}1 \\
7\end{array}$ \\
\hline 43 & 1 & 1 & & & 1 & & & & & & & 1 & & & & 1 & 6 & 0 & 1 & 7 & $\begin{array}{l}1 \\
1\end{array}$ & $\begin{array}{l}11 . \\
00\end{array}$ & $\begin{array}{l}2 \\
6\end{array}$ \\
\hline 44 & 1 & 1 & & & 1 & & & & 1 & & & & 1 & & & & 12 & 2 & 0 & 0 & $\begin{array}{l}2 \\
6\end{array}$ & $\begin{array}{l}26 . \\
00\end{array}$ & 2 \\
\hline 45 & 2 & 2 & & & 1 & 1 & & & 1 & & 1 & & 1 & & 1 & & 15 & 7 & 2 & 4 & $\begin{array}{l}3 \\
5\end{array}$ & $\begin{array}{l}17 . \\
50\end{array}$ & $\begin{array}{l}2 \\
3\end{array}$ \\
\hline 46 & 1 & 1 & & & 1 & & & & 1 & & & & 1 & & & & 10 & 3 & 0 & 1 & \begin{tabular}{|l}
2 \\
3
\end{tabular} & $\begin{array}{l}23 . \\
00\end{array}$ & 7 \\
\hline 47 & 2 & 2 & & & 2 & & & & 2 & & & & 1 & & 1 & & 22 & 5 & 1 & 0 & \begin{tabular}{|l|}
4 \\
8
\end{tabular} & $\begin{array}{l}24 . \\
00\end{array}$ & 5 \\
\hline 48 & 2 & 2 & & & 2 & & & & 2 & & & & 1 & & 1 & & 22 & 5 & 1 & 0 & \begin{tabular}{|l|}
4 \\
8
\end{tabular} & $\begin{array}{l}24 . \\
00\end{array}$ & 5 \\
\hline 49 & 2 & 2 & & & 2 & & & & 2 & & & & 1 & & 1 & & 22 & 5 & 1 & 0 & $\begin{array}{l}4 \\
8 \\
\end{array}$ & $\begin{array}{l}24 . \\
00\end{array}$ & 5 \\
\hline 50 & 3 & 3 & & & 3 & & & & 3 & & & & 1 & 1 & 1 & & 27 & $\begin{array}{l}1 \\
1\end{array}$ & 2 & 2 & \begin{tabular}{|l|}
6 \\
3
\end{tabular} & $\begin{array}{l}21 . \\
00\end{array}$ & $\begin{array}{l}1 \\
5\end{array}$ \\
\hline 51 & 4 & 4 & & & 3 & & & 1 & 4 & & & & 1 & 1 & 2 & & 41 & 9 & 4 & 2 & $\begin{array}{l}8 \\
7 \\
\end{array}$ & $\begin{array}{l}21 . \\
75 \\
\end{array}$ & $\begin{array}{l}1 \\
2 \\
\end{array}$ \\
\hline 52 & 1 & 1 & & & 1 & & & & 1 & & & & & & & 1 & 10 & 2 & 1 & 1 & $\begin{array}{l}2 \\
1\end{array}$ & $\begin{array}{l}21 . \\
00\end{array}$ & $\begin{array}{l}1 \\
5\end{array}$ \\
\hline 53 & 6 & 6 & & & 6 & & & & 6 & & & & 2 & & 4 & & 63 & $\begin{array}{l}1 \\
5\end{array}$ & 4 & 2 & $\begin{array}{l}1 \\
3 \\
7\end{array}$ & $\begin{array}{l}22 . \\
83\end{array}$ & 8 \\
\hline 54 & 2 & 2 & & & 2 & & & & 1 & & & 1 & 2 & & & & 16 & 8 & 0 & 4 & $\begin{array}{l}4 \\
0\end{array}$ & $\begin{array}{l}20 . \\
00\end{array}$ & \begin{tabular}{|l|}
2 \\
0 \\
\end{tabular} \\
\hline 55 & 1 & 1 & & & 1 & & & & 1 & & & & 1 & & & & 10 & 3 & 0 & 1 & $\begin{array}{l}2 \\
3\end{array}$ & $\begin{array}{l}23 . \\
00\end{array}$ & 7 \\
\hline 56 & 1 & 1 & & & 1 & & & & 1 & & & & 1 & & & & 10 & 3 & 0 & 1 & $\begin{array}{l}2 \\
3 \\
\end{array}$ & $\begin{array}{l}23 . \\
00\end{array}$ & 7 \\
\hline 57 & 1 & 1 & & & 1 & & & & 1 & & & & 1 & & & & 12 & 2 & 0 & 0 & $\begin{array}{l}2 \\
6\end{array}$ & $\begin{array}{l}26 . \\
00\end{array}$ & 2 \\
\hline 58 & 9 & 9 & & & 9 & & & & 8 & & & 1 & 4 & 1 & 4 & & 86 & $\begin{array}{l}2 \\
8\end{array}$ & 5 & 7 & $\begin{array}{l}1 \\
9 \\
5\end{array}$ & $\begin{array}{l}21 . \\
67\end{array}$ & $\begin{array}{l}1 \\
3\end{array}$ \\
\hline 59 & 1 & 1 & & & 1 & & & & 1 & & & & & & & 1 & 10 & 2 & 0 & 2 & $\begin{array}{l}2 \\
2\end{array}$ & $\begin{array}{l}22 . \\
00\end{array}$ & $\begin{array}{l}1 \\
1\end{array}$ \\
\hline 60 & 2 & 2 & & & 2 & & & & 2 & & & & 1 & & 1 & & 22 & 5 & 1 & 0 & $\begin{array}{l}4 \\
8\end{array}$ & $\begin{array}{l}24 . \\
00\end{array}$ & 5 \\
\hline 61 & 9 & 9 & & & 9 & & & & 9 & & & & 8 & & 1 & & $\begin{array}{l}10 \\
1\end{array}$ & $\begin{array}{l}1 \\
9\end{array}$ & 1 & 5 & $\begin{array}{l}2 \\
2 \\
0\end{array}$ & $\begin{array}{l}24 . \\
44\end{array}$ & 4 \\
\hline $\begin{array}{l}\text { Tota } \\
1\end{array}$ & 134 & $\begin{array}{l}1 \\
3 \\
4\end{array}$ & & & \begin{tabular}{l|}
1 \\
2 \\
6
\end{tabular} & 3 & & 5 & \begin{tabular}{|l|}
1 \\
1 \\
6
\end{tabular} & & 1 & $\begin{array}{l}1 \\
7\end{array}$ & $\begin{array}{l}7 \\
5\end{array}$ & 9 & $\begin{array}{l}4 \\
0\end{array}$ & $\begin{array}{l}1 \\
\mathbf{0}\end{array}$ & $\begin{array}{l}13 \\
51\end{array}$ & $\begin{array}{l}3 \\
3 \\
7\end{array}$ & $\begin{array}{l}5 \\
6\end{array}$ & $\begin{array}{l}1 \\
3 \\
2\end{array}$ & $\begin{array}{l}2 \\
9 \\
8 \\
3\end{array}$ & $\begin{array}{l}22 . \\
26\end{array}$ & \\
\hline
\end{tabular}

*F: Fully met, P: Partly met, N: Did not meet (No), U: Not known (unknown) 
Annex 4:- Suppliers' Performance Scores By Criterion.

\begin{tabular}{|c|c|c|c|c|c|c|c|c|c|c|c|c|c|c|c|c|}
\hline $\begin{array}{l}\text { No. of } \\
\text { criterio } \\
\mathrm{n} \quad(\mathrm{C}- \\
\mathrm{N}) / \\
\text { Serial } \\
\text { no. of } \\
\text { the } \\
\text { supplie } \\
\text { rs }\end{array}$ & $\begin{array}{l}\mathrm{C}- \\
1\end{array}$ & $\begin{array}{l}\text { C- } \\
2\end{array}$ & $\begin{array}{l}\text { C- } \\
3\end{array}$ & $\begin{array}{l}C- \\
4\end{array}$ & C-5 & $\begin{array}{l}\text { C- } \\
6\end{array}$ & $\begin{array}{l}\text { C- } \\
7\end{array}$ & $\begin{array}{l}\text { C- } \\
8\end{array}$ & $\begin{array}{l}\text { C- } \\
9\end{array}$ & $\begin{array}{l}\text { C- } \\
10\end{array}$ & $\begin{array}{l}\text { C- } \\
11\end{array}$ & $\begin{array}{l}\text { C- } \\
12\end{array}$ & $\begin{array}{l}\text { C- } \\
13\end{array}$ & $\begin{array}{l}\text { C- } \\
14\end{array}$ & $\begin{array}{l}\text { Tot } \\
\text { al }\end{array}$ & $\begin{array}{l}\text { Percenta } \\
\text { ge }\end{array}$ \\
\hline S-1 & $\begin{array}{l}1.6 \\
7 \\
\end{array}$ & $\begin{array}{l}1.3 \\
3 \\
\end{array}$ & $\begin{array}{l}1.0 \\
0\end{array}$ & $\begin{array}{l}1.6 \\
7 \\
\end{array}$ & 1.67 & $\begin{array}{l}2 . \\
00\end{array}$ & $\begin{array}{l}1.3 \\
3 \\
\end{array}$ & $\begin{array}{l}1.6 \\
7 \\
\end{array}$ & $\begin{array}{l}2.0 \\
0 \\
\end{array}$ & $\begin{array}{l}1.6 \\
7 \\
\end{array}$ & $\begin{array}{l}2.0 \\
0 \\
\end{array}$ & $\begin{array}{l}2.0 \\
0 \\
\end{array}$ & $\begin{array}{l}2.0 \\
0 \\
\end{array}$ & 1.67 & $\begin{array}{l}23 . \\
67\end{array}$ & $85 \%$ \\
\hline S-2 & $\begin{array}{l}2.0 \\
0 \\
\end{array}$ & $\begin{array}{l}2.0 \\
0\end{array}$ & $\begin{array}{l}1.0 \\
0\end{array}$ & $\begin{array}{l}2.0 \\
0 \\
\end{array}$ & 1.00 & $\begin{array}{l}2 . \\
00\end{array}$ & $\begin{array}{l}2.0 \\
0\end{array}$ & $\begin{array}{l}2.0 \\
0 \\
\end{array}$ & $\begin{array}{l}2.0 \\
0\end{array}$ & $\begin{array}{l}2.0 \\
0 \\
\end{array}$ & $\begin{array}{l}2.0 \\
0 \\
\end{array}$ & $\begin{array}{l}2.0 \\
0 \\
\end{array}$ & $\begin{array}{l}2.0 \\
0\end{array}$ & 2.00 & $\begin{array}{l}26 . \\
00\end{array}$ & $93 \%$ \\
\hline S-3 & $\begin{array}{l}2.0 \\
0 \\
\end{array}$ & $\begin{array}{l}1.0 \\
0\end{array}$ & $\begin{array}{l}1.0 \\
0\end{array}$ & $\begin{array}{l}1.5 \\
0\end{array}$ & 1.00 & $\begin{array}{l}2 . \\
00\end{array}$ & $\begin{array}{l}2.0 \\
0\end{array}$ & $\begin{array}{l}2.0 \\
0\end{array}$ & $\begin{array}{l}2.0 \\
0\end{array}$ & $\begin{array}{l}2.0 \\
0\end{array}$ & $\begin{array}{l}2.0 \\
0\end{array}$ & $\begin{array}{l}2.0 \\
0 \\
\end{array}$ & $\begin{array}{l}2.0 \\
0\end{array}$ & 2.00 & $\begin{array}{l}24 . \\
50\end{array}$ & $88 \%$ \\
\hline S-4 & $\begin{array}{l}2.0 \\
0 \\
\end{array}$ & $\begin{array}{l}0.5 \\
0 \\
\end{array}$ & $\begin{array}{l}1.0 \\
0 \\
\end{array}$ & $\begin{array}{l}2.0 \\
0 \\
\end{array}$ & 1.00 & $\begin{array}{l}2 . \\
00\end{array}$ & $\begin{array}{l}2.0 \\
0 \\
\end{array}$ & $\begin{array}{l}2.0 \\
0 \\
\end{array}$ & $\begin{array}{l}2.0 \\
0 \\
\end{array}$ & $\begin{array}{l}2.0 \\
0 \\
\end{array}$ & $\begin{array}{l}2.0 \\
0 \\
\end{array}$ & $\begin{array}{l}2.0 \\
0 \\
\end{array}$ & $\begin{array}{l}2.0 \\
0 \\
\end{array}$ & 0.50 & $\begin{array}{l}23 . \\
00\end{array}$ & $82 \%$ \\
\hline S-5 & $\begin{array}{l}2.0 \\
0\end{array}$ & $\begin{array}{l}2.0 \\
0\end{array}$ & $\begin{array}{l}2.0 \\
0\end{array}$ & $\begin{array}{l}1.0 \\
0\end{array}$ & 2.00 & $\begin{array}{l}2 . \\
00\end{array}$ & $\begin{array}{l}2.0 \\
0\end{array}$ & $\begin{array}{l}- \\
1.0 \\
0\end{array}$ & $\begin{array}{l}2.0 \\
0\end{array}$ & $\begin{array}{l}2.0 \\
0\end{array}$ & $\begin{array}{l}2.0 \\
0\end{array}$ & $\begin{array}{l}0.0 \\
0\end{array}$ & $\begin{array}{l}2.0 \\
0\end{array}$ & $\begin{array}{l}- \\
1.00\end{array}$ & $\begin{array}{l}19 . \\
00\end{array}$ & $68 \%$ \\
\hline S-6 & $\begin{array}{l}1.7 \\
5\end{array}$ & $\begin{array}{l}1.0 \\
0\end{array}$ & $\begin{array}{l}1.5 \\
0\end{array}$ & $\begin{array}{l}1.2 \\
5\end{array}$ & 1.00 & $\begin{array}{l}1 . \\
50\end{array}$ & $\begin{array}{l}2.0 \\
0\end{array}$ & $\begin{array}{l}1.0 \\
0\end{array}$ & $\begin{array}{l}1.5 \\
0\end{array}$ & $\begin{array}{l}2.0 \\
0\end{array}$ & $\begin{array}{l}2.0 \\
0\end{array}$ & $\begin{array}{l}1.5 \\
0\end{array}$ & $\begin{array}{l}1.5 \\
0\end{array}$ & $\overline{0} .25$ & $\begin{array}{l}19 . \\
25\end{array}$ & $69 \%$ \\
\hline S-7 & $\begin{array}{l}2.0 \\
0\end{array}$ & $\begin{array}{l}2.0 \\
0\end{array}$ & $\begin{array}{l}1.0 \\
0\end{array}$ & $\begin{array}{l}2.0 \\
0\end{array}$ & 1.00 & $\begin{array}{l}2 . \\
00\end{array}$ & $\begin{array}{l}2.0 \\
0\end{array}$ & $\begin{array}{l}2.0 \\
0\end{array}$ & $\begin{array}{l}2.0 \\
0\end{array}$ & $\begin{array}{l}2.0 \\
0\end{array}$ & $\begin{array}{l}2.0 \\
0\end{array}$ & $\begin{array}{l}2.0 \\
0\end{array}$ & $\begin{array}{l}2.0 \\
0\end{array}$ & 2.00 & $\begin{array}{l}26 . \\
00\end{array}$ & $93 \%$ \\
\hline S-8 & $\begin{array}{l}2.0 \\
0 \\
\end{array}$ & $\begin{array}{l}1.0 \\
0\end{array}$ & $\begin{array}{l}1.0 \\
0\end{array}$ & $\begin{array}{l}1.5 \\
0\end{array}$ & 1.00 & $\begin{array}{l}2 . \\
00\end{array}$ & $\begin{array}{l}2.0 \\
0\end{array}$ & $\begin{array}{l}2.0 \\
0 \\
\end{array}$ & $\begin{array}{l}2.0 \\
0\end{array}$ & $\begin{array}{l}2.0 \\
0 \\
\end{array}$ & $\begin{array}{l}2.0 \\
0\end{array}$ & $\begin{array}{l}2.0 \\
0 \\
\end{array}$ & $\begin{array}{l}2.0 \\
0\end{array}$ & 2.00 & $\begin{array}{l}24 . \\
50\end{array}$ & $88 \%$ \\
\hline S-9 & $\begin{array}{l}1.7 \\
5\end{array}$ & $\begin{array}{l}1.0 \\
0 \\
\end{array}$ & $\begin{array}{l}1.0 \\
0 \\
\end{array}$ & $\begin{array}{l}2.0 \\
0 \\
\end{array}$ & 1.50 & $\begin{array}{l}1 . \\
50\end{array}$ & $\begin{array}{l}2.0 \\
0 \\
\end{array}$ & $\begin{array}{l}2.0 \\
0\end{array}$ & $\begin{array}{l}2.0 \\
0 \\
\end{array}$ & $\begin{array}{l}1.5 \\
0\end{array}$ & $\begin{array}{l}2.0 \\
0 \\
\end{array}$ & $\begin{array}{l}1.5 \\
0\end{array}$ & $\begin{array}{l}1.0 \\
0 \\
\end{array}$ & 1.25 & $\begin{array}{l}22 . \\
00\end{array}$ & $79 \%$ \\
\hline S-10 & $\begin{array}{l}1.3 \\
3 \\
\end{array}$ & $\begin{array}{l}1.3 \\
3 \\
\end{array}$ & $\begin{array}{l}1.3 \\
3 \\
\end{array}$ & $\begin{array}{l}1.6 \\
7 \\
\end{array}$ & 1.00 & $\begin{array}{l}1 . \\
33\end{array}$ & $\begin{array}{l}1.3 \\
3 \\
\end{array}$ & $\begin{array}{l}2.0 \\
0 \\
\end{array}$ & $\begin{array}{l}2.0 \\
0 \\
\end{array}$ & $\begin{array}{l}2.0 \\
0 \\
\end{array}$ & $\begin{array}{l}2.0 \\
0 \\
\end{array}$ & $\begin{array}{l}2.0 \\
0 \\
\end{array}$ & $\begin{array}{l}1.3 \\
3 \\
\end{array}$ & 2.00 & $\begin{array}{l}22 . \\
67 \\
\end{array}$ & $81 \%$ \\
\hline S-11 & $\begin{array}{l}1.5 \\
0 \\
\end{array}$ & $\begin{array}{l}0.0 \\
0 \\
\end{array}$ & $\begin{array}{l}1.0 \\
0 \\
\end{array}$ & $\begin{array}{l}1.5 \\
0 \\
\end{array}$ & 1.00 & $\begin{array}{l}2 . \\
00 \\
\end{array}$ & $\begin{array}{l}2.0 \\
0 \\
\end{array}$ & $\begin{array}{l}2.0 \\
0 \\
\end{array}$ & $\begin{array}{l}2.0 \\
0 \\
\end{array}$ & $\begin{array}{l}2.0 \\
0 \\
\end{array}$ & $\begin{array}{l}2.0 \\
0 \\
\end{array}$ & $\begin{array}{l}2.0 \\
0 \\
\end{array}$ & $\begin{array}{l}2.0 \\
0 \\
\end{array}$ & 0.50 & $\begin{array}{l}21 . \\
50\end{array}$ & $77 \%$ \\
\hline S-12 & $\begin{array}{l}2.0 \\
0 \\
\end{array}$ & $\begin{array}{l}0.0 \\
0 \\
\end{array}$ & $\begin{array}{l}1.0 \\
0\end{array}$ & $\begin{array}{l}1.0 \\
0 \\
\end{array}$ & 1.00 & $\begin{array}{l}2 . \\
00\end{array}$ & $\begin{array}{l}2.0 \\
0 \\
\end{array}$ & $\begin{array}{l}2.0 \\
0 \\
\end{array}$ & $\begin{array}{l}2.0 \\
0 \\
\end{array}$ & $\begin{array}{l}2.0 \\
0 \\
\end{array}$ & $\begin{array}{l}2.0 \\
0 \\
\end{array}$ & $\begin{array}{l}2.0 \\
0 \\
\end{array}$ & $\begin{array}{l}2.0 \\
0 \\
\end{array}$ & 2.00 & $\begin{array}{l}23 . \\
00\end{array}$ & $82 \%$ \\
\hline S-13 & $\begin{array}{l}2.0 \\
0 \\
\end{array}$ & $\begin{array}{l}0.0 \\
0 \\
\end{array}$ & $\begin{array}{l}1.0 \\
0\end{array}$ & $\begin{array}{l}1.0 \\
0 \\
\end{array}$ & 2.00 & $\begin{array}{l}0 . \\
00\end{array}$ & $\begin{array}{l}2.0 \\
0 \\
\end{array}$ & $\begin{array}{l}2.0 \\
0 \\
\end{array}$ & $\begin{array}{l}2.0 \\
0 \\
\end{array}$ & $\begin{array}{l}2.0 \\
0 \\
\end{array}$ & $\begin{array}{l}2.0 \\
0 \\
\end{array}$ & $\begin{array}{l}0.0 \\
0 \\
\end{array}$ & $\begin{array}{l}0.0 \\
0\end{array}$ & $\overline{-}$ & $\begin{array}{l}15 . \\
00\end{array}$ & $54 \%$ \\
\hline S-14 & $\begin{array}{l}2.0 \\
0\end{array}$ & $\begin{array}{l}2.0 \\
0\end{array}$ & $\begin{array}{l}1.0 \\
0\end{array}$ & $\begin{array}{l}2.0 \\
0\end{array}$ & 1.00 & $\begin{array}{l}0 . \\
00\end{array}$ & $\begin{array}{l}2.0 \\
0\end{array}$ & $\begin{array}{l}2.0 \\
0\end{array}$ & $\begin{array}{l}2.0 \\
0\end{array}$ & $\begin{array}{l}2.0 \\
0\end{array}$ & $\begin{array}{l}2.0 \\
0\end{array}$ & $\begin{array}{l}2.0 \\
0\end{array}$ & $\begin{array}{l}2.0 \\
0 \\
\end{array}$ & $-\overline{1.00}$ & $\begin{array}{l}21 . \\
00\end{array}$ & $75 \%$ \\
\hline S-15 & $\begin{array}{l}2.0 \\
0 \\
\end{array}$ & $\begin{array}{l}0.6 \\
7\end{array}$ & $\begin{array}{l}1.3 \\
3\end{array}$ & $\begin{array}{l}1.3 \\
3 \\
\end{array}$ & 0.33 & $\begin{array}{l}1 . \\
33\end{array}$ & $\begin{array}{l}2.0 \\
0 \\
\end{array}$ & $\begin{array}{l}1.3 \\
3 \\
\end{array}$ & $\begin{array}{l}1.3 \\
3\end{array}$ & $\begin{array}{l}2.0 \\
0 \\
\end{array}$ & $\begin{array}{l}2.0 \\
0 \\
\end{array}$ & $\begin{array}{l}2.0 \\
0 \\
\end{array}$ & $\begin{array}{l}1.3 \\
3\end{array}$ & 1.33 & $\begin{array}{l}20 . \\
33\end{array}$ & $73 \%$ \\
\hline S-16 & $\begin{array}{l}2.0 \\
0\end{array}$ & $\begin{array}{l}2.0 \\
0\end{array}$ & $\begin{array}{l}1.0 \\
0\end{array}$ & $\begin{array}{l}2.0 \\
0\end{array}$ & 2.00 & $\begin{array}{l}2 . \\
00\end{array}$ & $\begin{array}{l}2.0 \\
0\end{array}$ & $\begin{array}{l}2.0 \\
0\end{array}$ & $\begin{array}{l}2.0 \\
0\end{array}$ & $\begin{array}{l}2.0 \\
0\end{array}$ & $\begin{array}{l}2.0 \\
0\end{array}$ & $\begin{array}{l}2.0 \\
0\end{array}$ & $\begin{array}{l}2.0 \\
0 \\
\end{array}$ & 2.00 & $\begin{array}{l}27 . \\
00\end{array}$ & $96 \%$ \\
\hline S-17 & $\begin{array}{l}2.0 \\
0 \\
\end{array}$ & $\begin{array}{l}0.0 \\
0 \\
\end{array}$ & $\begin{array}{l}1.0 \\
0\end{array}$ & $\begin{array}{l}2.0 \\
0 \\
\end{array}$ & 1.00 & $\begin{array}{l}2 . \\
00\end{array}$ & $\begin{array}{l}2.0 \\
0 \\
\end{array}$ & $\begin{array}{l}2.0 \\
0 \\
\end{array}$ & $\begin{array}{l}2.0 \\
0 \\
\end{array}$ & $\begin{array}{l}2.0 \\
0 \\
\end{array}$ & $\begin{array}{l}2.0 \\
0 \\
\end{array}$ & $\begin{array}{l}2.0 \\
0 \\
\end{array}$ & $\begin{array}{l}2.0 \\
0 \\
\end{array}$ & $\overline{1}-\overline{1.00}$ & $\begin{array}{l}21 . \\
00\end{array}$ & $75 \%$ \\
\hline S-18 & $\begin{array}{l}2.0 \\
0 \\
\end{array}$ & $\begin{array}{l}2.0 \\
0 \\
\end{array}$ & $\begin{array}{l}1.0 \\
0 \\
\end{array}$ & $\begin{array}{l}2.0 \\
0 \\
\end{array}$ & 1.00 & $\begin{array}{l}2 . \\
00 \\
\end{array}$ & $\begin{array}{l}2.0 \\
0 \\
\end{array}$ & $\begin{array}{l}2.0 \\
0 \\
\end{array}$ & $\begin{array}{l}2.0 \\
0 \\
\end{array}$ & $\begin{array}{l}2.0 \\
0 \\
\end{array}$ & $\begin{array}{l}2.0 \\
0 \\
\end{array}$ & $\begin{array}{l}2.0 \\
0 \\
\end{array}$ & $\begin{array}{l}2.0 \\
0 \\
\end{array}$ & 2.00 & $\begin{array}{l}26 . \\
00\end{array}$ & $93 \%$ \\
\hline S-19 & $\begin{array}{l}1.5 \\
0 \\
\end{array}$ & $\begin{array}{l}1.0 \\
0 \\
\end{array}$ & $\begin{array}{l}1.0 \\
0 \\
\end{array}$ & $\begin{array}{l}1.5 \\
0 \\
\end{array}$ & 1.50 & $\begin{array}{l}2 . \\
00\end{array}$ & $\begin{array}{l}1.0 \\
0 \\
\end{array}$ & $\begin{array}{l}1.5 \\
0 \\
\end{array}$ & $\begin{array}{l}2.0 \\
0 \\
\end{array}$ & $\begin{array}{l}1.5 \\
0 \\
\end{array}$ & $\begin{array}{l}2.0 \\
0 \\
\end{array}$ & $\begin{array}{l}2.0 \\
0 \\
\end{array}$ & $\begin{array}{l}2.0 \\
0 \\
\end{array}$ & 1.50 & $\begin{array}{l}22 . \\
00\end{array}$ & $79 \%$ \\
\hline S-20 & $\begin{array}{l}2.0 \\
0\end{array}$ & $\begin{array}{l}0.0 \\
0\end{array}$ & $\begin{array}{l}1.0 \\
0\end{array}$ & $\begin{array}{l}1.0 \\
0\end{array}$ & 1.00 & $\begin{array}{l}2 . \\
00\end{array}$ & $\begin{array}{l}2.0 \\
0\end{array}$ & $\begin{array}{l}2.0 \\
0\end{array}$ & $\begin{array}{l}2.0 \\
0\end{array}$ & $\begin{array}{l}2.0 \\
0\end{array}$ & $\begin{array}{l}2.0 \\
0\end{array}$ & $\begin{array}{l}2.0 \\
0\end{array}$ & $\begin{array}{l}2.0 \\
0 \\
\end{array}$ & 2.00 & $\begin{array}{l}23 . \\
00\end{array}$ & $82 \%$ \\
\hline S-21 & $\begin{array}{l}1.0 \\
0\end{array}$ & $\begin{array}{l}1.0 \\
0\end{array}$ & $\begin{array}{l}1.5 \\
0\end{array}$ & $\begin{array}{l}1.5 \\
0\end{array}$ & 1.00 & $\begin{array}{l}2 . \\
00\end{array}$ & $\begin{array}{l}2.0 \\
0\end{array}$ & $\begin{array}{l}2.0 \\
0\end{array}$ & $\begin{array}{l}2.0 \\
0\end{array}$ & $\begin{array}{l}2.0 \\
0\end{array}$ & $\begin{array}{l}2.0 \\
0\end{array}$ & $\begin{array}{l}2.0 \\
0\end{array}$ & $\begin{array}{l}1.0 \\
0\end{array}$ & $\overline{-}-50$ & $\begin{array}{l}20 . \\
50\end{array}$ & $73 \%$ \\
\hline S-22 & $\begin{array}{l}2.0 \\
0 \\
\end{array}$ & $\begin{array}{l}1.0 \\
0\end{array}$ & $\begin{array}{l}2.0 \\
0\end{array}$ & $\begin{array}{l}1.0 \\
0\end{array}$ & 0.00 & $\begin{array}{l}1 . \\
00\end{array}$ & $\begin{array}{l}2.0 \\
0\end{array}$ & $\begin{array}{l}1.0 \\
0\end{array}$ & $\begin{array}{l}1.0 \\
0 \\
\end{array}$ & $\begin{array}{l}2.0 \\
0\end{array}$ & $\begin{array}{l}2.0 \\
0\end{array}$ & $\begin{array}{l}2.0 \\
0 \\
\end{array}$ & $\begin{array}{l}1.0 \\
0\end{array}$ & $\begin{array}{l}- \\
0.50\end{array}$ & $\begin{array}{l}17 . \\
50\end{array}$ & $63 \%$ \\
\hline
\end{tabular}




\begin{tabular}{|c|c|c|c|c|c|c|c|c|c|c|c|c|c|c|c|c|}
\hline S-23 & $\begin{array}{l}1.3 \\
3\end{array}$ & $\begin{array}{l}1.3 \\
3\end{array}$ & $\begin{array}{l}1.0 \\
0\end{array}$ & $\begin{array}{l}2.0 \\
0\end{array}$ & 1.00 & $\begin{array}{l}2 . \\
00\end{array}$ & $\begin{array}{l}2.0 \\
0\end{array}$ & $\begin{array}{l}2.0 \\
0\end{array}$ & $\begin{array}{l}2.0 \\
0\end{array}$ & $\begin{array}{l}2.0 \\
0\end{array}$ & $\begin{array}{l}2.0 \\
0\end{array}$ & $\begin{array}{l}2.0 \\
0\end{array}$ & $\begin{array}{l}1.3 \\
3\end{array}$ & 0.33 & $\begin{array}{l}22 . \\
33\end{array}$ & $80 \%$ \\
\hline S-24 & $\begin{array}{l}1.5 \\
0\end{array}$ & $\begin{array}{l}2.0 \\
0\end{array}$ & $\begin{array}{l}1.0 \\
0\end{array}$ & $\begin{array}{l}2.0 \\
0\end{array}$ & 1.00 & $\begin{array}{l}2 . \\
00\end{array}$ & $\begin{array}{l}1.0 \\
0\end{array}$ & $\begin{array}{l}1.5 \\
0\end{array}$ & $\begin{array}{l}2.0 \\
0\end{array}$ & $\begin{array}{l}1.5 \\
0\end{array}$ & $\begin{array}{l}2.0 \\
0\end{array}$ & $\begin{array}{l}2.0 \\
0\end{array}$ & $\begin{array}{l}2.0 \\
0\end{array}$ & 1.50 & $\begin{array}{l}23 . \\
00\end{array}$ & $82 \%$ \\
\hline S-25 & $\begin{array}{l}1.5 \\
0\end{array}$ & $\begin{array}{l}0.8 \\
8\end{array}$ & $\begin{array}{l}1.0 \\
0\end{array}$ & $\begin{array}{l}1.6 \\
3\end{array}$ & 0.88 & $\begin{array}{l}1 . \\
75\end{array}$ & $\begin{array}{l}2.0 \\
0\end{array}$ & $\begin{array}{l}2.0 \\
0\end{array}$ & $\begin{array}{l}2.0 \\
0\end{array}$ & $\begin{array}{l}1.7 \\
5\end{array}$ & $\begin{array}{l}2.0 \\
0\end{array}$ & $\begin{array}{l}1.8 \\
8\end{array}$ & $\begin{array}{l}1.5 \\
0\end{array}$ & 0.00 & $\begin{array}{l}20 . \\
75\end{array}$ & $74 \%$ \\
\hline S-26 & $\begin{array}{l}1.0 \\
0\end{array}$ & $\begin{array}{l}0.0 \\
0\end{array}$ & $\begin{array}{l}1.0 \\
0\end{array}$ & $\begin{array}{l}2.0 \\
0\end{array}$ & 2.00 & $\begin{array}{l}2 . \\
00\end{array}$ & $\begin{array}{l}0.0 \\
0\end{array}$ & $\begin{array}{l}1.0 \\
0\end{array}$ & $\begin{array}{l}2.0 \\
0\end{array}$ & $\begin{array}{l}1.0 \\
0\end{array}$ & $\begin{array}{l}2.0 \\
0\end{array}$ & $\begin{array}{l}2.0 \\
0\end{array}$ & $\begin{array}{l}2.0 \\
0\end{array}$ & 2.00 & $\begin{array}{l}20 . \\
00\end{array}$ & $71 \%$ \\
\hline S-27 & $\begin{array}{l}2.0 \\
0\end{array}$ & $\begin{array}{l}2.0 \\
0\end{array}$ & $\begin{array}{l}1.0 \\
0\end{array}$ & $\begin{array}{l}2.0 \\
0\end{array}$ & 1.00 & $\begin{array}{l}2 . \\
00\end{array}$ & $\begin{array}{l}2.0 \\
0\end{array}$ & $\begin{array}{l}2.0 \\
0\end{array}$ & $\begin{array}{l}2.0 \\
0\end{array}$ & $\begin{array}{l}2.0 \\
0\end{array}$ & $\begin{array}{l}2.0 \\
0\end{array}$ & $\begin{array}{l}2.0 \\
0\end{array}$ & $\begin{array}{l}2.0 \\
0\end{array}$ & 2.00 & $\begin{array}{l}26 . \\
00\end{array}$ & $93 \%$ \\
\hline S-28 & $\begin{array}{l}2.0 \\
0\end{array}$ & $\begin{array}{l}1.0 \\
0\end{array}$ & $\begin{array}{l}1.0 \\
0\end{array}$ & $\begin{array}{l}1.5 \\
0\end{array}$ & 1.00 & $\begin{array}{l}2 . \\
00\end{array}$ & $\begin{array}{l}2.0 \\
0\end{array}$ & $\begin{array}{l}2.0 \\
0\end{array}$ & $\begin{array}{l}2.0 \\
0\end{array}$ & $\begin{array}{l}2.0 \\
0\end{array}$ & $\begin{array}{l}2.0 \\
0\end{array}$ & $\begin{array}{l}2.0 \\
0\end{array}$ & $\begin{array}{l}2.0 \\
0\end{array}$ & 2.00 & $\begin{array}{l}24 . \\
50\end{array}$ & $88 \%$ \\
\hline S-29 & $\begin{array}{l}2.0 \\
0\end{array}$ & $\begin{array}{l}0.0 \\
0\end{array}$ & $\begin{array}{l}1.0 \\
0\end{array}$ & $\begin{array}{l}1.0 \\
0\end{array}$ & 1.00 & $\begin{array}{l}2 . \\
00\end{array}$ & $\begin{array}{l}2.0 \\
0\end{array}$ & $\begin{array}{l}2.0 \\
0\end{array}$ & $\begin{array}{l}2.0 \\
0\end{array}$ & $\begin{array}{l}2.0 \\
0\end{array}$ & $\begin{array}{l}2.0 \\
0\end{array}$ & $\begin{array}{l}2.0 \\
0\end{array}$ & $\begin{array}{l}2.0 \\
0\end{array}$ & 2.00 & $\begin{array}{l}23 . \\
00\end{array}$ & $82 \%$ \\
\hline S-30 & $\begin{array}{l}2.0 \\
0\end{array}$ & $\begin{array}{l}0.0 \\
0\end{array}$ & $\begin{array}{l}1.0 \\
0\end{array}$ & $\begin{array}{l}1.0 \\
0\end{array}$ & 1.00 & $\begin{array}{l}2 . \\
00\end{array}$ & $\begin{array}{l}2.0 \\
0\end{array}$ & $\begin{array}{l}2.0 \\
0\end{array}$ & $\begin{array}{l}2.0 \\
0\end{array}$ & $\begin{array}{l}2.0 \\
0\end{array}$ & $\begin{array}{l}2.0 \\
0\end{array}$ & $\begin{array}{l}2.0 \\
0\end{array}$ & $\begin{array}{l}2.0 \\
0\end{array}$ & 2.00 & $\begin{array}{l}23 . \\
00\end{array}$ & $82 \%$ \\
\hline S-31 & $\begin{array}{l}1.0 \\
0 \\
\end{array}$ & $\begin{array}{l}0.0 \\
0 \\
\end{array}$ & $\begin{array}{l}2.0 \\
0 \\
\end{array}$ & $\begin{array}{l}1.0 \\
0 \\
\end{array}$ & 1.00 & $\begin{array}{l}2 . \\
00\end{array}$ & $\begin{array}{l}2.0 \\
0 \\
\end{array}$ & $\begin{array}{l}2.0 \\
0 \\
\end{array}$ & $\begin{array}{l}2.0 \\
0 \\
\end{array}$ & $\begin{array}{l}2.0 \\
0 \\
\end{array}$ & $\begin{array}{l}2.0 \\
0 \\
\end{array}$ & $\begin{array}{l}2.0 \\
0 \\
\end{array}$ & $\begin{array}{l}0.0 \\
0 \\
\end{array}$ & 0.00 & $\begin{array}{l}19 . \\
00\end{array}$ & $68 \%$ \\
\hline S-32 & $\begin{array}{l}2.0 \\
0\end{array}$ & $\begin{array}{l}2.0 \\
0\end{array}$ & $\begin{array}{l}2.0 \\
0\end{array}$ & $\begin{array}{l}0.0 \\
0\end{array}$ & 1.00 & $\begin{array}{l}2 . \\
00\end{array}$ & $\begin{array}{l}2.0 \\
0\end{array}$ & $\begin{array}{l}2.0 \\
0\end{array}$ & $\begin{array}{l}2.0 \\
0\end{array}$ & $\begin{array}{l}2.0 \\
0\end{array}$ & $\begin{array}{l}2.0 \\
0\end{array}$ & $\begin{array}{l}2.0 \\
0\end{array}$ & $\begin{array}{l}2.0 \\
0\end{array}$ & 2.00 & $\begin{array}{l}25 . \\
00\end{array}$ & $89 \%$ \\
\hline S-33 & $\begin{array}{l}1.0 \\
0\end{array}$ & $\begin{array}{l}0.0 \\
0\end{array}$ & $\begin{array}{l}1.0 \\
0\end{array}$ & $\begin{array}{l}2.0 \\
0\end{array}$ & 1.00 & $\begin{array}{l}2 . \\
00\end{array}$ & $\begin{array}{l}2.0 \\
0\end{array}$ & $\begin{array}{l}2.0 \\
0\end{array}$ & $\begin{array}{l}2.0 \\
0\end{array}$ & $\begin{array}{l}2.0 \\
0\end{array}$ & $\begin{array}{l}2.0 \\
0\end{array}$ & $\begin{array}{l}2.0 \\
0\end{array}$ & $\begin{array}{l}2.0 \\
0\end{array}$ & $\begin{array}{l}- \\
1.00\end{array}$ & $\begin{array}{l}20 . \\
00\end{array}$ & $71 \%$ \\
\hline S-34 & $\begin{array}{l}1.0 \\
0\end{array}$ & $\begin{array}{l}0.0 \\
0\end{array}$ & $\begin{array}{l}1.0 \\
0\end{array}$ & $\begin{array}{l}1.0 \\
0\end{array}$ & 1.00 & $\begin{array}{l}2 . \\
00\end{array}$ & $\begin{array}{l}2.0 \\
0\end{array}$ & $\begin{array}{l}2.0 \\
0\end{array}$ & $\begin{array}{l}2.0 \\
0\end{array}$ & $\begin{array}{l}2.0 \\
0\end{array}$ & $\begin{array}{l}2.0 \\
0\end{array}$ & $\begin{array}{l}2.0 \\
0\end{array}$ & $\begin{array}{l}2.0 \\
0\end{array}$ & 2.00 & $\begin{array}{l}22 . \\
00\end{array}$ & $79 \%$ \\
\hline S-35 & $\begin{array}{l}1.5 \\
0\end{array}$ & $\begin{array}{l}2.0 \\
0\end{array}$ & $\begin{array}{l}1.5 \\
0\end{array}$ & $\begin{array}{l}2.0 \\
0\end{array}$ & 1.50 & $\begin{array}{l}2 . \\
00\end{array}$ & $\begin{array}{l}2.0 \\
0\end{array}$ & $\begin{array}{l}2.0 \\
0\end{array}$ & $\begin{array}{l}2.0 \\
0\end{array}$ & $\begin{array}{l}2.0 \\
0\end{array}$ & $\begin{array}{l}2.0 \\
0\end{array}$ & $\begin{array}{l}2.0 \\
0\end{array}$ & $\begin{array}{l}2.0 \\
0\end{array}$ & 0.50 & $\begin{array}{l}25 . \\
00\end{array}$ & $89 \%$ \\
\hline S-36 & $\begin{array}{l}1.6 \\
7\end{array}$ & $\begin{array}{l}1.3 \\
3\end{array}$ & $\begin{array}{l}1.0 \\
0\end{array}$ & $\begin{array}{l}1.6 \\
7\end{array}$ & 1.67 & $\begin{array}{l}2 . \\
00\end{array}$ & $\begin{array}{l}1.3 \\
3\end{array}$ & $\begin{array}{l}1.6 \\
7\end{array}$ & $\begin{array}{l}2.0 \\
0\end{array}$ & $\begin{array}{l}1.6 \\
7\end{array}$ & $\begin{array}{l}2.0 \\
0\end{array}$ & $\begin{array}{l}2.0 \\
0\end{array}$ & $\begin{array}{l}2.0 \\
0\end{array}$ & 1.67 & $\begin{array}{l}23 . \\
67\end{array}$ & $85 \%$ \\
\hline S-37 & $\begin{array}{l}2.0 \\
0\end{array}$ & $\begin{array}{l}0.0 \\
0\end{array}$ & $\begin{array}{l}1.0 \\
0\end{array}$ & $\begin{array}{l}1.0 \\
0\end{array}$ & 1.00 & $\begin{array}{l}2 . \\
00\end{array}$ & $\begin{array}{l}2.0 \\
0\end{array}$ & $\begin{array}{l}2.0 \\
0\end{array}$ & $\begin{array}{l}2.0 \\
0\end{array}$ & $\begin{array}{l}2.0 \\
0\end{array}$ & $\begin{array}{l}2.0 \\
0\end{array}$ & $\begin{array}{l}2.0 \\
0\end{array}$ & $\begin{array}{l}2.0 \\
0\end{array}$ & 2.00 & $\begin{array}{l}23 . \\
00\end{array}$ & $82 \%$ \\
\hline S-38 & $\begin{array}{l}1.5 \\
0\end{array}$ & $\begin{array}{l}2.0 \\
0\end{array}$ & $\begin{array}{l}1.0 \\
0\end{array}$ & $\begin{array}{l}2.0 \\
0 \\
\end{array}$ & 1.00 & $\begin{array}{l}2 . \\
00\end{array}$ & $\begin{array}{l}2.0 \\
0\end{array}$ & $\begin{array}{l}2.0 \\
0 \\
\end{array}$ & $\begin{array}{l}2.0 \\
0 \\
\end{array}$ & $\begin{array}{l}2.0 \\
0\end{array}$ & $\begin{array}{l}2.0 \\
0 \\
\end{array}$ & $\begin{array}{l}2.0 \\
0\end{array}$ & $\begin{array}{l}2.0 \\
0\end{array}$ & 0.50 & $\begin{array}{l}24 . \\
00\end{array}$ & $86 \%$ \\
\hline S-39 & $\begin{array}{l}1.5 \\
0\end{array}$ & $\begin{array}{l}0.0 \\
0\end{array}$ & $\begin{array}{l}1.5 \\
0\end{array}$ & $\begin{array}{l}0.5 \\
0\end{array}$ & 0.50 & $\begin{array}{l}1 . \\
00\end{array}$ & $\begin{array}{l}1.0 \\
0\end{array}$ & $\begin{array}{l}2.0 \\
0\end{array}$ & $\begin{array}{l}2.0 \\
0\end{array}$ & $\begin{array}{l}2.0 \\
0\end{array}$ & $\begin{array}{l}2.0 \\
0\end{array}$ & $\begin{array}{l}1.5 \\
0\end{array}$ & $\begin{array}{l}1.0 \\
0\end{array}$ & $\overline{0}-50$ & $\begin{array}{l}16 . \\
00\end{array}$ & $57 \%$ \\
\hline S-40 & $\begin{array}{l}1.8 \\
0\end{array}$ & $\begin{array}{l}0.6 \\
0\end{array}$ & $\begin{array}{l}1.0 \\
0\end{array}$ & $\begin{array}{l}1.8 \\
0\end{array}$ & 1.00 & $\begin{array}{l}2 . \\
00\end{array}$ & $\begin{array}{l}2.0 \\
0\end{array}$ & $\begin{array}{l}2.0 \\
0\end{array}$ & $\begin{array}{l}2.0 \\
0\end{array}$ & $\begin{array}{l}2.0 \\
0\end{array}$ & $\begin{array}{l}2.0 \\
0\end{array}$ & $\begin{array}{l}2.0 \\
0\end{array}$ & $\begin{array}{l}2.0 \\
0\end{array}$ & 0.80 & $\begin{array}{l}23 . \\
00\end{array}$ & $82 \%$ \\
\hline S-41 & $\begin{array}{l}2.0 \\
0\end{array}$ & $\begin{array}{l}2.0 \\
0\end{array}$ & $\begin{array}{l}1.5 \\
0\end{array}$ & $\begin{array}{l}2.0 \\
0\end{array}$ & 1.50 & $\begin{array}{l}2 . \\
00\end{array}$ & $\begin{array}{l}2.0 \\
0\end{array}$ & $\begin{array}{l}2.0 \\
0\end{array}$ & $\begin{array}{l}2.0 \\
0\end{array}$ & $\begin{array}{l}2.0 \\
0\end{array}$ & $\begin{array}{l}2.0 \\
0\end{array}$ & $\begin{array}{l}2.0 \\
0\end{array}$ & $\begin{array}{l}2.0 \\
0\end{array}$ & 2.00 & $\begin{array}{l}27 . \\
00\end{array}$ & $96 \%$ \\
\hline S-42 & $\begin{array}{l}1.5 \\
0\end{array}$ & $\begin{array}{l}1.0 \\
0\end{array}$ & $\begin{array}{l}1.0 \\
0\end{array}$ & $\begin{array}{l}1.0 \\
0\end{array}$ & 1.00 & $\begin{array}{l}. \\
00\end{array}$ & $\begin{array}{l}1.0 \\
0\end{array}$ & $\begin{array}{l}2.0 \\
0\end{array}$ & $\begin{array}{l}2.0 \\
0\end{array}$ & $\begin{array}{l}2.0 \\
0\end{array}$ & $\begin{array}{l}2.0 \\
0\end{array}$ & $\begin{array}{l}2.0 \\
0\end{array}$ & $\begin{array}{l}1.0 \\
0\end{array}$ & 2.00 & $\begin{array}{l}20 . \\
50\end{array}$ & $73 \%$ \\
\hline S-43 & $\begin{array}{l}2.0 \\
0 \\
\end{array}$ & $\begin{array}{l}0.0 \\
0\end{array}$ & $\begin{array}{l}2.0 \\
0\end{array}$ & $\begin{array}{l}0.0 \\
0\end{array}$ & $\begin{array}{l}- \\
1.00\end{array}$ & $\begin{array}{l}0 . \\
00\end{array}$ & $\begin{array}{l}2.0 \\
0\end{array}$ & $\begin{array}{l}0.0 \\
0\end{array}$ & $\begin{array}{l}0.0 \\
0\end{array}$ & $\begin{array}{l}2.0 \\
0\end{array}$ & $\begin{array}{l}2.0 \\
0\end{array}$ & $\begin{array}{l}2.0 \\
0\end{array}$ & $\begin{array}{l}0.0 \\
0\end{array}$ & 0.00 & $\begin{array}{l}11 . \\
00\end{array}$ & $39 \%$ \\
\hline S-44 & $\begin{array}{l}2.0 \\
0\end{array}$ & $\begin{array}{l}2.0 \\
0\end{array}$ & $\begin{array}{l}1.0 \\
0\end{array}$ & $\begin{array}{l}2.0 \\
0\end{array}$ & 1.00 & $\begin{array}{l}2 . \\
00\end{array}$ & $\begin{array}{l}2.0 \\
0\end{array}$ & $\begin{array}{l}2.0 \\
0\end{array}$ & $\begin{array}{l}2.0 \\
0\end{array}$ & $\begin{array}{l}2.0 \\
0\end{array}$ & $\begin{array}{l}2.0 \\
0\end{array}$ & $\begin{array}{l}2.0 \\
0\end{array}$ & $\begin{array}{l}2.0 \\
0\end{array}$ & 2.00 & $\begin{array}{l}26 . \\
00\end{array}$ & $93 \%$ \\
\hline S-45 & $\begin{array}{l}2.0 \\
0\end{array}$ & $\begin{array}{l}0.0 \\
0\end{array}$ & $\begin{array}{l}1.0 \\
0\end{array}$ & $\begin{array}{l}1.0 \\
0\end{array}$ & 1.50 & $\begin{array}{l}1 . \\
00\end{array}$ & $\begin{array}{l}1.0 \\
0\end{array}$ & $\begin{array}{l}1.5 \\
0\end{array}$ & $\begin{array}{l}2.0 \\
0\end{array}$ & $\begin{array}{l}2.0 \\
0\end{array}$ & $\begin{array}{l}2.0 \\
0\end{array}$ & $\begin{array}{l}1.5 \\
0\end{array}$ & $\begin{array}{l}0.5 \\
0\end{array}$ & 0.50 & $\begin{array}{l}17 . \\
50\end{array}$ & $63 \%$ \\
\hline S-46 & $\begin{array}{l}2.0 \\
0\end{array}$ & $\begin{array}{l}0.0 \\
0\end{array}$ & $\begin{array}{l}1.0 \\
0\end{array}$ & $\begin{array}{l}1.0 \\
0\end{array}$ & 1.00 & $\begin{array}{l}2 . \\
00\end{array}$ & $\begin{array}{l}2.0 \\
0\end{array}$ & $\begin{array}{l}2.0 \\
0\end{array}$ & $\begin{array}{l}2.0 \\
0\end{array}$ & $\begin{array}{l}2.0 \\
0\end{array}$ & $\begin{array}{l}2.0 \\
0\end{array}$ & $\begin{array}{l}2.0 \\
0\end{array}$ & $\begin{array}{l}2.0 \\
0\end{array}$ & 2.00 & $\begin{array}{l}23 . \\
00\end{array}$ & $82 \%$ \\
\hline S-47 & $\begin{array}{l}1.5 \\
0\end{array}$ & $\begin{array}{l}2.0 \\
0\end{array}$ & $\begin{array}{l}1.0 \\
0\end{array}$ & $\begin{array}{l}2.0 \\
0\end{array}$ & 1.00 & $\begin{array}{l}2 . \\
00\end{array}$ & $\begin{array}{l}2.0 \\
0\end{array}$ & $\begin{array}{l}2.0 \\
0\end{array}$ & $\begin{array}{l}2.0 \\
0\end{array}$ & $\begin{array}{l}2.0 \\
0\end{array}$ & $\begin{array}{l}2.0 \\
0\end{array}$ & $\begin{array}{l}2.0 \\
0\end{array}$ & $\begin{array}{l}2.0 \\
0\end{array}$ & 0.50 & $\begin{array}{l}24 . \\
00\end{array}$ & $86 \%$ \\
\hline S-48 & $\begin{array}{l}1.5 \\
0\end{array}$ & $\begin{array}{l}2.0 \\
0\end{array}$ & $\begin{array}{l}1.0 \\
0\end{array}$ & $\begin{array}{l}2.0 \\
0\end{array}$ & 1.00 & $\begin{array}{l}2 . \\
00\end{array}$ & $\begin{array}{l}2.0 \\
0\end{array}$ & $\begin{array}{l}2.0 \\
0\end{array}$ & $\begin{array}{l}2.0 \\
0\end{array}$ & $\begin{array}{l}2.0 \\
0\end{array}$ & $\begin{array}{l}2.0 \\
0\end{array}$ & $\begin{array}{l}2.0 \\
0\end{array}$ & $\begin{array}{l}2.0 \\
0\end{array}$ & 0.50 & $\begin{array}{l}24 . \\
00\end{array}$ & $86 \%$ \\
\hline S-49 & & $\begin{array}{l}2.0 \\
0\end{array}$ & $\begin{array}{l}1.0 \\
0\end{array}$ & $\begin{array}{l}2.0 \\
0\end{array}$ & 1.00 & $\begin{array}{l}2 . \\
00\end{array}$ & $\begin{array}{l}2.0 \\
0\end{array}$ & $\begin{array}{l}2.0 \\
0\end{array}$ & $\begin{array}{l}2.0 \\
0\end{array}$ & $\begin{array}{l}2.0 \\
0\end{array}$ & $\begin{array}{l}2.0 \\
0\end{array}$ & $\begin{array}{l}2.0 \\
0\end{array}$ & $\begin{array}{l}2.0 \\
0\end{array}$ & 0.50 & $\begin{array}{l}24 . \\
00\end{array}$ & $86 \%$ \\
\hline
\end{tabular}




\begin{tabular}{|c|c|c|c|c|c|c|c|c|c|c|c|c|c|c|c|c|}
\hline S-50 & $\begin{array}{l}1.3 \\
3\end{array}$ & $\begin{array}{l}0.3 \\
3\end{array}$ & $\begin{array}{l}1.0 \\
0\end{array}$ & $\begin{array}{l}1.6 \\
7\end{array}$ & 1.33 & $\begin{array}{l}2 . \\
00\end{array}$ & $\begin{array}{l}1.3 \\
3\end{array}$ & $\begin{array}{l}1.6 \\
7\end{array}$ & $\begin{array}{l}2.0 \\
0\end{array}$ & $\begin{array}{l}1.6 \\
7\end{array}$ & $\begin{array}{l}2.0 \\
0\end{array}$ & $\begin{array}{l}2.0 \\
0\end{array}$ & $\begin{array}{l}2.0 \\
0\end{array}$ & 0.67 & $\begin{array}{l}21 . \\
00\end{array}$ & $75 \%$ \\
\hline S-51 & $\begin{array}{l}1.7 \\
5\end{array}$ & $\begin{array}{l}1.5 \\
0\end{array}$ & $\begin{array}{l}1.5 \\
0\end{array}$ & $\begin{array}{l}1.2 \\
5\end{array}$ & 0.75 & $\begin{array}{l}2 . \\
00\end{array}$ & $\begin{array}{l}2.0 \\
0\end{array}$ & $\begin{array}{l}1.2 \\
5\end{array}$ & $\begin{array}{l}2.0 \\
0\end{array}$ & $\begin{array}{l}2.0 \\
0\end{array}$ & $\begin{array}{l}2.0 \\
0\end{array}$ & $\begin{array}{l}1.5 \\
0\end{array}$ & $\begin{array}{l}2.0 \\
0\end{array}$ & 0.25 & $\begin{array}{l}21 . \\
75\end{array}$ & $78 \%$ \\
\hline S-52 & $\begin{array}{l}2.0 \\
0 \\
\end{array}$ & $\begin{array}{l}2.0 \\
0 \\
\end{array}$ & $\begin{array}{l}1.0 \\
0\end{array}$ & $\begin{array}{l}1.0 \\
0\end{array}$ & $-\overline{1.00}$ & $\begin{array}{l}2 . \\
00\end{array}$ & $\begin{array}{l}2.0 \\
0 \\
\end{array}$ & $\begin{array}{l}2.0 \\
0 \\
\end{array}$ & $\begin{array}{l}2.0 \\
0 \\
\end{array}$ & $\begin{array}{l}2.0 \\
0 \\
\end{array}$ & $\begin{array}{l}2.0 \\
0 \\
\end{array}$ & $\begin{array}{l}2.0 \\
0 \\
\end{array}$ & $\begin{array}{l}2.0 \\
0 \\
\end{array}$ & 0.00 & $\begin{array}{l}21 . \\
00\end{array}$ & $75 \%$ \\
\hline S-53 & $\begin{array}{l}1.5 \\
0\end{array}$ & $\begin{array}{l}1.3 \\
3 \\
\end{array}$ & $\begin{array}{l}1.6 \\
7 \\
\end{array}$ & $\begin{array}{l}1.3 \\
3 \\
\end{array}$ & 1.00 & $\begin{array}{l}2 . \\
00\end{array}$ & $\begin{array}{l}2.0 \\
0 \\
\end{array}$ & $\begin{array}{l}2.0 \\
0\end{array}$ & $\begin{array}{l}2.0 \\
0 \\
\end{array}$ & $\begin{array}{l}2.0 \\
0 \\
\end{array}$ & $\begin{array}{l}2.0 \\
0 \\
\end{array}$ & $\begin{array}{l}2.0 \\
0 \\
\end{array}$ & $\begin{array}{l}2.0 \\
0 \\
\end{array}$ & 0.00 & $\begin{array}{l}22 . \\
83\end{array}$ & $82 \%$ \\
\hline S-54 & $\begin{array}{l}1.0 \\
0\end{array}$ & $\begin{array}{l}1.0 \\
0\end{array}$ & $\begin{array}{l}1.0 \\
0\end{array}$ & $\begin{array}{l}1.0 \\
0\end{array}$ & 1.00 & $\begin{array}{l}1 . \\
00\end{array}$ & $\begin{array}{l}1.0 \\
0\end{array}$ & $\begin{array}{l}2.0 \\
0\end{array}$ & $\begin{array}{l}2.0 \\
0\end{array}$ & $\begin{array}{l}2.0 \\
0\end{array}$ & $\begin{array}{l}2.0 \\
0\end{array}$ & $\begin{array}{l}2.0 \\
0\end{array}$ & $\begin{array}{l}1.0 \\
0\end{array}$ & 2.00 & $\begin{array}{l}20 . \\
00\end{array}$ & $71 \%$ \\
\hline S-55 & $\begin{array}{l}2.0 \\
0\end{array}$ & $\begin{array}{l}0.0 \\
0\end{array}$ & $\begin{array}{l}1.0 \\
0\end{array}$ & $\begin{array}{l}1.0 \\
0\end{array}$ & 1.00 & $\begin{array}{l}2 . \\
00\end{array}$ & $\begin{array}{l}2.0 \\
0\end{array}$ & $\begin{array}{l}2.0 \\
0 \\
\end{array}$ & $\begin{array}{l}2.0 \\
0\end{array}$ & $\begin{array}{l}2.0 \\
0\end{array}$ & $\begin{array}{l}2.0 \\
0\end{array}$ & $\begin{array}{l}2.0 \\
0\end{array}$ & $\begin{array}{l}2.0 \\
0\end{array}$ & 2.00 & $\begin{array}{l}23 . \\
00\end{array}$ & $82 \%$ \\
\hline S-56 & $\begin{array}{l}2.0 \\
0\end{array}$ & $\begin{array}{l}0.0 \\
0\end{array}$ & $\begin{array}{l}1.0 \\
0\end{array}$ & $\begin{array}{l}1.0 \\
0\end{array}$ & 1.00 & $\begin{array}{l}2 . \\
00\end{array}$ & $\begin{array}{l}2.0 \\
0\end{array}$ & $\begin{array}{l}2.0 \\
0\end{array}$ & $\begin{array}{l}2.0 \\
0\end{array}$ & $\begin{array}{l}2.0 \\
0\end{array}$ & $\begin{array}{l}2.0 \\
0\end{array}$ & $\begin{array}{l}2.0 \\
0\end{array}$ & $\begin{array}{l}2.0 \\
0\end{array}$ & 2.00 & $\begin{array}{l}23 . \\
00\end{array}$ & $82 \%$ \\
\hline S-57 & $\begin{array}{l}2.0 \\
0\end{array}$ & $\begin{array}{l}2.0 \\
0 \\
\end{array}$ & $\begin{array}{l}1.0 \\
0\end{array}$ & $\begin{array}{l}2.0 \\
0\end{array}$ & 1.00 & $\begin{array}{l}2 . \\
00\end{array}$ & $\begin{array}{l}2.0 \\
0\end{array}$ & $\begin{array}{l}2.0 \\
0\end{array}$ & $\begin{array}{l}2.0 \\
0\end{array}$ & $\begin{array}{l}2.0 \\
0\end{array}$ & $\begin{array}{l}2.0 \\
0\end{array}$ & $\begin{array}{l}2.0 \\
0\end{array}$ & $\begin{array}{l}2.0 \\
0\end{array}$ & 2.00 & $\begin{array}{l}26 . \\
00\end{array}$ & $93 \%$ \\
\hline S-58 & $\begin{array}{l}1.3 \\
3\end{array}$ & $\begin{array}{l}1.0 \\
0\end{array}$ & $\begin{array}{l}1.1 \\
1\end{array}$ & $\begin{array}{l}1.6 \\
7\end{array}$ & 1.11 & $\begin{array}{l}2 . \\
00\end{array}$ & $\begin{array}{l}1.5 \\
6\end{array}$ & $\begin{array}{l}1.8 \\
9\end{array}$ & $\begin{array}{l}2.0 \\
0\end{array}$ & $\begin{array}{l}1.6 \\
7\end{array}$ & $\begin{array}{l}2.0 \\
0\end{array}$ & $\begin{array}{l}2.0 \\
0\end{array}$ & $\begin{array}{l}1.7 \\
8\end{array}$ & 0.56 & $\begin{array}{l}21 . \\
67\end{array}$ & $77 \%$ \\
\hline $\begin{array}{l}S-59 \\
\end{array}$ & $\begin{array}{l}2.0 \\
0\end{array}$ & $\begin{array}{l}0.0 \\
0\end{array}$ & $\begin{array}{l}1.0 \\
0\end{array}$ & $\begin{array}{l}2.0 \\
0\end{array}$ & 1.00 & $\begin{array}{l}2 . \\
00\end{array}$ & $\begin{array}{l}2.0 \\
0\end{array}$ & $\begin{array}{l}2.0 \\
0\end{array}$ & $\begin{array}{l}2.0 \\
0\end{array}$ & $\begin{array}{l}2.0 \\
0\end{array}$ & $\begin{array}{l}2.0 \\
0\end{array}$ & $\begin{array}{l}2.0 \\
0\end{array}$ & $\begin{array}{l}2.0 \\
0 \\
\end{array}$ & 0.00 & $\begin{array}{l}22 . \\
00\end{array}$ & $79 \%$ \\
\hline S-60 & $\begin{array}{l}1.5 \\
0 \\
\end{array}$ & $\begin{array}{l}2.0 \\
0 \\
\end{array}$ & $\begin{array}{l}1.0 \\
0 \\
\end{array}$ & $\begin{array}{l}2.0 \\
0 \\
\end{array}$ & 1.00 & $\begin{array}{l}2 . \\
00\end{array}$ & $\begin{array}{l}2.0 \\
0 \\
\end{array}$ & $\begin{array}{l}2.0 \\
0 \\
\end{array}$ & $\begin{array}{l}2.0 \\
0 \\
\end{array}$ & $\begin{array}{l}2.0 \\
0 \\
\end{array}$ & $\begin{array}{l}2.0 \\
0 \\
\end{array}$ & $\begin{array}{l}.0 \\
0 \\
\end{array}$ & $\begin{array}{l}2.0 \\
0 \\
\end{array}$ & 0.50 & $\begin{array}{l}24 . \\
00\end{array}$ & $86 \%$ \\
\hline S-61 & $\begin{array}{l}1.4 \\
4\end{array}$ & $\begin{array}{l}1.7 \\
8\end{array}$ & $\begin{array}{l}1.4 \\
4\end{array}$ & $\begin{array}{l}1.8 \\
9\end{array}$ & 1.11 & $\begin{array}{l}2 . \\
00\end{array}$ & $\begin{array}{l}1.1 \\
1\end{array}$ & $\begin{array}{l}2.0 \\
0\end{array}$ & $\begin{array}{l}2.0 \\
0\end{array}$ & $\begin{array}{l}2.0 \\
0\end{array}$ & $\begin{array}{l}2.0 \\
0\end{array}$ & $\begin{array}{l}2.0 \\
0\end{array}$ & $\begin{array}{l}2.0 \\
0\end{array}$ & 1.67 & $\begin{array}{l}24 . \\
44\end{array}$ & $87 \%$ \\
\hline $\begin{array}{l}\text { Averag } \\
\text { e }\end{array}$ & $\begin{array}{l}1.7 \\
2\end{array}$ & $\begin{array}{l}1.0 \\
2\end{array}$ & $\begin{array}{l}1.1 \\
6\end{array}$ & $\begin{array}{l}1.5 \\
0\end{array}$ & 1.03 & $\begin{array}{l}1 . \\
78\end{array}$ & $\begin{array}{l}1.8 \\
0\end{array}$ & $\begin{array}{l}1.8 \\
0\end{array}$ & $\begin{array}{l}1.9 \\
3\end{array}$ & $\begin{array}{l}1.9 \\
3\end{array}$ & $\begin{array}{l}2.0 \\
0\end{array}$ & $\begin{array}{l}1.8 \\
9\end{array}$ & $\begin{array}{l}1.7 \\
3\end{array}$ & 1.00 & $\begin{array}{l}22 . \\
26\end{array}$ & $80 \%$ \\
\hline
\end{tabular}

Annex 5:- The Questionnaire for Data Collection.

Testing of identified common criteria used by CPDS stakeholders to monitor and evaluate Pharmaceutical suppliers' performance.

Data Collection Tool.

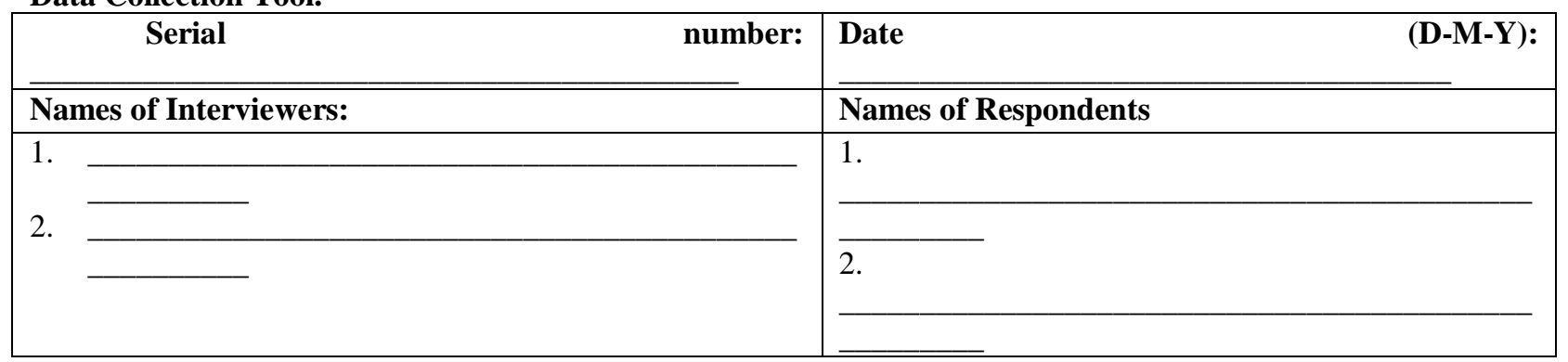

\section{Section A: Organization Background}

1. Name of the organization or department:

2. Type of the organization: (Please tick one that applies)
a. Government entity
b. International NGO (BPHS/EPHS implementers)
c. National NGO (BPHS/EPHS implementers)
d. Other: Please specify:

3. From where does your organization procure medicines: (Please circle one that applies)
a. Local market
b. International market
c. Both local and international markets 
4. Does your organization monitor suppliers' performance? a. Yes, b. No, c. Don't know

(If Yes, continue to respond the rest of the questions; if “No" or "Don't know", go to section B and continue)

5. If Yes, what is the monitoring interval?
a. Quarterly
b. Twice a year
c. Once a year
d. Irregular interval
e. Other Specify:

6. If Yes, is there any result of the monitoring or evaluation? (verify)

a. Score card

b. Report

c. Filled check list

interval.

d. Other. Specify:

Section B:- Identify suppliers' performance according to the proposed common criteria.

Please respond to the questions below for each supplier from which the organization procured pharmaceuticals in the last tender or regular purchase.

\begin{tabular}{|c|c|c|c|}
\hline 1. Supplier's name: & 2. Country of Origin & $\begin{array}{l}\text { 3. Type of purchase } \\
\text { from this supplier }\end{array}$ & $\begin{array}{l}\text { 4. Type of the supplier (Tick all } \\
\text { that apply) }\end{array}$ \\
\hline & $\begin{array}{l}\text { a. Afghanistan } \\
\text { b. Don't know }\end{array}$ & $\begin{array}{l}\text { a. Local } \\
\text { b. International }\end{array}$ & $\begin{array}{ll}\text { a. } & \text { Manufacturer } \\
\text { b. Importer } \\
\text { c. } \\
\text { d. } & \text { Rholesailer }\end{array}$ \\
\hline
\end{tabular}

\begin{tabular}{|c|c|c|c|c|c|}
\hline Criteria & $\begin{array}{l}\text { 5. Is the } \\
\text { criterion a } \\
\text { request in } \\
\text { the contract } \\
\text { terms? } \\
\text { (Verify) }\end{array}$ & $\begin{array}{l}\text { 6. Are there } \\
\text { documents } \\
\text { to verify the } \\
\text { criterion? } \\
\text { (Verify) }\end{array}$ & $\begin{array}{l}\text { 7. If yes, the } \\
\text { documents are: (in } \\
\text { paper or electronic } \\
\text { version) (Verify) }\end{array}$ & $\begin{array}{l}\text { 8. Did the } \\
\text { supplier meet the } \\
\text { criterion in the } \\
\text { last order of the } \\
\text { regular } \\
\text { purchase? } \\
\text { (Verify) }\end{array}$ & $\begin{array}{l}9 . \\
\text { Remarks }\end{array}$ \\
\hline \multicolumn{5}{|c|}{$\begin{array}{l}\text { \#1 Providing advance documents according to contract terms (Copies of supporting documents } \\
\text { such as licenses, GMP certificate, certificate of pharmaceutical product, bank security, certificate of } \\
\text { analysis, etc.) }\end{array}$} & \\
\hline $\begin{array}{l}\text { 1a. License (Afghanistan } \\
\text { or country of origin) }\end{array}$ & $\begin{array}{l}\text { a-Yes, b- } \\
\text { No, c-N/A }\end{array}$ & $\begin{array}{l}\text { a-Yes, b- } \\
\text { No, c-N/A }\end{array}$ & $\begin{array}{l}\text { a-paper , } \\
\text { electronic, c-N/A }\end{array}$ & \multirow{6}{*}{$\begin{array}{l}\text { a. Yes, fully met } \\
\text { b. Partly met } \\
\text { (Part) } \\
\text { c. No, didn't meet } \\
\text { d. Don't know } \\
\text { (Dk) }\end{array}$} & \\
\hline 1b. GMP certificate & $\begin{array}{l}\text { a-Yes, b- } \\
\text { No, c-N/A }\end{array}$ & $\begin{array}{l}\text { a-Yes, b- } \\
\text { No, c-N/A }\end{array}$ & $\begin{array}{l}\text { a-paper, } \\
\text { electronic, c-N/A }\end{array}$ & & \\
\hline $\begin{array}{l}\text { 1c. Certificate of } \\
\text { Pharmaceutical Product } \\
(\mathrm{COPP})\end{array}$ & $\begin{array}{l}\text { a-Yes, b- } \\
\text { No, c-N/A }\end{array}$ & $\begin{array}{l}\text { a-Yes, b- } \\
\text { No, c-N/A }\end{array}$ & $\begin{array}{l}\text { a-paper, } \\
\text { electronic, c-N/A }\end{array}$ & & \\
\hline 1d. Bank security & $\begin{array}{l}\text { a-Yes, b- } \\
\text { No, c-N/A }\end{array}$ & $\begin{array}{l}\text { a-Yes, b- } \\
\text { No, c-N/A }\end{array}$ & $\begin{array}{l}\text { a-paper, } \quad \text { b- } \\
\text { electronic, c-N/A }\end{array}$ & & \\
\hline 1e. Certificate of analysis & $\begin{array}{l}\text { a-Yes, b- } \\
\text { No, c-N/A }\end{array}$ & $\begin{array}{l}\text { a-Yes, b- } \\
\text { No, c-N/A }\end{array}$ & $\begin{array}{l}\text { a-paper, } \\
\text { electronic, c-N/A }\end{array}$ & & \\
\hline 1f. Other, specify: & $\begin{array}{l}\text { a-Yes, b- } \\
\text { No, c-N/A }\end{array}$ & $\begin{array}{l}\text { a-Yes, b- } \\
\text { No, c-N/A }\end{array}$ & $\begin{array}{l}\text { a-paper, } \\
\text { electronic, c-N/A }\end{array}$ & & \\
\hline \multicolumn{5}{|c|}{ \#2 Financial viability (ability to show audited financial statements) } & \\
\hline $\begin{array}{l}2-\quad \text { Audited financial } \\
\text { statements }\end{array}$ & $\begin{array}{l}\text { a-Yes, b- } \\
\text { No, c-N/A }\end{array}$ & $\begin{array}{l}\text { a-Yes, b- } \\
\text { No, c-N/A }\end{array}$ & $\begin{array}{l}\text { a-paper, } \\
\text { electronic, c-N/A }\end{array}$ & $\begin{array}{l}\text { a-Yes, b-Part, c- } \\
\text { No, d-Dk }\end{array}$ & \\
\hline \multicolumn{6}{|c|}{$\begin{array}{l}\text { \# } 3 \text { Qualification to tender or procurement (registered or licensed in country of origin or Afghanistan, WHO } \\
\text { prequalified, or GMP certificated) }\end{array}$} \\
\hline 3a. License-Afghanistan & $\begin{array}{l}\text { a-Yes, b- } \\
\text { No, c-N/A }\end{array}$ & $\begin{array}{l}\text { a-Yes, b- } \\
\text { No, c-N/A }\end{array}$ & $\begin{array}{l}\text { a-paper, } \\
\text { electronic, c-N/A }\end{array}$ & \multirow{3}{*}{$\begin{array}{l}\text { a. Yes, fully met } \\
\text { b. Partly met } \\
\text { (Part) } \\
\text { c. No, didn't meet } \\
\text { d. Don't know }\end{array}$} & \\
\hline $\begin{array}{l}\text { 3b. License-Country of } \\
\text { origin }\end{array}$ & $\begin{array}{l}\text { a-Yes, b- } \\
\text { No, c-N/A }\end{array}$ & $\begin{array}{l}\text { a-Yes, b- } \\
\text { No, c-N/A }\end{array}$ & $\begin{array}{l}\text { a-paper, } \\
\text { electronic, c-N/A }\end{array}$ & & \\
\hline $\begin{array}{l}\text { 3c. WHO pre-qualification } \\
\text { certificate }\end{array}$ & $\begin{array}{l}\text { a-Yes, b- } \\
\text { No, c-N/A }\end{array}$ & $\begin{array}{l}\text { a-Yes, b- } \\
\text { No, c-N/A }\end{array}$ & $\begin{array}{l}\text { a-paper, } \\
\text { electronic, c-N/A }\end{array}$ & & \\
\hline
\end{tabular}




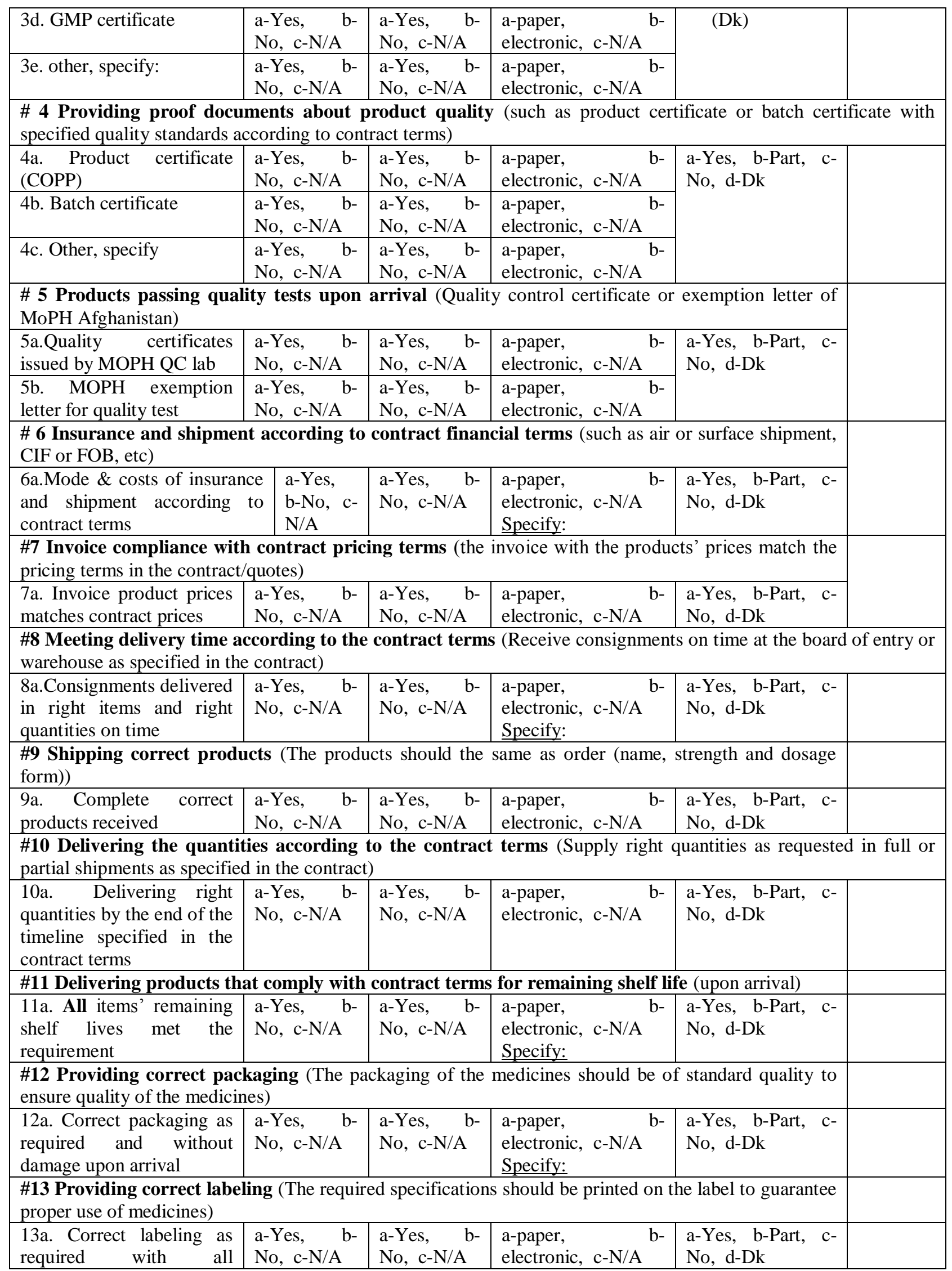




\begin{tabular}{|c|c|c|c|c|c|}
\hline recognizable information & & & Specify: & & \\
\hline \multicolumn{6}{|c|}{$\begin{array}{l}\text { \#14 Active update about order Status (To provide regular information regarding the status of } \\
\text { outstanding orders) }\end{array}$} \\
\hline $\begin{array}{l}\text { 14a. Provided updates } \\
\text { about the delivering status } \\
\text { of the outstanding orders }\end{array}$ & $\begin{array}{l}\text { a-Yes, b- } \\
\text { No, c-N/A }\end{array}$ & $\begin{array}{l}\text { a-Yes, b- } \\
\text { No, c-N/A }\end{array}$ & $\begin{array}{l}\text { a-paper, } \\
\text { electronic, c-N/A } \\
\text { Specify: }\end{array}$ & $\begin{array}{l}\text { a-Yes, b-Part, c- } \\
\text { No, d-Dk }\end{array}$ & \\
\hline
\end{tabular}

Annex 6:- The User Manual For Guiding Data Collection.

User Guide for the data collection tool for "Testing of identified common criteria used by CPDS stakeholders to monitor and evaluate pharmaceutical suppliers' performance"

\section{Background:-}

A set of common criteria for monitoring suppliers' performance was identified from BPHS/EPHS implementers and national hospitals in an earlier survey. This is the follow-on survey to use the common criteria for the objectives below:

- To identify the documents that are used for monitoring the suppliers performance by the organizations;

- To identify the suppliers that met the recommended criteria.

Instructions for administering the data collection tool:-

The data collection tool has three sections:

1. Basic information about the data collection including Serial Number, Date, names of the interviewers, and names of the respondents. (page 1)

2. Section A: organization background (Page 1)

3. Section B: Identify suppliers' performance according to the proposed common criteria (page 2-4)

Instructions for some key questions:-

1. Basic information about data collection including Serial Number, Date, names of the interviewers, and names of the respondents. (p. 1)

a. Serial Number: The serial numbers for the organizations will be assigned. A list of the organizations and their serial numbers will be given. Please fill the serial numbers accordingly.

b. Date: Please fill western date (dd-mm-2016)

2. Section A: organization background (Page 1): Organization's background regarding its procurement system.

a. Fill the organization's name followed by responding to Questions 2-4 in which only single answer would apply.

3. Section B: Identify suppliers' performance according to the proposed common criteria (page 2-4)

In this section, each supplier will be checked with 14 criteria. Please respond to the questions for each supplier from which the respondent's organization procured pharmaceuticals in the last tender or regular purchase. (Some organizations conduct open or restricted tenders for bulk purchase. Some conduct regular (such as quarterly) purchase with smaller amount than tenders). Emergency orders are not considered. 
A. Question 1-4: Supplier's name and type of the supplier.

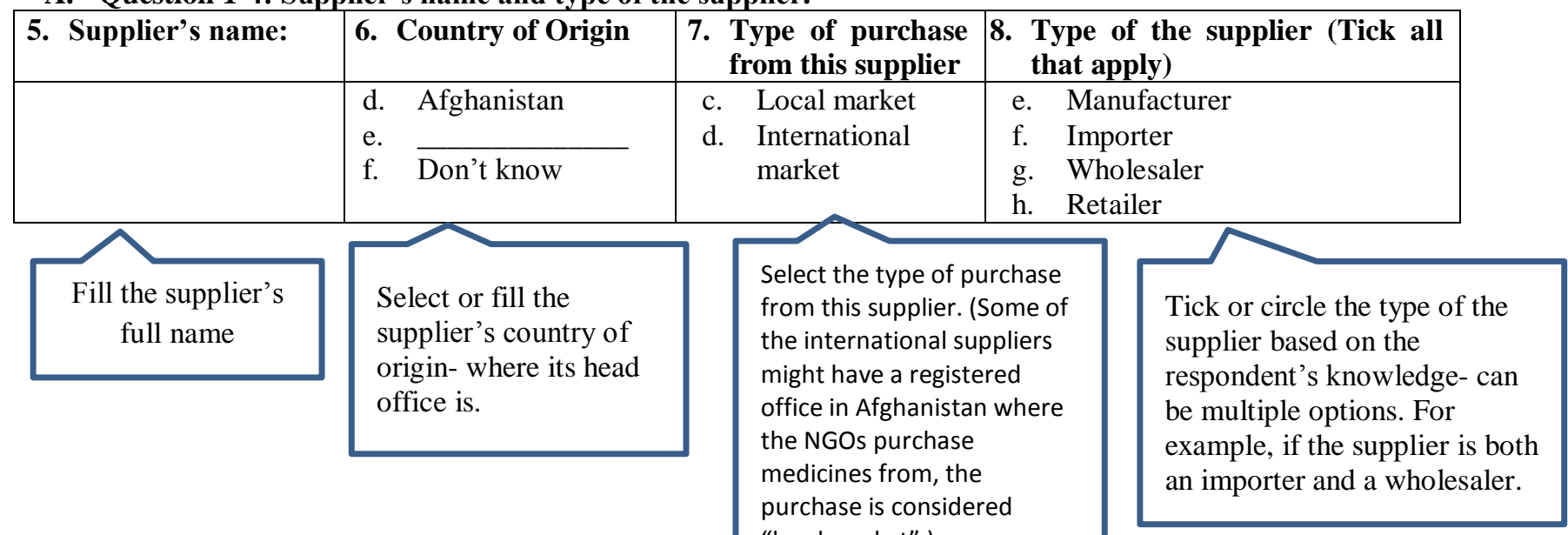

Question 5-8: The $2^{\text {nd }}$ table starting in page 2 lists the criteria for checking the supplier's performance:-

B1. General instructions for the heading:

\begin{tabular}{|c|c|c|c|c|c|}
\hline Criteria & $\begin{array}{l}\text { 5. Is the criterion a } \\
\text { request in the } \\
\text { contract terms? } \\
\text { (Verify) }\end{array}$ & 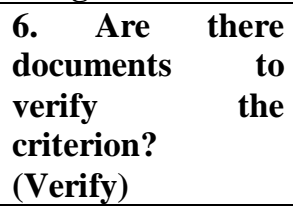 & $\begin{array}{l}\text { 7. If yes, the } \\
\text { documents are: } \\
\text { (based on the } \\
\text { original version) } \\
\text { (Verify) }\end{array}$ & $\begin{array}{l}\text { 8. Did the supplier } \\
\text { meet the criterion in } \\
\text { the last order of the } \\
\text { regular purchase? } \\
\text { (Verify) }\end{array}$ & $\begin{array}{l}9 . \\
\text { Remark } \\
\text { s }\end{array}$ \\
\hline & a-Yes, b-No, c-N/A & $\begin{array}{lll}\text { a-Yes, b-No, c- } \\
\text { N/A }\end{array}$ & $\begin{array}{l}\text { a-paper, } \\
\text { electronic, c-N/A }\end{array}$ & $\begin{array}{l}\text { a-Yes, b-Part, c-No, } \\
\text { d-Dk }\end{array}$ & \\
\hline
\end{tabular}

Note: Every question requires verification.

1. Q 5. Is the criterion a request in the contract terms? (Verify):-

a) Contract terms: the statements or requirements specified in the procurement contracts. In some small scale purchases, order letters might be used.

b) Check the procurement contract or order letter to verify if the criterion is a requirement in the contract/order letter (tick 'Yes', or 'No' accordingly). If there is no contract or order letter, tick 'c-N/A'.

c) If 'a-Yes', continue to Q6 to verify the required documents.

d) If 'b-No' or 'c-N/A', continue to Q6 to find out if any documents listed in each criterion available.

2. Q 6. Are there documents to verify the criterion? (Verify):-

a) Are there documents to verify the criterion: any documents listed or not which provide evidence for verifying the criterion. For example, license or product certificate for supplier and product qualification; invoice for pricing, deliver notes for product and quantities, delivery date; e-mail communications for updates, or any other records; etc.

b) If the criterion is specified in the contract terms, verify the documents and requirements according to the contract terms.

c) If there is no contract term or order letter, or the criterion is not requested in the contract terms or order letter (i.e. the answer to Q5 is "No" or N/A"), there may be documents that can be used to track the supplier's performance.

d) If the answer to Q6 is ' $a-Y e s$ ', proceed to verify Q7. If the answer to Q6 is 'b-No' or 'c-N/A', then answer c-'N/A' to Q7. 
3. Q 7. If yes, the documents are: (based on the original version) (Verify)

a) Some of the documents are listed in the criteria, such as \#1-\#5 and \#7. Verify if they are in paper or electronic.

b) Some of them are not listed and require specification, such as \#6, \#8, \#11-\#14. Please verify if they are in paper or electronic, and specify the name of the documents. For example, delivery note, mails, or e-mails, etc.

a-paper, b-electronic, c-N/A

Specify:

c) If the answer to Q6 is 'a-Yes', verify the format or specification of the documents in Q7. If answer 'a-Yes' to Q6 but 'c-N/A' to Q7, please explain in the "Remarks" column.

d) If the answer to $\mathrm{Q} 6$ is 'b-No' or 'c-N/A', then answer c-'N/A' to $\mathrm{Q} 7$.

4. Q 8. Did the supplier meet the criterion in the last order of the regular purchase? (Verify)

a) Some of the criteria can be verified according to the required documents in the contract terms (such as \#1$5, \& \# 7$ ); some of them need to be verified through checking the contents in the supporting documents such as invoices or delivery notes.

b) The instructions about how to verify whether the supplier meet the criterion are provided in the next section.

\section{Q 9. Remarks}

a) Any important extra information or explanation the respondent provided, or any significant issues or problems that the data collectors encountered can be recorded in the Remarks.

b) The information in the Remarks will be used to understand any limitations or challenges.

\section{B 2. Instructions for the criteria:-}

Criteria 1-5:- Verify the result according to the documents requested in the contract terms or official letter.

\#1 Providing advance documents according to contract terms (Copies of supporting documents such as licenses, GMP certificate, certificate of pharmaceutical product, bank security, certificate of analysis, etc.)

\#2 Financial viability (ability to show audited financial statements)

\#3 Qualification to tender or procurement (registered or licensed in country of origin or Afghanistan, WHO prequalified, or GMP certificated)

\#4 Providing proof documents about product quality (such as product certificate or batch certificate with specified quality standards according to contract terms)

\#5 Products passing quality tests upon arrival (Quality control certificate or exemption letter of MoPH Afghanistan)

1. Check what documents are requested by the organization in the contract or any order letter that the supplier should provide. There are several documents listed in these questions with an open option (other, specify). However, only those requested by the organizations count (those 'a-Yes' to Q5). If the answer to Q5 is 'bNo' for a document, then do not need to consider it (Q6-Q7: 'c-N/A').

2. To answer $\mathbf{Q 8}$ (Did the supplier meet the criterion in the last order of the regular purchase?):

a. If all the documents requested in the contract or any official order letter ('a-Yes' to Q5) are available ('aYes' to Q6, and 'a' or 'b' to Q7), tick 'a-Yes' for Q8.

b. If some of them available ('a-Yes' to Q5, but some of them 'c-No' to Q6), tick 'b-part' for Q8.

c. If none of them are available:

- If answer 'c-No' to Q6, tick 'c-No' for Q8.

- If answer 'a-Yes' to Q5, but all of them are 'c-No' to Q6, tick 'd-DK' for Q8.

d. If all the answers to $\mathrm{Q} 6$ is ' $\mathrm{c}-\mathrm{N} / \mathrm{A}$ ', tick ' $\mathrm{d}-\mathrm{DK}$ ' for $\mathrm{Q} 8$.

Criteria 6-14:- Verify the result according to the contents of the supporting documents or standards required in the contract terms or official order letter.

\# 6 Insurance and shipment according to contract financial terms (such as air or surface shipment, CIF or FOB, etc) \#7 Invoice compliance with contract pricing terms (the invoice with the products' prices match the pricing terms in the contract/quotes) 
1. \#6 and \#7 can be verified through comparing the contract or order letter with agreed quotations against invoices or any documents that have the final, delivered medicine prices and insurance/shipment costs. There may be several invoices for one purchase.

2. To answer Q8 (Did the supplier meet the criterion in the last order of the regular purchase?): verify the prices in the invoices if they were the same as specified in the contract or agreed quotations. The data collectors may ask the respondent to identify the items that were not compliant with the requirement, or verify them by the data collectors themselves. If all prices matched the requirements, tick 'a-Yes'; if some of them did not match, tick 'b-Yes, Part', if none of them matched, tick 'c-No', if there is no evidence for verification, tick 'd-Dk'.

\#8 Meeting delivery time according to the contract terms (Receive consignments on time at the board of entry or warehouse as specified in the contract)

\#9 Shipping correct products (The products should the same as order (name, strength and dosage form))

\#10 Delivering the quantities according to the contract terms (Supply right quantities as requested in full or partial shipments as specified in the contract)

\#11 Delivering products that comply with contract terms for remaining shelf life (upon arrival)

3. \#8-\#11 can be verified through comparing the contract or order letter with agreed quotations against delivery notes. There may be several delivery notes for one purchase.

4. \#8: delivering time: The requirements in the contract could be the dates of "delivering" "arrival" or "receiving". The delivery notes normally have delivering date (printed by the supplier) and receiving date (signed by the receiving staff). An acceptable time period for delivering or receiving may be specified for full shipment or partial shipments, depending on the contract or the agreement. Ask the respondents if there were any delays in delivering the products. Verify the dates between the contract and the delivery notes to answer Q8 (if the last delivery note shows that the deliveries meet the deadline specified in the contract).

5. \#9 and \#10: delivering right products and quantities: These are the main contents in the delivery notes. Ask the respondents if there were any items that were supplied in wrong product specifications or wrong quantities. Verify the contract against the delivery notes to answer Q8. (If there were any agreed changes about products or quantities after the contract was issued, check the revised document (contract or order) regarding products and quantities to verify the results.)

6. \#11: remaining shelf life: Some contracts specify the products' remaining shelf life upon arrival at the board of entry (international purchase) or at the warehouse (local purchase).

- Some delivery notes indicate the products' expiry dates so that the buyer can verify the "remaining shelf lives" of the products while receiving the consignments. To answer Q8: Use the formula: The earliest expiry date $=$ Receiving date $($ month $)+$ required minimum remaining shelf life. For example: If the required remaining shelf life specified in the contract is 18 months, check the date of receiving and the products' expiry dates on the delivery notes. If the receiving date signed in the delivery note is Jun 2014, the products' earliest expiry date should be Dec 2015 (June 2014+ 18 months), i.e. all the products' expiry dates should be later than Dec 2015. Check the expiry dates in the delivery note, if all the products expiry dates are later than Dec 2015, answer: 'a-Yes'. If some of their expiry dates are earlier than Dec 2015, answer: 'b-Part'. If all of them are earlier than Dec 2015, answer: 'c-No'.

- Some delivery notes do not include products' expiry dates, the buyer has to physically check the products' expiry dates after receiving. To answer Q8, if the respondent can provide the document with the expiry dates for that purchase, use the formula above to verify the result. If there is no document or evidence for verification, answer ' $\mathrm{d}-\mathrm{Dk}$ '.

\#12 Providing correct packaging (The packaging of the medicines should be of standard quality to ensure quality of the medicines)

\#13 Providing correct labeling (The required specification should be printed on the label to guarantee proper use of medicines)

7. \#12 - \#13 (packaging and labeling): Some contracts may require special packaging for certain items, but not general packaging and labeling. Most delivery notes do not have information about packaging and labeling. Sometimes cold chain or other special packaging medicines may be in separate delivery notes. 
- Regarding packaging requirement, the medicines that require special packaging (such as temperaturesensitive medicines, or fragile items) are most likely to be specified in the contract. The general principle for acceptable packaging is "the consignments arrive without any damage".

- Regarding labeling requirement, the language, special warnings, or the template of expiry date might be specified in some contracts. The principle for general labeling is "the information on the label is all recognizable".

8. \#12: To answer Q8: Check the contract or order letter if there is any specific packaging requirement (answer 'aYes', or 'b-No' for Q5 accordingly), and if the respondent could present any evidence about whether the supplier adhere to the requirements in order to answer Q6 \& Q7. If there is no document to verify for Q8, ask the respondent if the consignments received for the last tender or regular purchase were well packed without any damage. If All were packed well without damage, answer 'a-Yes'; if some package were damaged, answer 'b-Part'; if the respondent doesn't know the packaging condition, answer 'd-Dk'.

9. \#13: to answer Q8: Check the contract or order letter if there is any specific labeling requirement (answer 'aYes', or 'b-No' for Q5 accordingly), and if the respondent could present any evidence about whether the supplier adhere to the requirements in order to answer Q6 \& Q7. If there is no document to verify for Q8, ask the respondent if the consignments received for the last tender or regular purchase were well labeled with all the information recognizable. If All were labeled correctly, answer 'a-Yes'; if some labels were torn or unrecognizable, answer 'b-Yes, Part'; if the respondent doesn't know the labeling condition, answer 'd-Dk'.

\#14 Active update about order Status (To actively provide regular information regarding the status of outstanding orders)

10. \#14 (active update and communication): This is unlikely to be required in the contract or order letter. However, verify it from the contract or order letter before answering Q5. To answer Q6-Q7, check if there are any communication e-mails or records.

11. \#14: To answer Q8, if the above communication records are available and verifiable, answer 'a-Yes'. If there is no communication record but there were communications (such as phone calls), ask the respondent if the suppliers always actively gives updates, answer $\mathbf{Q 8}$ in following potential situations:

- Respond "Yes, always", tick 'a-Yes'

- Respond "sometimes", or "they respond immediately only when we follow up the delivery status for the orders", tick 'b-Yes, Part'.

- Respond "No, they don't update about order status at all", or "they don't respond or they respond very late when we ask for order status", tick 'c-No'.

- Respond "I don't know" or any response that the interviewer could not verify, tick 'd-Dk'.

\section{References:-}

1. Abdolshah, M., 2013. A Review of Quality Criteria Supporting Supplier Selection. Journal of Quality and Reliability Engineering.

2. CA, D., 2008. Department of General Services, CA. Supplier Performance Report, s.1.: s.n.

3. Cormican, K. \& Cunningham, M., 2007. Supplier performance evaluation: lessons from a large multinational organisation (abstract). Journal of Manufacturing Technology Management, 18(4), pp. 352-366.

4. Enyinda, C. I., Emeka, D. \& Bell-Hanyes, J., 2010. A model for quantifying strategic supplier selection: Evidence from a generic pharmaceutical firm supply chain. International Journal of Business, Marketing, and Decision Sciences, 3(2), pp. 25-44.

5. Gordon, S., 2005. Seven Steps to measure supplier performance. http://spce.ac.uk/wp-content/uploads/1805.pdf.

6. Harton, S., 2004. Creating and using suppliers' scorecards, s.1.: Contract Management.

7. Lindsey, M., n.d. Supplier Performance Ratings - Scorecards, Rankings, and Awarding Business, s.1.: s.n.

8. Liu, Y., n.d. A Case Study of Evaluating Supplier's Selection Criteria in a Steel Bars Manufacturer. [Online] Available at: [Accessed 30 April 2015].

9. MoPH_GDPA, 2010. Coordinated Procurement and Distribution System (CPDS) Governance Framework. s.l.:s.n.

10. NC, D., 2013. North Carolina Department of Administration. Contractor/Supplier Performance Evaluation Report. Version 2.. [Online] Available at: http://www.doa.nc.gov/pandc/Documents/Contract-Administrationand-Monitoring-Guide/Contractor-SupplierPerformanceEvaluationRepo [Accessed 6 May 2015]. 
11. Ongeri, B., 2013. Technical Report of Supplier Performance Monitoring for 2012 at Central medical Store, Namibia. Submitted to the US Agency for International Development by the Supply Chain Management System (SCMS), s.l.: s.n.

12. Pal, O., Gupta, A. K. \& Garg, R., 2013. Supplier Selection Criteria and Methods in Supply Chains: A Review. International Journal of Social, Education, Economics and Management Engineering, 7(10), pp. 1395-1401.

13. PQG, 2010. A Guide to Supply Chain Risk Management for the Pharmaceutical and Medical Device Industries and their Suppliers. Pharmaceutical Quality Group. [Online] Available at: http://www.pqg.org/pharma/wpcontent/uploads/2011/09/PQG-Guide-to-Supply-Chain-Risk-Management-V-1-0-2 [Accessed 122014 ].

14. Salama, H., 2005. The importance of supplier management-A sponsor's perspective on achieving operational success. Contract Pharma, 23 August.

15. Suárez Bello, M. J., 2003. A case study approach to the supplier selection process, s.1.: A project submitted in partial fulfillment of the requirements for the degree of Master of Engineering in Management Systems Engineering at the University of Puerto Rico Mayagüez Campus.

16. University of Exeter, n.d. Procurement Manual: Good Practice 4. Assessing Supplier performance, s.l.: s.n.

17. WHO/WPRO, 2002. Practical Guidelines on Pharmaceutical Procurement for Countries with Small Procurement Agencies.

18. WHO, 1999. Operational principles for good pharmaceutical procurement.

19. WHO, 2010. WHO good distribution practices for pharmaceutical products, s.1.: s.n. 